UNIVERSIDADE DE SÃO PAULO

FACULDADE DE FILOSOFIA, LETRAS E CIÊNCIAS HUMANAS

DEPARTAMENTO DE LETRAS CLÁSSICAS E VERNÁCULAS

PROGRAMA DE PÓS-GRADUAÇÃO EM LITERATURA BRASILEIRA

\title{
SIM E NÃO - O RITMO BINÁRIO \\ em A Paixão segundo G.H., de Clarice Lispector
}

Tony Monti

Dissertação de Mestrado apresentada ao Programa de Pós-Graduação em Literatura Brasileira do Departamento de Letras Clássicas e Vernáculas para obtenção do título de Mestre em Literatura Brasileira.

Orientador: Prof. Dr. Valentim Aparecido Facioli

São Paulo

2005 
"E os outros? Os outros não estão dentro de mim. Para os outros, que observam de fora, as minhas idéias, os meus sentimentos, têm um nariz. O meu nariz. E têm um par de olhos, os meus olhos, que eu não vejo e eles vêem. Que relação existe entre as minhas idéias e o meu nariz? Para mim, nenhuma. Eu não penso com o nariz nem, pensando, reparo no meu nariz. E os outros? Os outros, que não podem ver dentro de mim as minhas idéias e que vêem, de fora, o meu nariz? Para os outros, as minhas idéias e o meu nariz têm tanta relação, que, se aquelas, suponhamos, fossem muito sérias e este, pela sua forma, fosse muito ridículo, desatariam a rir." - Luigi Pirandello -

"Não se trata de ouvir uma série de frases que enunciam algo; o que importa é acompanhar a marcha de um mostrar."

- Martin Heidegger -

“90\% do que eu escrevo é mentira. O resto eu invento." - Manoel de Barros - 
Aos meus pais, Rosa e Fernando, e irmãos, Cely e Alex, que me deram o chão.

Ao Abilio e ao Zé Medeiros, pelas táticas e estratégias compartilhadas.

À Maíra, que me tirou o chão.

Ao Valentim, pela acolhida. 


\section{ÍNDICE}

Resumo 4

Abstract 5

$\begin{array}{ll}\text { Introdução para romper o silêncio } & 6\end{array}$

I. O impasse como força motriz do texto $\quad 8$

1. Três descaminhos ideais - ordem, beleza e limpeza 8

Desorganizar - um primeiro olhar sobre o texto 9

$\begin{array}{ll}\text { Sujeira - mais alguns espasmos } & 21\end{array}$

Beleza - a proposta de eliminação da mediação estética 30

2. Aqui e ali $\quad 37$

II. Compasso binário $\quad 47$

III. Páthos e liberdade 83

Considerações finais antes do silêncio 106

Bibliografia

De Clarice Lispector $\quad 108$

Sobre Clarice Lispector $\quad 108$

$\begin{array}{ll}\text { Geral } & 109\end{array}$ 


\section{RESUMO}

Esta dissertação é uma leitura de A Paixão segundo G.H., de Clarice Lispector. Tem como foco a questão da liberdade do homem no mundo e de suas possibilidades de dizer, como tratadas no romance. Aproxima-se em diversos aspectos da crítica de Benedito Nunes à obra da escritora, no que diz respeito à identificação e às diferenças entre Clarice e o existencialismo de Sartre. Uma idéia de ritmo binário é formulada, sucessão de afirmações e negações, que dá cadência ao texto e o estrutura. Os dois tempos desse ritmo são relacionados a duas idéias diferentes de liberdade, (1) a de poder (e ser obrigado a) escolher e (2) a de não ser obrigado a (nem poder) escolher. Formuladas como características de dimensões diferentes do ser humano, as duas vias que tais liberdades abrem não podem ser sintetizadas numa única.

\section{PALAVRAS-CHAVE}

Clarice Lispector, Literatura Brasileira, Romance Brasileiro, Existencialismo, Liberdade 


\begin{abstract}
This dissertation is about Clarice Lispector's A Paixão Segundo G.H. Its main focus is on the issue of mankind's freedom and its possibilities of saying, as dealt with in the novel. In many respects, it is close to Benedito Nunes' viewpoint in what regards the similarities and differences between Clarice Lispector and the Sartrean existentialism. A sense of binary rhythm is built, sequence of statements and negatives, which structures the text and gives it a cadence. This rhythm's two tempos are related to two different ideas about freedom. First, the sense of being able (having to/being forced to) choose and, second, of not being forced to (or being able to) choose. Enounced as characteristics of human beings' different dimensions, the two paths opened up by these senses of freedom cannot be merged into a single whole.
\end{abstract}

\title{
KEYWORDS
}

Clarice Lispector, Brazilian Literature, Brazilian Novel, Existentialism, Freedom 


\section{Introdução para romper o silêncio}

A complexidade de A Paixão segundo G.H. nunca me abriu uma porta única para entrar. À minha primeira leitura, há não muitos anos, porta alguma foi aberta, nenhuma que eu conseguisse definir sem dúvida como porta. Duas ou três leituras depois, tantas portas tinham sido abertas que eu não sabia por qual delas entrar. $\mathrm{Na}$ indecisão, percebi todas elas se fechando de novo antes que eu entrasse. Depois de um tempo, portas abertas de novo, comecei a entrar sem escolher demais. A alternância entre nenhuma e muitas portas ainda não parou. Às vezes o livro me faz sentido nenhum, às vezes tanto(s) sentido(s) que tudo me parece óbvio a ponto de nem merecer ser expresso.

No processo de tomar nota (inicialmente) e escrever a dissertação (ultimamente), cada idéia de interpretação deformou a anterior. Cada nova leitura e cada nova reflexão me exigiram repensar tudo. Cada mudança na maneira como eu organizo, para mim, o livro, pede a retomada de toda mínima fração das idéias que guardo sobre ele.

A organização deste texto final da dissertação é o retrato de um percurso. A princípio, sem saber por que porta entrar, elegi três - ordem, limpeza e beleza - sem a preocupação, ainda, de sistematizar qualquer coisa. Essa primeira aproximação resultou no primeiro capítulo. Da análise da idéia de beleza, fui levado a pensar em como Clarice estrutura seu romance, ainda nesse capítulo. Agora, algum tempo depois, essas primeiras páginas me soam mais ligadas a uma tentativa de se fazer sujeito, a uma crença em um tipo de liberdade que me norteou e que eu reconheci no romance.

Quando terminei a redação desse capítulo, descobri que ele funcionava para mim como paráfrase do texto, e que eu precisava, então, sistematizar algumas idéias. O segundo capítulo é essa tentativa de reorganizar o livro passando por elementos que estruturam sua construção - como se dão as relações temporais e causais, como se relacionam sujeito e mundo, enunciador, texto e recepção. Listei também uma pequena série de procedimentos que dão ao romance determinado ritmo, que determinam a marcha do texto em seus grandes e em seus pequenos elementos. Nesse capítulo, as duas maneiras de entender liberdade no texto - possibilidade de escolher e não obrigação de escolher - estão mais balanceadas e associadas ao ritmo binário, afirmação seguida de negação. 
Por fim, no terceiro capítulo, arrisquei um olhar mais leve sobre as questões da linguagem e da liberdade, aproximando meus pontos de vista dos do crítico Benedito Nunes, e o texto de Clarice dos de Sartre, fazendo as devidas distinções.

Texto escrito, flagrei-me mudando a terminologia, adicionando notas e parênteses a fim de amolecer as afirmações que parecessem certas demais. Sinto que cada linha poderia ser melhor escrita. Tentei tantas vezes guardar distância do texto de A Paixão segundo G.H. ... penso às vezes que, é possível, se tentasse por muito tempo ainda melhorar as linhas desse trabalho, acabaria, como Pierre Menard que escreveu o Quixote, escrevendo $A$ Paixão. 


\section{CAPÍTULO I \\ O IMPASSE COMO FORÇA MOTRIZ DO TEXTO}

\section{1 - Três descaminhos ideais - ordem, beleza e limpeza}

No centro das discussões de G.H., tanto como personagem envolvida na experiência narrada quanto como narradora dos fatos, está a contraposição entre dois pólos, figurados no livro de uma infinidade de maneiras. O primeiro pólo - ligado a palavra, a forma, a valores e a significados - chamaremos, para iniciar as discussões, de moral. O segundo - o pólo da existência não significada nem avaliada, do informe, do incontido, do orgânico - será chamado, a princípio, de neutro.

No percurso narrativo, Moral se identifica, por exemplo, com valores ideais, tais como beleza, limpeza e ordem. Tais valores são desafiados pela força de uma existência contingente que toma a personagem G.H. e relativiza significados e formas pré-concebidas. Em A Paixão Segundo G.H. ${ }^{l}$, o conflito é expresso pela incongruência entre os valores e significados de G.H. antes do seu encontro com a barata, pelos novos valores e significados, após a experiência, e pelo caos destituído de valores durante a experiência. A consciência da personagem reconhece parcelas de si e do mundo inconciliáveis com seus valores e significados, ou, talvez, com quaisquer valores e significados. O enunciado de G.H. narradora é uma tentativa de dar uma forma ao informe que a incomoda e se livrar do desconforto da falta de sentido de sua experiência.

Uma primeira leitura do depoimento de G.H. pode levar à suspeita de que sua experiência com a barata (episódio em torno do qual se organizam as tensões narrativas) seria esclarecedora e (re)ordenadora, o que faria com que moral/não-moral devessem se arranjar em função dos tempos (antes, depois e durante) da experiência. No entanto, essas relações temporais não se formam de um modo a isolar o neutro e acomodá-lo em palavra num período separado dos demais, justamente por de palavra não se tratar. A passagem de um estado a outro não se dá de maneira definitiva, não sendo possível traçar uma evolução que não possa ser questionada. Um estado não supera com segurança um estado anterior, o

\footnotetext{
${ }_{1}^{1}$ PSGH - Lispector, C. A Paixão segundo G.H. Rio de Janeiro: Rocco, 1998.
} 
que faz da passagem do tempo, linear, conforme o texto é lido, uma dimensão diferente do tempo que se enrola em si, supera e volta, constrói e desconstrói. ${ }^{2}$ Ainda, como o texto se diz e se nega, torna-se difícil dizer o quanto são diferentes os estados de antes e depois da experiência.

A fim de percorrer A Paixão segundo G.H., levantar questões e fazer a primeira aproximação ao caos da experiência que o texto se propõe retratar, escolheu-se analisar o modo como se dá a relação de G.H. com os três conceitos - ordem, limpeza e beleza - e investigar como essa relação se modifica ao longo do texto e de acordo com a situação construída pela autora. Acompanhar o percurso da narrativa pelo ponto de vista de cada uma dessas dimensões morais é verificar a medida em que cada uma dessas dimensões é desconstruída como um aspecto da desconstrução da moral como um todo. Ainda, essa tentativa de desconstrução vale como amostragem da dificuldade (se não impossibilidade) de G.H. para dizer o neutro, para superar o incômodo da experiência e para organizar qualquer coisa sem que questione a organização a ponto de se paralisar. Ao contrário, toda a estrutura interna da narrativa se estabelece acompanhada pelo impasse, que tende a impedir os movimentos e as superações. Os sucessos locais são sempre contestáveis quando dispostos numa escala de espaço ou de tempo mais abrangente ou quando da mudança dos pontos de vista.

\section{Desorganizar - um primeiro olhar sobre o texto}

Dos três valores ideais escolhidos para acompanhar o percurso de G.H., ordem é o mais abrangente. Não é difícil relacioná-lo a limpeza e a beleza. Se tudo estiver em seu devido lugar, segundo algum princípio de ordenação, pode-se dizer que há ordem e, por derivação, também limpeza. Do mesmo modo, certas relações de simetria, certas combinações de cores e de formas são sempre relacionados a beleza (ou a algum conceito de beleza). Assim, ordem é o conceito ideal abrangente que se opõe ao caos, que corresponde ao mundo orgânico não avaliado.

\footnotetext{
${ }^{2}$ Pode-se dizer que há três grandes momentos no percurso da personagem: (1) G.H. antes da experiência, (2) G.H. durante a experiência e (3) G.H. após a experiência. As coisas se complicam se considerarmos o fato de que em muitos momentos o tempo do narrador (3) e o da narrativa (2) se confundem. Além disso, tanto em (2) quanto em (3) há movimento, evolução, retrocesso e questionamento na apreensão e na reflexão sobre a experiência.
} 
Desde a primeira linha de PSGH, há passagens que podem ilustrar a oposição ordem/caos, tensão central da obra e ligada a moral/neutro. Logo no primeiro parágrafo do livro:

\begin{abstract}
Não sei o que fazer do que vivi, tenho medo dessa desorganização profunda. Não confio no que me aconteceu. Aconteceu-me alguma coisa que eu, pelo fato de não saber como viver, vivi uma outra? A isso queria chamar desorganização, e teria a segurança de me aventurar, porque saberia depois para onde voltar: para a organização anterior. (PSGH, 11)
\end{abstract}

A narrativa começa e ordem e moral já estão associadas. Do mesmo modo, caos e neutro. A princípio, G.H. tende a relacionar também, inequivocamente, moral a sua vida anterior à experiência, e neutro ao núcleo vivo do seu encontro com a barata. Em questionamentos posteriores, no entanto, G.H. relativizará as possibilidades de separação dos dois pólos. A G.H. posterior à experiência é a que tenta fazer o difícil balanço entre os componentes opostos.

Para a minha anterior moralidade profunda - minha moralidade era o desejo de entender e, como eu não entendia, eu arrumava as coisas, foi só ontem e agora descobri que sempre fora profundamente moral: eu só admitia a finalidade - para a minha profunda moralidade anterior, eu ter descoberto que estou tão cruamente viva quanto essa crua luz que ontem aprendi, para aquela minha moralidade, a glória dura de estar viva é um horror. (PSGH, 22)

Assim, ordem e moral associadas, G.H. apresenta-se com certa compulsão para a organização, derivada de seus bem delimitados princípios morais - "profundamente moral". Tal disposição a organizar torna-se incompatível com a reflexão desencadeada pela experiência vivida, e faz do caos, vislumbrado a partir do encontro com a barata, um terror que se transfigura em medo. Por sua vez, medo se opõe a coragem, necessária para incluir o caos no rol de valores e significados do indivíduo, em vez de ignorá-lo ou enquadrá-lo nos moldes pré-estabelecidos pela moral já internalizada. Em outras palavras, G.H. se encontra frente a um dilema: (1) jogar fora toda a recente experiência, (2) fragmentá-la e 
distribuí-la pelos moldes antes existentes, o que seria o mesmo que destruí-la ou (3) assimilá-la em novos moldes, o que exigiria que novos valores fossem criados, que alguns dos antigos fossem destruídos e, num segundo plano, um princípio destruidor fosse incluído na sua moral, que assim seria menos rígida, disposta a constantes atualizações. Essas três possibilidades, em termos dialéticos, são manifestações de (1) não aceitar a antítese ao modo moral inicial, permanecendo num ponto que será tese, no caso de a tensão poder ser entendida como um par dialético; (2) descartar a antítese por conformá-la nos moldes pré-estabelecidos pela tese; (3a) conseguir a síntese entre a moralidade anterior (tese) e a experiência com a barata e suas derivações (antítese). Ainda, é possível que (3b) tese e antítese convivam na G.H. posterior à experiência sem que um modo sintético seja estabelecido. Essa é a primeira busca em PSGH em relação a suas possibilidades como texto: a tentativa de desconstrução da moral anterior de G.H. (excessivamente rígida) como meio de assimilar a experiência.

Uma imagem forte dessa estrutura é o ser humano com três pernas, modo pelo qual a narradora descreve sua existência anterior ao encontro com a barata. É humano um ser humano de três pernas? Segundo G.H., excessivamente humano (ou, na transposição da imagem para o campo dos valores, excessivamente moral). Expressa assim na imagem grotesca, a estrutura dialética inicial, que pode levar da moral anterior a uma moral posterior diferente, é, não só o retrato de uma possibilidade, uma proposta para fazer do humano apenas humano.

Perdi alguma coisa que me era essencial, o que já não é mais. Não me é necessária, assim como se eu tivesse perdido uma terceira perna que até então me impossibilitava de andar mas que fazia de mim um tripé estável.

Essa terceira perna eu perdi. E voltei a ser uma pessoa que nunca fui. Voltei a ter o que nunca tive: apenas duas pernas. Sei que somente com duas pernas é que posso caminhar. Mas a ausência inútil da terceira me faz falta e me assusta, era ela que fazia de mim uma coisa encontrável por mim mesma, e sem sequer precisar me procurar. (PSGH, 11-12)

Desse modo, a G.H. anterior é apresentada como um equilíbrio hiperestático, em que os sustentáculos do equilíbrio, as três pernas, são em número maior do que o mínimo 
necessário. A G.H. posterior, no entanto, com apenas duas pernas, seria um equilíbrio isostático, e qualquer esforço adicional sobre ela faria com que ela se movimentasse. Por outro lado, a diminuição da rigidez no equilíbrio, embora dê menos sustentação a cada posição, pode ser encarada como maior liberdade. Mais uma vez, o jogo entre coragem e medo aparece. A coragem relaciona-se ao caos, é condição necessária para enfrentá-lo sem, precipitadamente, se render à forma fácil e aprisionar o caos em moldes rígidos e préconcebidos. Relaciona-se também à liberdade de caminhar com apenas duas pernas. No entanto, essa mesma liberdade é contestada na seqüência do texto.

Mas e agora? estarei mais livre?

Não. (PSGH, 12)

Esta não-liberdade que G.H. atribui a si parece ser resultado da nova ordem, que embora menos rígida (apenas duas pernas), ainda é ordem. Quando se está no pólo da ordem, torna-se difícil vislumbrar o pólo oposto, que não cabe nas categorias dessa organização, ou de organização alguma. O que faz, no caso de G.H., com que uma ordem se diferencie qualitativamente da outra é a coragem, a disposição para deixar a ordem e perder-se, o que pode ser entendido como a disponibilidade que a moral deve ter para incluir a possibilidade de ser insuficiente ou inadequada. Enquanto G.H. continua tentando enquadrar a experiência em formatos pré-determinados sem a disposição de descartar tais formatos, a liberdade não se apresenta, e a organização de G.H. não difere significativamente da que ela utilizava antes de sua experiência. Nesse início de texto, a personagem oscila ainda entre a moral rígida antiga e a possibilidade de uma nova moral, mais flexível, enquanto o novo princípio organizador (Moral) vai sendo formado (e deformado) ao longo de suas reflexões. Ainda regida pela moral rígida anterior, apenas ordem (bem) e desordem (mal) dissociadas podem ser reconhecidas. Pela estrutura moral anterior, não é possível uma ordem que aceite a possibilidade da desordem em seus próprios princípios. (Mesmo porque o princípio moral anterior se vê como capaz e, assim, não vê a necessidade de uma moral que não seja ele mesmo). Ainda, um novo sistema moral é uma proposta, não (ao menos por enquanto) algo estabelecido, para conseguir formalizar a experiência heterodoxa com a barata. Não é garantido, a princípio, que a 
disposição para mudar e flexibilizar valores e significados dê resultado satisfatório logo que se configure e tente se estabelecer.

Contrário à coragem, o medo associa-se à paralisação, ao excesso de segurança, às três pernas e à ordem excessiva, talvez desnecessária.

Estou desorganizada porque perdi o que não precisava? Nesta minha nova covardia - a covardia é o que de mais novo me aconteceu, é a minha maior aventura, essa minha covardia é um campo tão amplo que só a grande coragem me leva a aceitá-la -, na minha nova covardia, que é como acordar de manhã na casa de um estrangeiro, não sei se terei coragem de simplesmente ir. É difícil perder-se. É tão difícil que provavelmente arrumarei depressa um modo de me achar, mesmo que achar-me seja de novo a mentira de que vivo. (PSGH, 12)

Por medo ("covardia") em relação à nova descoberta - a desorganização -, G.H. suspeita que logo encontrará uma nova organização, e a isso dá o nome de "mentira". Embora não se explicite, no trecho acima, por contraste é possível inferir que o pólo da desordem, neutro, relaciona-se com verdade. E que as diferentes ordens possíveis seriam diferentes mentiras. Se a nova ordem incluir em si a disposição para mudar (coragem), será significativamente diferente da anterior. Se não, será mais um sistema rígido de valores. Reforça-se assim a proposta de que se deixe o excesso de moral (organização), agora chamado de "mentira", e que, por decorrência, aproxime-se do pólo neutro, "verdade". Uma complicação, no entanto, pode existir nessa proposição: ao caos não se chegaria pela ordem, pois não se trata de extremos opostos de uma escala, mas de entidades qualitativamente diferentes. Não bastaria eliminar o excesso de ordem, mas incluir nesta ordem a disposição (coragem) de, vez por outra, abandonar-se no caos.

Ontem no entanto perdi durante horas e horas a minha montagem humana. Se tiver coragem, eu me deixarei continuar perdida. Mas tenho medo do que é novo e tenho medo de viver o que não entendo - quero sempre ter a garantia de pelo menos estar pensando que entendo, não sei me entregar à desorientação. (PSGH, 12-13) 
Neste primeiro momento, o de desconstrução de valores, livrar-se das estruturas rígidas organizadas se torna tão necessário aos objetivos locais que acaba se atribuindo ao objetivo (o sujeito desprovido de construções desnecessárias que o deixam rígido demais) o valor de verdade. Mais tarde, G.H. questiona o movimento de desconstrução e a sua valorização excessiva. O que antes parecia verdade (o pólo neutro e a descoberta desse pólo), é relativizado em verdade parcial, parte de uma estrutura dupla, moral e neutra, que caracterizaria a condição humana. Uma nova moral não seria, mesmo sendo menos rígida, a desordem que ela pretenderia simular.

Finalmente, a covardia se associa com a vontade de entender, a necessidade de dar forma à experiência. A personagem tem medo de não entender, não poder prever, não poder formular. O medo de G.H. é o de simplesmente caminhar, simplesmente "ser", viver num plano anterior ao de poder formular, diferente do plano da palavra e de qualquer forma ou ordem.

Como é que se explica que meu maior medo seja exatamente em relação: a ser? e no entanto não há outro caminho. Como se explica que o meu maior medo seja justamente o de ir vivendo o que for sendo? como é que se explica que eu não tolere ver, só porque a vida não é o que eu pensava e sim outra - como se antes eu tivesse sabido o que era! (PSGH, 13)

Da suposição de sempre ser possível organizar, a G.H. anterior à experiência agarra-se à idéia de haver uma seqüência lógica no viver e que seu esforço de ordem atual e o possível sofrimento decorrente desse esforço, que calaria uma porção desorganizada de si mesma, seriam compensados por algo futuro. Em diversas passagens do livro, esta idéia de sacrifício atual pela recompensa futura é formalizada pela palavra "esperança". A esperança, para G.H., liga-se assim a seu medo. A esperança é o sentimento que sustenta a ordem atual e o medo é o que evita que a desordem se apodere da existência da personagem. O binômio esperança e medo é certamente sustentáculo da idéia bíblica da Paixão, ou seja, o sofrimento atual de um indivíduo pelo bem futuro de todos e de si. Pode ser lida, por exemplo em termos freudianos ${ }^{3}$, como a minimização das manifestações das pulsões agressivas e eróticas (tanatos e eros) em função da ordem civilizatória. O mal-estar seria aquietado pela esperança, enquanto eros e tanatos seriam paralisados pelo medo, que

\footnotetext{
${ }^{3}$ Freud, S. "O Mal estar na civilização" In: Os Pensadores: Freud (v.39). São Paulo: Abril Cultural, 1978.
} 
se aproxima bastante da idéia do sentimento de culpa feito do embate da ordem civilizatória e do superego com as pulsões primitivas animais.

No complemento do primeiro capítulo do livro, passa-se então a descrever a tensão entre ordem e caos em termos da possibilidade de formalizar em palavras a experiência não-verbal. A princípio, G.H. não acredita nessa possibilidade embora não veja outra alternativa a não ser organizar o que viveu, como se organizar fosse a condição humana, ou parte dela. Nessa organização do caos, perde-se a experiência, tem-se apenas uma suspeita do que ela foi. Assim, uma tensão do texto se constitui em torno de formalizar e dizer algo incompleto ou qualitativamente diferente da experiência, ou calar-se. No entanto, a angústia produzida pelo silêncio não seria suportável e, mais uma vez, dizer (formalizar, organizar) constitui-se como fatalmente humano: o único caminho possível é fracassado no fundamento. A diferença entre a experiência e a forma (palavras) conseguida inicialmente é tão grande que chega-se mesmo a duvidar da experiência vivida, que tem marcas na memória, embora não formalizadas. Ou, as marcas na memória estão formalizadas e já perderam o informe da experiência.

Quem sabe nada existiu! Quem sabe me aconteceu apenas uma lenta e grande dissolução? E que minha luta contra essa desintegração está sendo esta: a de tentar agora dar-lhe uma forma? Uma forma contorna o caos, uma forma dá construção à substância amorfa - a visão de uma carne infinita é a visão dos loucos, mas se eu cortar a carne em pedaços e distribuí-los pelos dias e pelas fomes - então ela não será mais perdição e loucura: será de novo a vida humanizada. (PSGH, 14)

A experiência existiu justamente pela não-organização, e só seria reatingida pela não-organização. A organização funcionaria, se tanto, como um simulacro da desorganização. É a idéia da obra de arte que tenta se aproximar do (simular um) indizível $^{4}$, a ordem que busca a desordem, o "escorpião encalacrado" (imagem utilizada por Davi Arrigucci Jr. para descrever a obra de Julio Cortázar ${ }^{5}$ ). Como o descrito tantas vezes na obra de Clarice, por exemplo em Água Viva ${ }^{6}$ e na própria Paixão:

\footnotetext{
${ }^{4} \mathrm{Ou}$, de maneira alternativa, pode ser a obra de arte que questiona as possibilidades de dizer, questiona a si mesma, questiona a linguagem e afirma-se como fracasso, sempre simulação, nunca a experiência.

${ }^{5}$ Arrigucci Jr., D. O Escorpião Encalacrado. São Paulo: Perspectiva, 1995.

6 AV - Lispector, C. Água Viva. Rio de Janeiro: Rocco, 1999.
} 
Ouve-me, ouve meu silêncio. O que falo nunca é o que falo e sim outra coisa. $(\mathrm{AV}, 28)$

O melhor ainda não foi escrito. O melhor está nas entrelinhas. (AV, 86)

O indizível só poderá ser me dado pelo fracasso da minha linguagem

(PSGH, 176)

Então escrever é o modo de quem tem a palavra como isca: a palavra pescando o que não é palavra. Quando essa não-palavra - a entrelinha morde a isca, alguma coisa se escreveu. Uma vez que se pescou a entrelinha, poder-se-ia com alívio jogar a palavra fora. Mas aí cessa a analogia: a não-palavra, ao morder a isca, incorporou-a. (AV, 20)

A distância entre a palavra e a coisa é mostrada também, por G.H., simbolicamente, em seu próprio nome. "G.H.", que é menos que um nome, está para as possibilidades da palavra assim como as palavras estão para as coisas. O nome que é ainda menos que um nome, G.H., simboliza a incompletude que é a palavra diante das coisas.

$\mathrm{O}$ resto era o modo como pouco a pouco eu havia me transformado na pessoa que tem o meu nome.

E acabei sendo o meu nome. É suficiente ver no couro de minhas valises as iniciais G.H., e eis-me. Também dos outros eu não exigia mais do que a primeira cobertura das iniciais do nome. (PSGH, 25)

Também no trecho citado "Uma forma contorna o caos, uma forma dá construção à substância amorfa - a visão de uma carne infinita é a visão dos loucos, mas se eu cortar a carne em pedaços e distribuí-los pelos dias e pelas fomes - então ela não será mais perdição e loucura: será de novo a vida humanizada.", a carne cortada em pedaços remete ao procedimento do fragmento na escrita de Clarice. Ainda que a soma simples dos fragmentos não reproduza o todo, pois nenhuma forma contornará o infinito, o fragmento é útil como recurso de escrita na medida, justamente, em que concretiza em si a idéia da parcialidade na representação (simulação) de um todo. $O$ fragmento, enquanto forma parcial, tem em si a idéia da precariedade da forma e, paradoxalmente, por assumir-se parcial, configura melhor a totalidade do que uma simulação que se afirme total. Esse é um 
dos tantos esforços de Clarice Lispector para não excluir da sua tentativa de texto a idéia de que é texto (artifício, construção) e não uma experiência mimetizada.

Ainda, se a narrativa caminha basicamente por questionamentos de um indivíduo diante do mundo, não se pode ignorar que as possibilidades de ordenação com as quais G.H. pauta sua vida são compartilhadas entre ela e um grupo social - a razoável objetividade da palavra e a fé (confiança) em que o que se diz será entendido. Não é casual, por exemplo, que a experiência de G.H. se dê num canto esquecido de seu apartamento. $\mathrm{O}$ quarto dos fundos (que pode simbolizar as profundezas da psicologia da personagem, esquecida, afastada do dia-a-dia) é sem dúvida também uma referência social. É no quarto da empregada que G.H. se desnuda de sua moralidade e encara-se amoral. O movimento é semelhante a vários outros no livro: a personagem vai de um pólo (patroa) a outro (empregada) de modo a definir o tipo de relação a ser questionada. O oposto evidencia a relativização da categoria inicial, mas é, em geral, na anulação de ambas as categorias, ou na anulação de sua oposição, que segue a narrativa. No caso agora discutido, a apresentação dos dois pólos da ordem social é substituído pelo (des)caminho neutro, da experiência do indivíduo, independente de qualquer ordenação de classe.

Havia anos que eu só tinha sido julgada pelos meus pares e pelo meu próprio ambiente, que eram, em suma, feitos por mim mesma e para mim mesma. (PSGH, 40)

Assim, embora não seja tão explícito na obra (como o é, por exemplo, em $A$ Hora da Estrela), a ordem social é enunciada em crítica. A inserção social e histórica da obra se dá, além de em passagens como a citação do quarto da empregada, em estruturas mais profundas da construção narrativa. Nos termos de Adorno, em "Lírica e Sociedade"7, o texto clariceano não se isolaria da sociedade em que a obra está inserida mesmo que não fizesse referência direta (e não é o caso) a elementos estruturadores dessa sociedade, na medida em que a verdadeira obra de $\operatorname{arte}^{8}$ ultrapassaria as ideologias para poder dizer o que estas escondem, embora permita leituras menos abrangentes em que a subjetividade do enunciador afasta-se de sua sociedade. Como na passagem a seguir, a personagem G.H. é retratada longe do convívio social, mas repleta de elementos representantes da estrutura

\footnotetext{
${ }^{7}$ Adorno, T. "Lírica e Sociedade", In: Os Pensadores v. 38. São Paulo: Abril Cultural, 1980.

${ }^{8}$ Vale dizer que "verdadeira" não combinaria com "obra de arte" segundo o discurso de G.H. em PSGH.
} 
social. G.H. é espelho de uma classe, em vários aspectos, e de uma ideologia que ultrapassa os limites de classe desde o momento de seu nascimento, o que pode ser chamado de uma moral.

Eu não me impunha um papel mas me organizara para ser compreendida por mim, não suportaria não me encontrar no catálogo. Minha pergunta, se havia, não era: "que sou", mas "entre quais sou". Meu ciclo era completo: o que eu vivia no presente já se condicionava para que eu pudesse posteriormente me entender. Um olho vigiava a minha vida. A esse olho ora provavelmente eu chamava de verdade, ora de moral, ora de lei humana, ora de Deus, ora de mim. Eu vivia mais dentro de um espelho. Dois minutos depois de nascer eu já havia perdido minhas origens. ${ }^{9}$ (PSGH, 28)

Tal submissão a valores e significados de um grupo fazem com que o conceito de ordem não seja puramente lógico-matemático, mas moral. O conceito de ordem, para a G.H. inserida em seu meio, não está exclusivamente relacionado, por exemplo, a entropia (medida matemática do grau de desordem de um sistema), mas a um julgamento de certo e errado. Ordem, para a G.H. moral, é correto e associa-se a bom (gosto), enquanto desordem é mau-gosto. Desordem é imoral aos olhos ideológicos de G.H. No entanto, à G.H. inserida na experiência com a barata, o que antes era desordem torna-se, de acordo com o descrito por ela, neutro e não submetido a julgamentos morais, amoral portanto.

Um passo antes do clímax, um passo antes da revolução, um passo antes do que se chama amor. Um passo antes de minha vida - que, por uma espécie de forte ímã ao contrário, eu não transformava em vida; e também por uma vontade de ordem. Há um mau-gosto na desordem de viver. E mesmo eu nem saberia, se tivesse desejado, transformar esse passo latente em passo real. (PSGH, 28)

Se, por um lado, a desconstrução ideológica parece induzir a idéia de um ser humano essencialmente amoral e sem ordem, por outro há, ao longo do texto, diversas

\footnotetext{
${ }^{9}$ Neste trecho há também a separação entre eu e mim, o que revela uma condição tanto subjetiva quanto objetiva do ser humano retratado em G.H., produto das escolhas de um eu e produto das escolhas de um mim.
} 
passagens que revelam o ser humano como um sujeito organizador.

E não apenas viva - como estava apenas viva aquela barata primariamente monstruosa - mas organizadamente viva como uma pessoa. (PSGH, 99)

É nessa parcela organizadora que se diferencia o humano do orgânico. Em $A$ Paixão Segundo G.H., diversas vezes aparece a palavra "humano", ou derivadas desta, para se referir justamente a essa característica humana que diferencia o homem do animal. $\mathrm{O}$ percurso do livro, no entanto, é cumprido em uma primeira parte (desconstrução moral) mais pela simulação do solo inumano, o mundo monstruoso da barata - o neutro que também está no homem mas que não é o que o faz especificamente humano - do que pela apresentação da parcela humana organizada e verbalizável.

Assim, em A Paixão Segundo G.H., apesar de o livro poder ser associado a um movimento de desconstrução, um convite ao amoral (o que, do ponto de vista da moralidade, incluiria o moral e o imoral, sem fazer julgamento), o ser humano é descrito como inevitavelmente organizador (moral). Desse modo, há, não um movimento de simples desconstrução, mas a crítica à construção reificada. A organização caduca e excessiva é que é alvo de crítica. Se organizar é inevitável, que se o faça mantendo a consciência de que se trata de uma construção que flutua no ar. Volta-se então à idéia de que a eliminação irrestrita da ordem não é uma escolha humana. A eliminação da ordem se daria, de acordo com o texto, apenas nos conhecidos momentos epifânicos clariceanos, na comunhão com o indizível. A proposta, se há uma, é o estabelecimento de uma ordem que inclua em si a possibilidade de estar errada, o que faz dessa organização algo mais dinâmico que rígidos conceitos de certo e errado, como no caso da eliminação da terceira perna (o excesso de humanidade que é desumanidade), o que não elimina o equilíbrio mas dá a ele alguma liberdade. Mais do que isso, vislumbrar a desordem numa experiência epifânica seria o inespecífico na existência, já que a organização é que é o especificamente humano. Organizar é inevitável. Resta então o modo de ser organizado.

O parágrafo a seguir ilustra bem muito do já dito até aqui:

Levantei-me enfim da mesa do café, essa mulher. Não ter naquele dia nenhuma empregada iria me dar o tipo de atividade que eu queria: o de 
arrumar. Sempre gostei de arrumar. Suponho que esta seja a minha única vocação verdadeira. Ordenando as coisas, eu crio e entendo ao mesmo tempo. Mas tendo aos poucos, por meio de dinheiro razoavelmente bem investido, enriquecido o suficiente, isso impediu-me de usar essa minha vocação: não pertencesse eu por dinheiro e por cultura à classe a que pertenço, e teria normalmente tido o emprego de arrumadeira numa grande casa de ricos, onde há muito o que arrumar. Arrumar é achar a melhor forma. ${ }^{10}$ (PSGH, 33)

"Melhor", nesse contexto, parece menos um julgamento moral abrangente que a satisfação íntima de um motivo. "Melhor" é um jeito que sirva à necessidade de matar uma fome, seja ele qual for, sem ter que se ajustar a um modelo generalizável e ideal.

Em A Paixão Segundo G.H. é, assim, central a oposição entre ordem e desordem. Dependendo dos olhos de quem lê, pode ser vista como a contraposição entre consciente e inconsciente (psicanálise), ou entre apolíneo e dionisíaco (Nietzsche), por exemplo, além de várias outras possibilidades de recortar e organizar o livro. Como qualquer sistema de idéias, as idéias de Freud e Nietzsche podem se adaptar bem ou mal ao objeto que precisa ser dito. Para Clarice, em A Paixão Segundo G.H., parece razoável que qualquer destes ou quaisquer outros sistemas de idéias jamais se adaptem completamente ao objeto. Ambos são úteis e parciais (pois, enquanto sistema, são discurso, ordem que se opõe ao caos). Algo que diferenciaria no fundamento um sistema de outro seria a inclusão da possibilidade da falha. Isso dá dinâmica ao homem que adere a um ou a outro sistema.

Clarice refere-se sempre, no livro, a "moral", algo que faz desses sistemas de idéias entes necessariamente ligados a valores. Um sistema moral excessivamente rígido, como o em que estava inserida G.H. antes de sua experiência epifânica, não inclui nele mesmo a possibilidade de ser falho nem a maleabilidade para se moldar, se necessário for, para melhor simular um mundo. Presa nesta moral, G.H. é medrosa, o que equivale a dizer que ela receia o novo e tende a permanecer com os mesmos valores, a não ser que uma experiência radical como foi a que teve a empurre para outro lugar. A dificuldade de

${ }^{10}$ (grifos meus) 
assumir a nova moral está justamente na falta de coragem, ou seja, o medo ligado à moral anterior. A coragem é o elemento que faria a diferença significativa entre a moral anterior e a nova moral e permitiria que o indivíduo se deixasse, por vezes, no incompreensível, aceitando a falha (a possibilidade de o sistema moral não compreender a experiência como um todo). É também da coragem e da ação (que se opõem à inação provocada pelo medo) que surge a possibilidade de que a nova moral seja dinâmica, moldável. Neste ponto, ação se confunde com escolha e liberdade, e se opõe ao medo, que estaria associado a uma estrutura equivalente à má-fé sartriana, e que impediria o homem de se conhecer e de se fazer sujeito no mundo.

\section{Sujeira - mais alguns espasmos}

Como já foi dito, limpeza, assim como ordem, associa-se a valores ideais adquiridos durante a formação do indivíduo para facilitar sua vida em sociedade e a existência da sociedade em relação a ele. Faz parte de um conjunto básico de regras para distinguir certo e errado. Difere da ordem, no entanto, por ser mais específico. É possível entender limpeza como um tipo de ordem. Dentro das possibilidades de significação, limpeza é um conceito próximo de higiene e, assim, muitas vezes se relaciona diretamente com o corpo humano e sensibiliza os diferentes órgãos dos sentidos. Ordem afeta, de modo geral, inicialmente a visão. Limpeza ou sujeira podem ser reconhecidas pelo olfato e pelo paladar, por exemplo, portas mais escancaradas para as vísceras humanas, e, pelo menos nesse aspecto, relacionam-se de maneira mais imediata com a faceta animal (corpo) do homem. Por essa especificidade em relação à ordem, a desconstrução do conceito do que seja limpo abre as portas para a exploração do incontrolável humano em suas reações espasmódicas, imediatas, caóticas e incontinentes.

No caso da limpeza (e de ordem também, é possível em alguns casos), a reação adversa provoca a suspensão dos controles usuais e das cadeias causais e temporais. Sob efeito do nojo extremo, suspende-se o mundo - o indivíduo passa a ser apenas seu nojo e o desespero de livrar-se dele. Ou: suspendem-se as distâncias entre o sujeito e o mundo, sendo tudo o nojo. Torna-se mais evidente, assim, a dificuldade de separar o moral do nãomoral nesta dimensão em que o conceito construído historicamente e socialmente provoca 
uma reação e leva o indivíduo ao incontrolável. O indivíduo tem restringidas suas possibilidades de escolha.

O princípio que rege a moral de G.H. em relação à limpeza é descrito inicialmente como o de uma vestal. Vesta, a deusa romana equivalente à grega Héstia, era a responsável pela conservação do fogo do qual dependeria a salvação da cidade. As vestais eram sacerdotisas, virgens como Vesta, que tornariam possível a missão da deusa. Parte do trabalho das vestais era então a limpeza do templo. Em Roma, instituiu-se a Vestália, festa grandiosa realizada sempre na mesma época do ano, época de maus augúrios, para a purificação da cidade. A purificação só era considerada completa quando todo o lixo da cidade era jogado num rio. O fato de a limpeza ser feita exatamente após uma grande festa não é casual. É a manutenção da limpeza e da ordem da cidade depois da sujeira e da desordem autorizadas. "Vestal", em A paixão segundo G.H., é um símbolo forte de limpeza, como a deusa Vesta e suas sacerdotisas vestais, associado à conservação dos princípios morais, da família e da cidade. Evidentemente, limpeza e ordem estão associadas nas figuras míticas de Vesta e das vestais. A experiência de G.H. com a barata é diretamente associada à sujeira e, em paralelo, à suspensão da vigência da moral, enquanto a vestal representa a moral que se esforça em guardar a ordem e a limpeza tradicionais. Curioso também é que a sujeira é autorizada em determinado momento por uma instância ligada à moral - as vestais fazem parte do sistema normativo -, o que retrata a desconfiança implícita no discurso de G.H. em relação à suspensão fácil e intencional das leis morais.

Sou a vestal de um segredo que não sei mais qual foi. E sirvo ao perigo esquecido. Soube o que não pude entender, minha boca ficou selada, e só me restaram os fragmentos incompreensíveis de um ritual. (PSGH, 16)

Desse modo, a suspensão das leis morais tem que passar por (e fica sempre associada a) leis rituais. Estes encadeamentos lógico-mágicos são recorrentes na obra de Clarice Lispector e respondem pela aproximação do indivíduo à região do impasse em que ele estaria igualmente sujeito aos desígnios do controlável e do não-controlável.

A limpeza é, assim, um ideal de ordem sobre as necessidades físicas, às vezes pulsionais. É necessário, por exemplo, comer "delicadamente", sem se sujar. 
Esse modo de não ser era tão mais agradável, tão mais limpo: pois, sem estar agora sendo irônica, sou uma mulher de espírito. E de corpo espirituoso. À mesa do café eu me enquadrava com meu robe branco, meu rosto limpo e bem esculpido, e um corpo simples. De mim irradiava-se a espécie de bondade que vem da indulgência pelos próprios prazeres e pelos prazeres dos outros. Eu comia delicadamente o meu, e delicadamente enxugava a boca com o guardanapo. (PSGH, 32)

A limpeza associa-se também à beleza como, por exemplo, um de seus critérios. Ambas, limpeza e beleza, fazem parte do sistema moral em que G.H. se insere. Basta a ela que reproduza os valores desse sistema para que seja reconhecida pelos demais membros do grupo como alguém bonito e limpo. Ao mesmo tempo, ganhará outras qualidades valorizadas no grupo, como generosidade e graça. Em acordo com tais critérios, uma pessoa, como G.H., cria a imagem de inofensiva (não oferece riscos ao grupo). A passagem a seguir ilustra bastante bem toda essa associação de idéias:

Enquanto eu mesma era, mais do que limpa e correta, era uma réplica bonita. Pois tudo isso é o que provavelmente me torna generosa e bonita. Basta o olhar de um homem experimentado para que ele avalie que eis uma mulher de generosidade e graça, e que não dá trabalho, e que não rói um homem: mulher que sorri e ri. Respeito o prazer alheio, e delicadamente eu como o meu prazer, o tédio me alimenta e delicadamente me come, o doce tédio de uma lua-de-mel. (PSGH, 31)

Essa idéia de citação dos comportamentos do grupo em vez de ação com maior autoria repete-se ao longo do livro. Os valores do grupo ditam comportamentos, o que significa que os motivos dos homens tornam-se exteriores a eles mesmos. A alma (anima, aquilo que dá a vida, princípio motor) dos seres (não é razoável utilizar a palavra "indivíduo" nesse contexto) é exterior a eles. O percurso de G.H. aponta, como será discutido mais à frente, para uma relação menos submissa entre o homem e o mundo, de modo que seus próprios motivos sejam considerados em sua existência. Assim, o homem se moveria por uma associação entre sua alma no grupo social e sua alma, agora sim, individual. 
$\mathrm{Na}$ passagem da página 32, citada há pouco, parece haver uma ironia fina na contraposição dessa alma motora e a palavra "espírito", que seria o modo de classificar educadamente alguém que seguisse à risca, sem exageros, os preceitos da moral do grupo. Na mesma frase, a observação "sem estar agora sendo irônica" intensifica o tom irônico da passagem. Ironia, no sentido de "discurso distanciado". Diz-se uma coisa, para dizer o contrário. De determinado ponto de vista moral, "espírito" é, em algumas acepções, o contrário do que é "alma".

A primeira imagem importante que associa, no livro, a experiência de G.H. com a barata como algo sujo é o quarto da empregada. A expectativa de G.H. é a de encontrar um quarto sujo e, que por um princípio moral - por ser sujeira -, deve ser evitado ou escondido.

o quarto da empregada devia estar imundo, na sua dupla função de dormida e depósito de trapos, malas velhas, jornais antigos, papéis de embrulho e barbantes inúteis. Eu o deixaria limpo e pronto para a nova empregada. (PSGH, 34)

No entanto, o que ela encontra é um quarto limpo e arrumado pela empregada Janair, que no silêncio fez com que mesmo as porções mais escondidas da casa estivessem arrumadas. É como se houvesse diferentes camadas de existência, mais ou menos acessíveis, sobrepostas, e que todas as camadas que G.H. podia alcançar, da sala ao quarto de empregada, estivessem submetidas a sua rígida moral. E que a vida nua, amoral, estivesse ainda mais escondida, talvez inacessível.

A imagem da empregada surge forte como elemento da lógica social, a mesma de G.H.. Janair colabora com G.H., embora em camadas mais escondidas, para manter a limpeza e a ordem da casa. Neste ponto, elas não se diferenciariam essencialmente, pois partilhariam os mesmos valores (sem que lugares sociais possam ser confundidos. A própria G.H. se refere a isso quando supõe que, não tivesse dinheiro e cultura, seria arrumadeira). Ambas trabalham em camadas diferentes da mesma ordem (moral). As camadas menos valorizadas (Janair, o quarto da empregada) são, num primeiro momento, tidas como desordenadas e sujas: desvalorizadas e desaconselhadas (proibidas) como qualquer outra porção do desconhecido. 
não pertencesse eu por dinheiro e por cultura à classe a que pertenço, e teria normalmente tido o emprego de arrumadeira numa grande casa de ricos, onde há muito o que arrumar. (PSGH, 33)

Não é possível negar, no entanto, que G.H. e Janair, justamente pelo dinheiro e pela cultura, assumem diferentes papéis sociais. As características que as fazem diferentes são um parâmetro exterior a elas - o dinheiro - e um adquirido ao longo da vida - cultura ${ }^{11}$, ferramentas específicas para pensar, que cada uma adquire de um modo devido à distinção entre as classes onde elas se encaixam desde que nasceram - dentro de um acordo e uma lógica sociais, comuns às duas, que pouco dependem de suas escolhas. Do ponto de vista moral, a empregada é quem está mais perto da sujeira o tempo todo, enquanto à patroa resta apenas a arrumação mais fina. Esse movimento de colocar G.H. patroa no papel de arrumadeira faz com que ela se aproxime da sujeira, conhecendo o avesso do seu mundo moral limpo. No entanto, o movimento que vai da limpeza (moral) à sujeira (imoral) só se completa com a anulação dos opostos, como tantos outros exemplos no livro, apontando para o não-moral, que é o espaço da experiência com a barata. Assim, além do local - o quarto da empregada- , a empregada, papel social, é também imagem que anuncia a experiência com o imundo (classificação feita pelo ponto de vista de uma moralidade). Ainda, os papéis sociais de G.H. e de Janair se diferenciam por um papel ser essencialmente braçal e o outro intelectual, embora submetidos a diversos pontos comuns de uma mesma ideologia.

Curioso é que, ao encontrar o quarto limpo, um desagrado físico é sentido por G.H., o que normalmente seria sentido pelo contato com a sujeira e não com a limpeza. Isso faz com que se relativize a regra moral, como índice do neutro amoral que o discurso da narradora pretende dizer.

Mas ao abrir a porta meus olhos se franziram em reverberação e desagrado físico.

É que em vez da penumbra confusa que esperava, eu esbarrava na visão de um quarto que era um quadrilátero de branca luz; meus olhos se

\footnotetext{
${ }^{11}$ A cultura se confunde, muitas vezes, com a ideologia, e com ela interage para fornecer ao indivíduo seus modos de recortar o mundo. G.H. e Janair compartilham vários desses modos de pensar, mas se diferenciam por terem histórias de vida separadas pelas determinações de classe. Em A Hora da estrela, escrito treze anos depois de PSGH, essas determinações que as diferenciam passam da periferia ao centro das discussões da narrativa, na oposição entre o narrador Rodrigo S.M. e a protagonista Macabéa.
} 
protegiam franzindo-se.

Há cerca de seis meses - o tempo que aquela empregada ficara comigo eu não entrava ali, e meu espanto vinha deparar com um quarto inteiramente limpo." (PSGH, 37)

A inversão da sensação é dada pela quebra de expectativas. Frente à limpeza onde haveria sujeira, é como se G.H. pisasse em falso em seu mundo conhecido e vislumbrasse o tamanho do abismo no qual iria cair. G.H. encara, pela primeira vez em seu percurso, seus processos subterrâneos e desconhecidos, embora ainda morais (personificados na empregada). É pela representação das diferentes camadas da ordem que Clarice pode organizar um livro que fala de desordem. É pelo reconhecimento de uma ordem antes desconhecida que se simula a desordem. O fenômeno organizado desconhecido é absorvido como desordem para quem (ainda) não possui as categorias necessárias para organizá-lo.

O desagrado físico em relação à visível limpeza do quarto da empregada retrata também uma moral que guarda os lugares específicos mesmo para a desordem e a sujeira. Aprofundando-se nas camadas de sua existência, G.H. continua, durante várias camadas, submetida a princípios morais. Há ordem até na simulada desordem. A moral, nesse sentido, é mais profunda que as aparências, ela rege comportamentos que podem ser considerados naturais. Embaixo da construção ordenada, encontra-se outra construção ordenada. E embaixo desta... até a barata. Ou na imagem da barata:

E eis que eu descobria que, apesar de compacta, ela é formada de cascas e cascas pardas, finas como as de uma cebola, como se cada uma pudesse ser levantada pela unha e no entanto sempre aparecer mais uma casca, e mais uma. Talvez as cascas fossem as asas, mas então ela devia ser feita de camadas e camadas finas de asas comprimidas até formar aquele corpo compacto. (PSGH, 56)

Dos percursos de ordenação e limpeza, nasce uma nova idéia no livro, a de que, em camadas mais profundas, concretizadas no quarto da empregada, há valores e significados em nós que seriam apenas vestígio da história da humanidade, não necessariamente da nossa história pessoal. Esses vestígios seriam fragmentos de uma organização que teve 
alguma utilidade imediata em algum momento da história da espécie e que restaram como valores e significados, ainda existentes, mas que perderam sua ligação imediata com o mundo existente. É um conjunto de idéias que acompanha toda a humanidade, compartilhadas pela cultura ou pelos genes, resquícios fósseis fragmentados de nossa história e de valores necessários em outras épocas. A nós, hoje, podem ser úteis, ou, em geral, apenas complicar o entendimento de nós mesmos e nossas motivações. No trecho a seguir, ajudam no retrato desse arcabouço fragmentado, a agulha que toca a música que já acabou, as referências ao outro que existe dentro de si mesmo, à rainha africana, do país estrangeiro.

E nada ali fora feito por mim. No resto da casa o sol se filtrava de fora para dentro, raio ameno por raio ameno, resultado do jogo duplo de cortinas pesadas e leves. Mas ali o sol não parecia vir de fora para dentro [...] Eu me preparara para limpar coisas sujas mas lidar com aquela ausência me desnorteava.

Percebi então que estava irritada. O quarto me incomodava fisicamente como se no ar ainda tivesse até agora permanecido o som do riscar do carvão seco na cal seca. O som inaudível do quarto era como o de uma agulha rodando no disco quando a faixa de música já acabou. Um chiado neutro de coisa, era o que fazia a matéria de seu silêncio. Carvão e unha se juntando, carvão e unha, tranqüila e compacta raiva daquela mulher que era a representante de um silêncio como se representasse um país estrangeiro, a rainha africana. E que ali dentro de minha casa se alojara, a estrangeira, a inimiga indiferente. (PSGH, 42-43)

Ainda, nota-se nessa idéia das camadas morais parte da concepção de que a linguagem (a moral) está diretamente ligada a finalidades (1) imediatas ou (2) fósseis, resquícios de finalidades imediatas de antepassados. Dessa ordenação muitas vezes desnecessária é que G.H. tenta então se livrar enquanto cumpre um percurso. Queria se livrar - enquanto descobria suas camadas arqueológicas, de sua herança filogenética, resultado da experiência de seus antepassados - pelo menos do que não é sua própria 
experiência, para atingir algo que, depois do despojamento, seria ainda ela mesma. G.H. corre atrás de uma identidade anterior a todas as camadas dispensáveis, de modo que ainda seja ela mesma. Dentro do guarda-roupa, mais uma camada retirada, ela mesma, finalmente, a sujeira, era a barata.

Como ali, no quarto nu e esturricado, a gota virulenta: numa limpa proveta de ensaio uma gota de matéria.

Olhei o quarto com desconfiança. Havia a barata, então." (PSGH, 48)

E quando se livra das porções mais anteriores da moral (que se concretiza em ordem, beleza e limpeza), G.H. descobre em si um porquê para tanta proibição acumulada durante uma história, o proibido que se simboliza na vontade de matar.

Eu me embriagava pela primeira vez de um ódio tão límpido como de uma fonte, eu me embriagava com o desejo, justificado ou não, de matar. Toda uma vida de atenção - há quinze séculos eu não lutava, há quinze séculos eu não matava, há quinze séculos eu não morria - toda uma vida de atenção acuada reunia-se agora em mim e batia como um sino mudo cujas vibrações eu não precisava ouvir, eu as reconhecia. Como se pela primeira vez enfim eu estivesse ao nível da Natureza." (PSGH, 53)

Para Freud $^{12}$, três são as ações proibidas mais comuns às diversas culturas: assassinato, canibalismo e incesto (Freud admite que, em determinadas culturas e determinadas situações, as proibições podem ser suspensas). Certamente, tais atos teriam seus fundamentos nos motivos animais mais básicos: agressividade, fome e reprodução, que são controlados pelas culturas para facilitar a vida em sociedade. Quando G.H. encontra em si a vontade de matar é porque já se livrou de diversas camadas culturais que a proibiam mesmo de saber que possuía tal vontade. Mais à frente, no livro, depois de se identificar com a barata, fazendo desta um duplo, não resiste ao desejo de colocá-la na boca: comê-la, e, assim, assumir também o canibalismo como um desejo seu. Antes, porém, para sentir a barata como um semelhante, precisou passar pelo nojo, associado à sujeira e à barata desde tempos imemoriais.

\footnotetext{
${ }^{12}$ Freud, S. "O porvir de uma ilusão" In: Os Pensadores: Freud (v.39). São Paulo: Abril Cultural, 1978.
} 
Assim, enquanto se livrava de seus valores culturais, G.H. livrava-se da noção de sujo e limpo. Mas essa noção é tão visceral que, mesmo quando já está disposta a colocar a barata na boca, ainda sente nojo. Pouco depois é que percebe que ainda havia moralidade a ser descartada, que o ato de sobrepujar o próprio nojo era desprendimento mas também heroísmo (moralidade).

O livro segue, então, para a tentativa de reconstrução dos valores, de modo menos rígido. O nojo é recolocado no rol de qualidades necessárias ao ser humano. No entanto, a proposta é que o nojo seja reintegrado como a consciência de um limite, não a proibição irracional imposta externamente. Depois de desconstruir os valores, constrói-se uma moral em que todos os valores são questionáveis e de cuja construção tem-se mais consciência. $O$ nojo é um limite sobre o qual sabe-se que, ultrapassado, não se estará sendo especificamente humano. Depois do nojo, não há controle. Não é mais a idéia de certo ou errado, mas de assumir ou não um risco.

Mas o nojo me é necessário assim como a poluição das águas é necessária para procriar-se o que está nas águas. O nojo me guia e me fecunda. (PSGH, 113)

Limpeza é, em $A$ paixão segundo G.H., como ordem, um conceito associado a moral. G.H. vive sua experiência epifânica no dia em que resolve arrumar (limpar) o apartamento, depois que a empregada foi definitivamente embora. A personagem vai da sala ao quarto da empregada. Lá abre o armário e encontra a barata. Esse percurso espelha uma complexidade moral que vai sendo explorada pela personagem. As primeiras camadas atravessadas ainda são morais, uma moralidade antes desconhecida de G.H., até que, ao nível do Neutro, encontra a si mesma espelhada na barata. Enquanto busca, não sabe o quê, G.H. cria a expectativa de encontrar o sujo, por exemplo no quarto da empregada, mas o quarto está surpreendentemente limpo, uma moralidade (cultura) desconhecida, mas ainda moralidade. Conforme se aproxima da experiência neutra, a barata, a sujeira e o nojo são descritos com mais freqüência. Mas na identificação com a barata, somem os opostos sujeira/limpeza no silêncio da experiência não-verbal. 
Após arrancar/perder todas as camadas de cultura e encontrar-se na barata, G.H. procura, como necessidade, reconstruir. Em vez, no entanto, de reconstruir uma moral rígida com preceitos definitivos de certo e errado, procura um sistema provisório. O errado, o sujo por exemplo, passa a ser um limite. Atravessá-lo é arriscado mas não proibido. A consciência do risco substitui, em G.H., pelo menos como proposta, as proibições irracionais e ideológicas.

Tudo funciona como um processo de esvaziamento da moralidade, restando, num processo idealmente bem sucedido, apenas a moral provisória, de pequena abrangência, e a irracionalidade orgânica. Vale notar que processos ideais não correspondem de modo algum a sistemas morais provisórios. G.H. percebe isso ao longo da narrativa, desconfiando de toda a desconstrução moral e denunciando a seqüência como construção de uma desconstrução.

\section{Beleza - a proposta de eliminação da mediação estética}

Antes de abordar a especificidade de beleza em relação a A Paixão segundo G.H., vale dizer mais uma vez que, assim como ordem e limpeza, limpeza funciona como uma das facetas da moralidade. O belo, segundo o que se diz no livro, é uma idéia sobre a qual os indivíduos numa sociedade estão de acordo. Relaciona-se ao discurso e à razão. Wittgenstein, em suas Investigações Filosóficas ${ }^{13}$, é contundente nesse aspecto. Se, em sua obra anterior, o Tractatus Lógico Filosófico ${ }^{14}$, ele encarna o ponto de culminância da idéia de que a linguagem e a lógica são projeções de algo interior aos indivíduos, o que ele chamou de objetos simples (a comunicação entre os indivíduos seria possível justamente por todo o gênero humano possuir em sua natureza esses objetos), no segundo livro Wittgenstein nega radicalmente o que disse antes e afirma que a comunicação e a razão existiriam somente no contato entre seres humanos, nascidas de necessidades e ações concretizáveis. Assim, não haveria dentro do indivíduo nada que motivasse sua linguagem a não ser sua disposição para escolher e agir. Para concretizar essas vontades, criam-se as linguagens como modo de interagir com o outro e com o mundo.

\footnotetext{
${ }^{13}$ Wittgenstein, L. Investigações Filosóficas. São Paulo: Abril Cultural, 1984.

${ }^{14}$ Wittgenstein, L. Tractatus Logico-Philosophicus. São Paulo: Nacional, 1968.
} 
Clarice parece se aproximar bastante do segundo momento de reflexão de Wittgenstein. Em A Paixão segundo G.H., a linguagem se separa radicalmente de uma instância não-verbal, que é normalmente o de que se fala quando se fala da obra clariceana. A linguagem não daria conta da expressão daquilo que os personagens experimentam em seus momentos epifânicos. A experiência do não-verbal é como uma visão mística: a sensação da totalidade é dada pela experiência mais simples, apenas existir, sem finalidade. O ser, não o nada. Como para Wittgenstein, a linguagem está sempre ligada a uma finalidade, à experiência engajada. A linguagem é construção e se associa à realização de um trabalho. A existência simples, total e sem finalidade, ficaria assim incomunicável. O belo literário, apoiado na palavra, não poderia, dentro dessa concepção de linguagem, ser outra coisa que não uma expressão humana submetida a finalidades específicas sem se referir a nenhum modelo absoluto.

Nas palavras de G.H., duas diferentes idéias são expressas por beleza. A primeira é uma beleza moral, ligada à comunicação e, necessariamente, à finalidade. Os critérios são exteriores, os valores e significados são dados. O belo é a citação, em algum modo, de tais critérios sociais.

A espirituosa elegância de minha casa vem de que tudo aqui está entre aspas. Por honestidade com uma verdadeira autoria, eu cito o mundo, eu o citava, já que ele não era nem eu nem meu. A beleza, como a todo o mundo, uma certa beleza era o meu objetivo? eu vivia em beleza? (PSGH, 31)

Dessa beleza, G.H. se desliga pouco a pouco em sua experiência com a barata.

A segunda beleza é a beleza do neutro, da totalidade, do mergulho em si mesmo que se faz pelo abandono da linguagem e da moral. Chama-se "beleza" por necessidade, posterior à experiência, de dar um nome à coisa. Enquanto a primeira beleza, ligada diretamente ao mundo da palavra, se submete a uma classificação e pode receber o carimbo "belo" sem que isso seja motivo de questionamento, a beleza do neutro recebe este nome (beleza) não pelo que é em si. O todo (enquanto todo e antes de ser recortado) não pode ser carimbado por um observador (externo) pois não haveria nada exterior a este todo. Dá-se o nome de beleza, então, a algo que é aproximado pelo discurso, passando-se pelo caminho da primeira beleza, a moral (por analogia a algo classificável e da ordem do 
discurso). Assim, indo-se do belo idealizado ao destituído de beleza, eventualmente acrescentando características do feio idealizado (oposto ao belo), cobre-se toda uma dimensão moral de beleza, do mais ao menos belo. O que não pode ser compreendido, resumido a esta dimensão (todo o percurso), é a beleza neutra. Do mesmo modo, ordem e limpeza foram utilizados para descrever o neutro.

Não a claridade que nasce de um desejo de beleza e moralismo, como antes mesmo sem saber eu me propunha; mas a claridade natural do que existe, e é essa claridade natural o que me aterroriza. (PSGH, 18)

Seguindo esse caminho, tem-se que, para Clarice Lispector (idéia expressa nas palavras da narradora G.H.), a sua busca inicial é por dizer o neutro e não pela beleza petrificada da moral rígida.

Sentia que o meu de dentro, apesar de matéria fofa e branca, tinha no entanto força de rebentar meu rosto de prata e beleza, adeus beleza do mundo. Beleza que me é agora remota e que não quero mais - estou sem poder mais querer a beleza - talvez nunca tivesse querido mesmo, mas era tão bom! ou me lembro como o jogo da beleza era bom, a beleza era uma transmutação contínua.

Mas com alívio infernal eu me despeço dela. (PSGH, 83)

Sua busca é por uma estética que seja a não-estética, o paradoxo da comunicação pela expressão não formalizada. Mais uma vez, o escorpião morde o próprio rabo, como na já citada imagem de Davi Arrigucci Jr. para a obra de Julio Cortázar: O Escorpião encalacrado ${ }^{15}$. Até um limite em que a escrita seria menos que um código, apenas um grafismo.

Até criar a verdade do que me aconteceu. Ah, será mais um grafismo que uma escrita, pois tento mais uma reprodução que uma expressão. (PSGH, 21)

${ }^{15}$ ArrigucCI JR., D. op.cit. 
Neste ponto, as figuras traçadas na parede do quarto de Janair ganham, enquanto grafismo, a força de escrita. Mais ainda, em épocas imemoriais, atribuía-se poder mágico às figuras traçadas nas paredes das cavernas. O desenho não só representava o objeto como presentificava e era, de algum modo, o próprio objeto. Assim, uma cena de caça concretizada numa parede era já a caça realizada. A aproximação entre o significante e o objeto (ou cena) motivador do significado era total. Num extremo é exatamente essa a proposta mágica de Clarice nas palavras de G.H. O movimento de aproximação entre palavra e grafismo é semelhante à aproximação entre grafismo e ente físico. A mágica impossível do ponto de vista da lógica se daria pela aproximação completa entre palavra e fenômeno.

No nível de apenas grafismo, a expressão verbal escrita aproxima-se demais de um dos aspectos da experiência (visual), embora entre em contradição com a expressão literária, fundada na palavra, no símbolo. Nesse aspecto, a proposta de Clarice (G.H.) não é a da expressão mas a da reprodução da experiência, o que exigiria a total desintegração dos sujeitos e da palavra, a identificação do sujeito com o objeto, assim como o ato de G.H. colocar a barata na boca é um ato desesperado de identificação que elimina o sujeito e seu ponto de vista.

Às vezes - às vezes nós mesmos manifestamos o inexpressivo - em arte se faz isso, em amor de corpo também - manifestar o inexpressivo é criar. (PSGH, 142)

Será preciso "purificar-me" muito mais para inclusive não querer o acréscimo dos acontecimentos. Antigamente purificar-me significaria uma crueldade contra o que eu chamava de beleza, e contra o que eu chamava de "eu", sem saber que "eu" era um acréscimo de mim. (PSGH, 173)

Por outro lado, desde que se assume a impossibilidade de a literatura sem palavra, a proposta, se ainda houver uma, passa a ser a de produzir uma literatura que esteja o mais próximo possível de uma experiência, em vez de ser reprodução da experiência - palavras que funcionem para o leitor como algo presente e não a simples reprodução do passado. Em Água Viva, diversos questionamentos sobre o assunto: 
[...] isto tudo não acontece em fatos reais, mas sim no domínio de uma arte? Sim $(A V, 19)$

Eu não. Quero uma verdade inventada. (AV, 20)

Para Cortázar, a literatura (modo específico da obra de arte) deve fugir à linguagem petrificada, ao significado pré-definido, se tiver a intenção de se aproximar da experiência viva. A experiência, que é sempre nova, sucessão de momentos presentes, é simulada pela linguagem que é nova, que surpreende. Embora a comunicação dependa de um acordo anterior, entre os interlocutores, sobre a linguagem, é necessário que esse acordo seja mínimo, que (na imagem de G.H.) se elimine a terceira perna, desnecessária.

Nada mais material e dialético e tangível que a pura imagem que não se ata à véspera. $\left(\right.$ Cortázar $\left.{ }^{16}\right)$

E quando estranho a palavra aí é que ela alcança seu sentido. (AV, 76)

Assim, o conceito (necessariamente moral) de beleza proposto por Clarice alinha-se com as demais ramificações de A Paixão Segundo G.H. na proposta de uma moral menos rígida. Tal moral menos rígida, que se aproxima constantemente do amoral e que inclui a possibilidade de sua própria falha, exige um modo de expressão também menos rígido, não petrificado, que não se identifique com a linguagem da véspera. A simulação do amoral se dá pela desorganização da linguagem, pela supressão de parte dos moldes préestabelecidos, pelo uso do fragmento, do paradoxo, pela surpresa, pelo susto. Se toda experiência é nova, a novidade na expressão é a forma adequada para que o formal seja recebido pelo leitor como algo próximo do informe. Não identificando o que leu com suas leituras anteriores, seus moldes morais de significados, é que o leitor aproxima a palavra da experiência não-verbal. Do mesmo modo, a utilização da linguagem tem de diminuir a vigência dos valores de bonito e feio para aproximar a palavra (moral) do amoral.

Pois nunca até hoje temi tão pouco a falta de bom-gosto: escrevi "vagalhões de mudez", o que antes eu não diria porque sempre respeitei a beleza e a sua moderação intrínseca.

\footnotetext{
${ }^{16}$ Cortázar, J. Prosa do Observatório. São Paulo: Perspectiva, 1974.
} 
Disse "vagalhões de mudez", meu coração se inclina humilde, e eu aceito. Terei enfim perdido todo um sistema de bom-gosto? Mas será este meu ganho único? Quanto eu devia ter vivido presa para sentir-me agora mais livre somente por não recear mais a falta de estética... (PSGH, 20)

O conceito (moral) de beleza perde, assim, validade eterna e torna-se apenas conceito. A consciência de sua fluidez é parte da proposição de uma moral menos rígida.

Mas o que hoje é feio será daqui a séculos visto como beleza, porque terá completado um de seus movimentos. (PSGH, 159)

Romper-se-iam então, junto com as noções de bom gosto, as noções de gênero literário, de romance, o que de algum modo justifica a estranheza de alguns ao encarar $A$ Paixão Segundo G.H. como um romance, pela quase ausência de enredo. Em Água Viva, essa noção de gênero é ainda mais radicalmente rompida. Se nos livros anteriores a este, acompanhavam o título uma nota, tal como "contos", "romance", em Água Viva, a nota é o mais amplo "ficção". Deste livro é a conhecida frase sobre gêneros literários:

Gênero não me pega mais $(\mathrm{AV}, 13)$

Além de ordem e limpeza, também beleza se relaciona diretamente a moral. O percurso de G.H., na anulação de sua subjetividade até a identificação completa, ou quase, com o objeto - a barata -, se dá acompanhado da relativização das certezas a respeito das idéias de bonito e feio, ao mesmo tempo que todas as outras categorias morais são igualmente dissolvidas.

Mas agora tenho uma moral que prescinde de beleza." (PSGH, 151)

A especificidade da discussão a respeito do belo em relação aos seus pares - limpo e organizado - é que introduz, nessa discussão, a idéia clariceana sobre a obra de arte e, em 
particular, a literatura. Na medida em que a proposta de G.H. é o estabelecimento de uma moral que inclua em si a consciência do seu avesso (amoral), o retrato dessa moral exige a relativização de qualquer categoria lógica, o que nas palavras de G.H. se confunde com as categorias morais. Uma tensão surge dessa idéia na medida em que a literatura se baseia em códigos e organização, situação oposta ao mundo amoral repleto de paradoxos ${ }^{17}$. Tal tensão é um dos potenciais que movem a literatura de Clarice Lispector. Enquanto literatura, é ordem, é palavra, é moral, é finalidade, mesmo que tente retratar, ou finja retratar a desordem (o mundo não-verbal, sem finalidade, não avaliado nem significado). A beleza buscada por Clarice Lispector, o fundamento estético de sua obra, apesar de possuir uma faceta moral (no sentido usado por G.H.), pois é palavra, aponta para a beleza neutra de simplesmente ser. Tal beleza, uma impossibilidade lógica, existe pelo menos enquanto categoria literária em sua obra. A palavra que quer servir à não-palavra poderia até não existir como efeito no leitor mas surge, ao menos, como proposta de escrita.

Se se observa o discurso de G.H. como uma proposta de desconstrução que é seguida de uma construção, o primeiro movimento é completado com algum sucesso, já que G.H. não consegue se livrar da experiência que viveu e a levou a um impasse e ao questionamento e flexibilização de sua moralidade, o que configurou um estado supostamente mais livre. Como proposta e como movimento, foi realizada a passagem da rigidez moral à moral mínima. Como força oposta, o impasse, característico do segundo estado, menos moral, desconfia de que tenha havido realmente um movimento, e sugere que a desconstrução não passa de uma idealização de uma construção. Este impasse acompanha toda a narrativa e faz com que qualquer conclusão (encadeamento de idéias e, portanto, estrutura finita) seja questionado. A tentativa de G.H. de se desconstruir para dizer-se passa a ser, enquanto diz, a construção que versa sobre uma desconstrução seguida de uma construção.

${ }^{17}$ Só há realmente paradoxos no mundo pré-verbal quando ele é observado de um ponto de vista. Completamente inserido no mundo pré-verbal, da experiência irrefletida, o sujeito não teria categorias que se contrapusessem para perceber situações paradoxais. Mais que isso, inserido na pura existência, sequer há um sujeito, instância necessária para haver um ponto de vista. 
Para Freud, a tríade de ideais culturais - ordem, beleza e limpeza - é fundamental na internalização da cultura pelo indivíduo. Ordem, beleza e limpeza formariam uma série de valores e significados para o indivíduo que o ajudariam a conviver em sociedade. No entanto, na civilização, que não é ideal, os ideais sociais entram por vezes em conflito com os objetivos expressos pelo Princípio do prazer: obter um máximo possível de prazer e afastar-se o mais possível do desprazer. É desse conflito que nasceria, para Freud, o malestar da civilização. Em A Paixão Segundo G.H., o conflito é expresso pelos valores e significados de G.H. antes do seu encontro com a barata, pelos valores e significados após a experiência, e pelo caos destituído de valores durante a experiência.

Evidentemente, a beleza, a limpeza e a ordem ocupam uma posição especial entre as exigências da civilização. ${ }^{18}$

A relativização do movimento de desconstrução da moral e as possibilidades de construção a partir de um solo preparado por esta desconstrução é o que será aproximado a seguir.

\section{2 - aqui e ali}

Do ponto de vista da razão ${ }^{19}$, todo o romance $A$ Paixão Segundo G.H. acontece (se move) em torno da tensão existente entre os domínios da moral e do neutro. Nessa tensão, moral e neutro podem ser substituídos por diversas classificações mais ou menos equivalentes, expressas por outras palavras. Ainda assim, não é simples concretizar demais essa tensão em elementos da narrativa que simbolizem apenas um ou outro campo. Reformulando: não há dois personagens, dois lugares, dois tempos, dois pontos de vista que configurem inquestionavelmente e sempre os pólos moral e não-moral da tensão fundante da narrativa. O pólo não-moral, o da existência não significada, talvez possa ser localizado próximo da barata. O pólo moral, no entanto, especificamente humano, não

\footnotetext{
${ }^{18}$ Freud, S. "O Mal-estar na civilização" In: Os Pensadores: Freud (v.39). São Paulo: Abril Cultural, 1978.

${ }^{19}$ É importante que se diga que qualquer classificação (ou ordenação ou generalização ou separação ou distanciamento) feita será feita sempre do ponto de vista da razão (ou de uma razão). Mesmo um ponto de vista só pode existir no domínio da razão. No domínio da não-razão, um todo amorfo, inclassificável, não há diferenciação entre sujeito e objeto, o que seria necessário para o estabelecimento de pontos de vista.
} 
pode ser separado do não-moral. Tudo o que é significado (moral) é, ao mesmo tempo, ou em outro tempo, também não significado. O humano em G.H. é tanto moral quanto nãomoral.

De acordo com seu modo mais próprio, literatura é linguagem e, assim, signo. Quando a proposta dessa literatura é o retrato do que não é ela, o impasse se apresenta inevitável. A linguagem, organizada, que pretende retratar ordem e não-ordem, convive sempre com a necessidade de ser e não ser ela mesma. No domínio da arte, o impasse é levado a um extremo interessante. Estivesse a ordem retratando também a ordem, a literatura se daria no campo do enigma. Bastaria ao leitor seguir caminhos lógicos do texto para significar a obra de algum modo (possivelmente diferente da significação imaginada pelo autor, mas isso importa pouco. $\mathrm{O}$ fato é que a linguagem que não pretende sair do domínio da ordem, da moral, funciona como um enigma, ou seja, uma proposição moral organizada a ser desvendada).

Mas não, a literatura de Clarice Lispector pretende a ilógica configuração do informe, a construção do nunca construído. Em sua proposta, a narrativa da personagem G.H. depende da existência simultânea de ser ordem e ser não-ordem, ainda que necessariamente submetidas à ordem que é o texto construído. A incongruência lógica, assim, depende de um pacto adicional entre leitor e obra, o que faria com que a obra fosse para o leitor, além de enigma (necessário à decodificação do texto), algo a ser apenas contemplado sem a expectativa de uma solução (mistério).

Surgem da possibilidade deste pacto duplo nem sempre acertado entre leitor e obra - a obra simultaneamente como enigma e mistério - relações entre leitores e Clarice Lispector comumente encontradas, por exemplo, nas salas de aula de Literatura Brasileira. Há um primeiro modo de ler Clarice Lispector - o do leitor a quem bastam os enigmas, cujos significados do mundo e da literatura são um simples desvendar, um leitor cujo discurso, modo como organiza o que leu, tende às construções interpretáveis, discurso que não inclui a dúvida sobre si nem sua possível relação empática com texto - para o qual a obra de Clarice seria uma construção falha na medida em que o mistério, insolúvel, foge da ordem lógica. Clarice Lispector parece excessivamente religiosa, ou excessivamente irreal, ou excessivamente louca. De outro lado, uma segunda leitura comum é feita por aqueles que encontram em Clarice Lispector (e especificamente em A Paixão Segundo G.H.) a possibilidade de não buscarem um significado, se não quiserem, por se sentirem 
confortáveis com as possíveis leituras místicas (ou míticas, ou religiosas) da obra. Esse segundo leitor destaca-se do mundo da ação e mantém-se no mundo da contemplação do mistério, não se entusiasma com as possibilidades de intervenção dele no significado da obra (o que pode ser sinal de sua falta de disposição para intervir no mundo que o cerca, ou de sua descrença em suas possibilidades de intervenção).

Uma terceira leitura é aquela em que o lugar da narração de A Paixão segundo G.H. é algo próximo da fronteira entre mistério e enigma, entre moral e não-moral, o que faz do pacto entre leitor e obra algo um pouco mais complexo. Mais do que isso, o lugar da narrativa pede para ser tratado às vezes como enigma, às vezes como mistério e, muitas vezes, para ser tratado como mistério e enigma ao mesmo tempo, o que dá especificidade ao contrato entre leitor e obra. O leitor deveria, assim, estar apto a oscilar entre (1) o caminho do trabalho científico desvendador, (2) o caminho do culto ao misterioso, da admiração ante ao mágico e (3) ter a específica capacidade de manter-se em ambos os caminhos ao mesmo tempo. ${ }^{20}$

Deriva-se dessa terceira possibilidade de leitura que o lugar da narrativa clariceana é próximo da consciência do impasse, lugar no qual os opostos são igualmente presentes. Pode ser uma incongruência lógica, mas se dá no âmbito da arte (ou da vida), desde que o acordo entre obra (mundo) e leitor (consciência) seja assim acertado. Do leitor, são pedidos o distanciamento, próprio ao enigma (postura científica, racional), e a aproximação, o envolvimento, próprios ao mistério (postura religiosa, mítica). Associada a outros aspectos do livro, esta postura de aproximação e afastamento pode ser vista como um elemento de construção trágica e relida como a coexistência da perspectiva apolínea (distância) e da não-perspectiva dionisíaca (aproximação) associadas.

A arte épica é uma arte "apolínica", como diz o termo estético; pois Apolo, o que atinge longe, é o deus do remoto, da distância, da objetividade, o deus da ironia. (Thomas Mann) ${ }^{21}$

\footnotetext{
${ }^{20}$ Uma observação salta então frente a esses pactos sistematizados entre leitor e obra. Podem ser eles também construções a serem negadas por outras construções. Para estar mais em acordo com a cadência do texto clariceano, esse pacto é construção e será, ele também, destruído se for visto como prescrição ou dogma. Embora seja uma generalização que aproxima PSGH de alguma tradição literária brasileira, como comentário, a escolha de Clarice por uma literatura que se nega é a escolha de Clarice por uma literatura que se nega.

${ }^{21}$ Mann, Thomas. "A Arte do romance" In: Ensaios. Perspectiva, p.16.
} 
Como diz Pasta Júnior, em um ensaio sobre o Grande sertão: veredas ${ }^{22}$, que se adapta bem, em diversos aspectos, a $A$ Paixão segundo G.H., "não há um só nível de sentido no Grande sertão que não responda a essa fórmula-base, que constitui assim o desenho interno de cada um de seus temas e motivos". Por "essa fórmula base", Pasta se refere à coexistência de enigma e mistério como "um mesmo princípio organizador" do texto. Segundo o ensaio, tal característica, que se mescla com uma série de outras, seria comum a diversas obras capitais da literatura brasileira. No texto de Clarice Lispector, o paradoxo é básico desde a aproximação de palavras de sentido oposto (nível dos pequenos elementos) até as sucessivas negações de qualquer conclusão (parcial) tirada na narrativa. Como diz o ensaio de Pasta Jr., a impossibilidade de síntese dialética é estrutural, não sendo superada ao longo de toda a narrativa ${ }^{23}$.

A impossibilidade de síntese dialética entre elementos opostos inconciliáveis aponta, assim, para a paralisação, o que é certamente uma possibilidade de leitura de grande parte da obra de Clarice Lispector. O impasse é, portanto, o lugar eterno da narrativa, sem que haja superação definitiva. O tempo não é uma flecha apontada exclusivamente para uma direção, mas a sucessão de um conjunto de possibilidades que podem se repetir. E se repetem. Dar significação à existência (ser moral) é inevitavelmente humano e paralelo à existência não significada (amoral). Não há um itinerário possível que siga exclusivamente por um dos (des)caminhos (ordem ou caos). Ser humano é ambos os pólos, construir e destruir (construir e reconstruir).

Há, vale lembrar, uma evolução inicial pela qual passa a personagem G.H. antes de se estabelecer no impasse (que parece ser definitivo). A G.H. anterior a sua experiência epifânica não é apenas humana, é excessivamente humana, como exemplifica a imagem da mulher com três pernas. A perda de uma das pernas simboliza, como já foi dito, o

${ }^{22}$ PASta JR., J.A. "O Romance de Rosa - temas do Grande sertão e do Brasil". In: Novos Estudos - CEBRAP n.55, nov. 1999, pp.61-70.

Neste ensaio de Pasta Jr. encontram-se diversos outros elementos aplicáveis a A Paixão segundo G.H. que podem fazer uma aproximação entre Clarice Lispector e a tradição literária brasileira.

${ }^{23}$ Exemplo de afirmação e negação sem superação é o significado dado por G.H. ao gesto extremo de colocar a barata na boca. Num primeiro momento, ela considera o gesto do desprendimento máximo, símbolo e afirmação de sua liberdade, de ter-se livrado de qualquer moral. Em seguida, volta-se ao mesmo fato e o vê como heroização, como supervalorização do gesto, o que seria o contrário do desprendimento. As palavras "máximo" e "símbolo" já são, elas mesmas, pertencentes ao modo lógico, classificatório, do ser.

Outro exemplo da impossibilidade de movimento de G.H. é a resolução de, depois de todo o percurso da narrativa para estabelecer-se no impasse e para estabelecer o impasse como seu lugar próprio, desistir e sair para dançar. Sua dúvida é então a escolha da cor do vestido. O impasse, ou o princípio ético de liberdade é, ele-mesmo, posto em dúvida (neste caso, afirmado como impossibilidade apesar de, ao mesmo tempo, ponto de chegada desejado. A única escolha possível naquele momento é a cor do vestido, bastante pequena em relação a mudanças imagináveis de maior abrangência). 
equilíbrio mais dinâmico desejável, ou seja, a aproximação do impasse. Assim, embora boa parte da narrativa se dê numa região onde parece não haver superação possível, uma proposta é formulada no livro e é a de afastar-se da moral excessiva e mover-se para a região do impasse, onde o ser humano não seria pouco nem excessivamente qualquer coisa, seria apenas humano. Este é o percurso ilustrado por grande parte do que foi dito na parte deste trabalho referente a ordem, limpeza e beleza. Existe, assim, uma passagem do humano excessivamente moral a um humano menos moral. Tal proposta (no estado de proposta, ainda não se definiu como alcançada ou não - alcançável ou não) aproxima Clarice Lispector não só da tradição literária brasileira (Pasta Jr.) como também das perspectivas humanistas mais difundidas no século XX, apoiadas na fenomenologia e no existencialismo.

Sobre o existencialismo em Clarice Lispector, muito já foi dito. Pode-se, no entanto, insistir em alguns pontos que ajudam a compreender a obra da autora. Do ponto de vista do existencialismo sartriano, a existência humana deve estar submetida a uma ordem que se baseia em aceitar a liberdade. É preciso esvaziar a consciência e assumir a liberdade. Isso poderia ser exemplificado justamente pela proposta clariceana de aproximação do impasse. Deste lugar, o impasse, a consciência teria se libertado de tudo o que é moral. Clarice representa o percurso de desconstrução da moral pela busca do eu mais desprendido do mundo, o menor eu que ainda não tivesse perdido sua identidade. Esse eu mínimo é representação razoável da consciência livre sartriana. A partir desse suporte mínimo, com máxima liberdade, o homem pode construir o que quiser e ser moral. A necessidade de permanecer no impasse (equilíbrio instável) é a de ter consciência de que a moral é construção, de que pode ser desconstruída. Nesse comprometimento com a liberdade, Sartre apóia a justificativa ética de seu existencialismo. Sem essa justificativa, a desconstrução pura e simples, a relativização absoluta de valores e significados, levaria à paralisação e à desordem. O comprometimento ético faz com que os atos sejam expressão de uma escolha moral.

Do mesmo modo, o movimento proposto por G.H. não é exclusivamente o da desconstrução (que se apresenta no livro como construção de desconstrução), mas o da construção a partir da consciência o mais livre possível. A idéia da desconstrução é a mais fácil de observar nas diversas leituras críticas do livro. A de construção a partir do impasse é que é mais rara. Vale notar ainda que parece haver uma tendência maior à crença na 
construção em Sartre (particularmente o Sartre mais alinhado aos movimentos políticos de esquerda) do que em Clarice Lispector. Em A Paixão segundo G.H., o impasse é condição permanente e, após cada construção, segue-se a desconstrução. A dúvida mesmo sobre o princípio ético sartriano é posta clara n'A Paixão. No livro, cada vez que uma proposta de construir é feita, logo é seguida da dúvida sobre possibilidades dessa construção.

O próprio processo de desconstrução moral (multifacetado em, por exemplo, desconstrução dos conceitos rígidos de ordem, beleza e limpeza) é tido, em determinado momento da narrativa, como uma construção da desconstrução. Em algum aspecto, isso é óbvio na medida em que o dito é discurso, necessariamente construção, o que configura sempre o impasse de se aplicar um sistema a algo que é necessariamente assistemático. As possibilidades de construção estarão sempre alicerçadas no nada, prontas a desmoronar. Precárias, as escolhas resumem-se no fim do livro, a escolher a cor do vestido que se usará para dançar naquela noite, nada mais permanente que isso, nem de maior abrangência.

Julio Cortázar diz algo interessante sobre quais seriam as bases fundantes de sua obra e de alguns de seus contemporâneos. Em sua Teoria do túnel ${ }^{24}$, Cortázar afirma que sua literatura é devedora de dois sistemas bastante difundidos no século XX: o existencialismo e o surrealismo. A associação das idéias de ambos ajusta-se bastante bem a Clarice Lispector e ajuda a entender sua obra.

Bem na superfície, pode-se traçar um caminho que coloca o existencialismo de Sartre como devedor de toda uma história filosófica baseada na razão. Esse existencialismo pode, assim, ser colocado no pólo da razão do impasse fundador da obra de Clarice e associado a uma cientificidade e a um pensamento positivo em relação às possibilidades racionais humanas que se associa ao desvendamento de enigmas. No outro pólo - o da exploração e da experiência com o misterioso -, o surrealismo. Existencialismo e surrealismo funcionam eles mesmos, se juntos, como tensão, embora não se excluam.

Segundo Pasta Jr., "quem quiser de fato ler o Grande sertão guardando fidelidade à demanda do livro, terá de lê-lo ao mesmo tempo com o isolamento e a distância que supõe o romance moderno e com o fusionamento e a participação que, no limite, só conhecem o

\footnotetext{
${ }^{24}$ Cortázar, J. Obra Crítica (v. 1). Rio de Janeiro: Civilização Brasileira, 1998.
} 
mito e o rito." ${ }^{25}$ Paralela a esta visão, é a seguinte, feita na introdução de Antonio Candido a $O$ Escorpião encalacrado, longo ensaio de Davi Arrigucci Jr sobre a obra de Julio Cortázar: "Este livro não é sobre Cortázar, pois pode ser lido também como se o assunto fosse a crise atual da arte e da literatura; ou antes, a crise dos meios tradicionais do que se chamava expressão artística e literária. Davi Arrigucci Jr. aborda o estudo da sua destruição, que pode ser ritual, mas pode também ser ontológica"26. "Ritual" e "ontológica" ajustam-se bem aos simultâneos "rito" e "distanciamento", que Pasta Jr. identifica com precisão em seu ensaio sobre o Grande sertão.

Da mesma introdução de Antonio Candido é "E não esqueçamos o modo certeiro pelo qual Cortázar é caracterizado como quem, nesta aventura perigosa, evita a direção do impossível e permanece na hesitação", o impasse.

O primeiro trecho de Antonio Candido citado acima aponta para dois caminhos, o que caracteriza uma possibilidade de organização. O que difere A Paixão Segundo G.H. da proposta de Julio Cortázar é a impossibilidade radical em G.H. de deixar o impasse, enquanto que para Cortázar a destruição das possibilidades absolutas do livro e da comunicação não é vista com tanta desconfiança e pessimismo. A desfetichização ${ }^{27}$ do livro é, para Cortázar, um avanço, uma evolução, enquanto que para G.H., se é um avanço, é contraditoriamente um avanço em direção ao impasse.

A comparação, vale dizer, é complicada na medida em que se está observando um ensaio assinado por um escritor (Cortázar) e as considerações de uma personagem (G.H.), que parecem se aproximar das idéias da autora. Desmente, no entanto, a identificação absoluta de G.H. com Clarice Lispector o fato de Clarice, apesar de viver sob o domínio do impasse, não ter se calado. Continua escrevendo e organizando seu pensamento. Não é o grito espasmódico de quem agoniza. É a fala organizada de um escritor. A armação trágica construída em torno do impasse e da necessidade de dizer é desfeita com a aceitação da dimensão humana (em acordo com as tentativas de deseroização). Continua-se escrevendo, continua-se existindo. Este passo adicional, o de deixar o objeto livro e aproximar-se do seu autor, faz-se necessário também porque a própria escritora deixa sua identidade no objeto. A introdução do livro, escrita em primeira pessoa, é assinada por C.L. e não por G.H. Clarice Lispector deixa ali índice de uma intenção de se fazer confundir com a

\footnotetext{
${ }^{25}$ PASTA JR., J.A. op.cit., p.62.

${ }^{26}$ Prefácio de Antonio Candido a Arrigucci JR., D. op. cit. (grifos meus)

${ }^{27}$ Caracteriza-se como fetiche a valorização do livro como objeto bem acabado em vez de o enxergar como resultado da prática (existência) de um sujeito no mundo.
} 
personagem narradora do livro: não assina o nome, mas apenas as iniciais, como as de G.H. É nessa introdução, também, que se encontra uma das grandes marcas de positividade do texto (contrapondo-se a grande parte do discurso do eterno impasse de G.H.)

[...] este livro nada tira de ninguém. A mim, por exemplo, a personagem

G.H. foi dando pouco a pouco uma alegria difícil; mas chama-se alegria.

C.L. (PSGH, 7)

No entanto, em A Paixão Segundo G.H., nada permanece como absoluto, nem mesmo a armação trágica que acompanha todo o enunciado de G.H. Também não continua absoluto o que desarma tal construção, que é a aceitação da dimensão humana, a aceitação do impasse, da derrota possível. O impasse se impõe até mesmo depois de sua desconstrução racional (parcial). O discurso organizado é também grito desesperado. A consciência do impasse, que é consciência, coexiste eternamente com o pólo não-moral e do descontrole. Assim, quando a consciência é acionada, o impasse se impõe e impossibilita o movimento de superação. Resta a possibilidade do movimento menos generalizável, ritual, por estar menos próximo do pólo da consciência livre e mais da submissão ao misterioso.

Desse modo, o que pode ser lido como aqui e ali, mistério e enigma, razão e nãorazão, tem de ser lido também como nem aqui, nem ali, pois o impasse desconstrói toda noção construída, e constrói e desconstrói e constrói..., inclusive a si mesmo.

Além dessa idéia inicial de simultaneidade de mistério e enigma, outras passagens do itinerário de Pasta Jr. em seu ensaio sobre Guimarães Rosa ajudam a ler Clarice Lispector. Por exemplo, na medida em que o impasse não impede completamente o movimento, apesar de não permitir o movimento linear, reto, de superações sucessivas. Permite, isso sim, um movimento, talvez pendular, que troca a paisagem e a existência local, mas que não elimina o impasse, que é questão de fundo. Não há acúmulo de experiência nesse movimento que permita a superação inequívoca e definitiva de um tempo passado.

Assim, o tempo em A Paixão segundo G.H. não é o tempo linear usual do romance do século XIX que se ajusta com facilidade a uma idéia de superações históricas, seja por evolução (lenta) ou revolução (abrupta). 
Retomo: A Paixão segundo G.H. e o existencialismo sartriano identificam-se, num primeiro momento, pela proposta de que o homem deve livrar-se de falsas certezas, de verdades transcendentes, e assumir sua existência terrena sem se enquadrar em sistemas de idéias inquestionáveis. Isso leva, em Clarice Lispector, ao impasse, e em Sartre à libertação do homem. Essa necessidade de não se colocar sob nenhuma regra específica (transcendente) abre uma possibilidade paradoxal e interessante: escrever não pode se submeter a uma prioridade estética, mas deve ser expressão de um indivíduo como modo de esse indivíduo existir. Isso faz com que o livro seja objeto questionável. No caso de Clarice Lispector, a questão foi abordada quando da dificuldade de enquadrar alguns de seus livros sob etiquetas inequívocas como romance, novela, conto, ensaio etc. A conclusão semelhante a essa, chegou-se pelo caminho da desconstrução dos critérios de beleza. O fato de o livro questionar-se enquanto livro (e todo o fetiche que o objeto e a obra de arte podem aglutinar) e fazer dele parte de uma existência é conclusão possível de premissas do existencialismo ao mesmo tempo que pode levar a formulações, como as do surrealismo, em que anulam-se as fronteiras da arte e da vida a fim de que tudo seja mecanismo para conhecer(-se). Neste ponto, existencialismo e surrealismo aproximam-se.

\footnotetext{
$\mathrm{O}$ aparente paradoxo desse louva-a-deus devorando sua própria fonte de prazer encobre a verdade de um divórcio entre dois homens só exteriormente semelhantes: o que existe para escrever e o que escreve para existir. $^{28}$
}

Este aniquilamento da distância entre livro e autor, pela supressão da necessidade de regras estéticas (que mediavam a relação), ajusta-se à aproximação de diversos narradores de Clarice Lispector a ela mesma, a escritora. O texto soa confessional. Ainda, como declarado pela própria escritora na conhecida entrevista a Julio Lerner (TV Cultura), em 1977, "eu escrevo para não morrer". Ou, nas palavras de Julio Cortázar, citadas acima, "o que escreve para existir". No romance tradicional, que pode ser sintetizado na obra e proposições literárias de Flaubert, o objeto livro era foco do fetiche, sendo que autor e sua existência ficavam num segundo plano. A arte se dava no objeto livro e não era comum que escritores questionassem esse distanciamento entre autor e obra.

\footnotetext{
${ }^{28}$ Cortázar, J. Obra Crítica (v. 1). Rio de Janeiro: Civilização Brasileira, 1998, p.35.
} 
Não é novidade afirmar que razões estéticas presidem a obra flaubertiana, na qual os valores éticos emanam naturalmente da personalidade do escritor e de sua temática, mas nunca aparecem intencionalmente inseridos numa trama. (p.32)

Segundo Cortázar, para alguns autores a sensação de que o meio de sua expressão (linguagem) limitaria as possibilidades de sua atitude artística era ou esquecida ao longo da vida (Balzac), ou permanecia como dúvida à parte da criação. Em sua própria obra, "nenhum dos escritores vocacionais parece reconhecer a dúvida que angustia o escritor contemporâneo, reflexo localizado de uma angústia generalizada do homem de nossos dias: "[...] de que talvez as possibilidades expressivas estejam impondo limites ao exprimível; que o verbo condicione seu conteúdo, que a palavra esteja empobrecendo seu próprio sentido."(p.39) Este escritor "rebelde" do século XX, que escreve como modo de existir, jamais esquece que a ferramenta que o ajuda a atravessar a barreira entre ele e o outro é a mesma que torna evidente a distância entre ambos. Enquanto ferramenta para uma travessia, a linguagem serve bem ao caminho da busca ontológica como tentativa de superação do impasse. Enquanto evidência da precariedade da comunicação, a linguagem aumenta a consciência do impasse e favorece sua perpetuação. Está formulado em outros termos o impasse clariceano, escrever como tentativa de superar uma distância e como evidência da existência dessa distância. Por outro lado, olhado pelo impasse, o movimento organizado, que supera e estabelece seqüências e superações, depende também ele de uma crença pré-racional na razão, o que configura uma construção apoiada em nada. 


\section{CAPÍTULO II \\ COMPASSO BINÁRIO}

A minha vida é como se me batessem com ela.

- Fernando Pessoa -

Após percorrer A Paixão segundo G.H. utilizando como guia a oposição sempre tensionada entre os pólos humano e não-humano (em algumas de suas diversas formalizações) do que G.H. descreve de sua experiência no mundo (geral) e com a barata (específico), pelas vertentes da desconstrução e da construção, proponho agora examinar em mais detalhes o que seria o sujeito clariceano em PSGH e como esse sujeito se relaciona com o mundo em que está inserido, quanto a suas possibilidades de ação nesse mundo - liberdade - e quanto a suas possibilidades de conhecimento.

Na medida em que a linguagem é:

(a) matéria com a qual se tece o livro,

(b) tema em PSGH, particularmente quanto a suas (im)possibilidades de expressar/elaborar a experiência heterodoxa, e

(c) fluxo entre sujeito e mundo

, a linguagem será observada em especial a fim de confeccionar um esquema que ajude a compreender G.H., sua experiência, seu mundo e seu relato (como expressão de um sujeito (ficcional) e como tessitura do livro por seu autor).

A questão da linguagem em Clarice Lispector parte da impossibilidade da mimese de uma experiência heterodoxa (inextensiva) no texto. Tal impossibilidade pode ser atribuída a diferentes aspectos da experiência em relação ao suporte textual e a sua recepção:

(1) Em primeiro lugar, qualquer experiência de curta duração, quando transposta em detalhes num texto, toma mais tempo do leitor do que sua duração original. A intensidade do fenômeno é transformada na extensão da descrição dos diversos influxos sensoriais, das parcelas do espaço, das sensações experimentadas etc. Essa é uma das características que diferencia os suportes mais dependentes do tempo, como a literatura, 
dos suportes menos dependentes do tempo, como a pintura, em que os sentidos (ao menos a visão, na pintura) podem ser acessados sem que a experiência precise ser distendida numa dimensão temporal. De modo geral, trata-se da diferença entre a duração da experiência narrada e a duração da fruição do texto ${ }^{29}$.

(2) Os fluxos entre sujeito e mundo são mediados por maneiras de recortar o mundo de modo que sejam apreendidos pelos diversos falantes. Se os modos de apreensão são culturalmente construídos, não há como garantir que tais modos de apreensão sejam os mesmos para todos os homens ${ }^{30}$. Assim, a informação codificada por um indivíduo não encontraria a chave de decodificação equivalente à que a codificou.

(3) No âmbito da vida ordinária, a linguagem funciona bem. O que garante essa funcionalidade é a fixidez dos significados das palavras em determinados contextos ${ }^{31}$ bem conhecidos pelos partícipes dos atos de comunicação. Quando, no entanto, o emissor quer expressar algo extraordinário, distante dos jogos de linguagem conhecidos pelo receptor, as palavras do emissor serão entendidas pelo receptor, que busca uma interpretação, como partes de algum outro jogo de linguagem conhecido de antemão. Neste sentido, por exemplo, é que Clarice faz a advertência na introdução do livro "Este é como um livro qualquer", prevendo que o leitor suporia um jogo de linguagem adequado a um livro qualquer. No entanto, algo um pouco diferente ("como um livro qualquer") pode ser esperado a partir deste anúncio.

(4) A rigidez das significações, determinada historicamente, impede que certa intuição seja expressa porque os recortes de mundo existentes e compartilhados não se encaixam em tal intuição. Assim, não é possível montar a intuição com os fragmentos (recortes) disponíveis. Em "A intuição filosófica"32, Bergson trata dessa impossibilidade. Resta então ao emissor organizar os fragmentos de modo a aproximar o que quer dizer. E organizar de novo os mesmos fragmentos disponíveis de outro modo. E de outro modo. As

\footnotetext{
${ }^{29}$ De modo menos específico ainda, a palavra, que é a ponte entre duas instâncias distantes, é a evidência da distância entre as instâncias. A palavra aproxima consciências distintas, tempos distintos, lugares distintos. Por outro lado, por preencher uma fenda, põe em evidência tal afastamento.

${ }^{30}$ Se são culturalmente construídos, não são como o sujeito transcendental kantiano. Neste caso, como os recortes que todos os homens fariam do mundo seriam os mesmos, a comunicação se estabeleceria com menos problemas do que para os sujeitos moldados historicamente.

${ }^{31}$ Wittgenstein chamou tais contextos de "jogos de linguagem". Estabelecem-se entre os participantes de cada jogo (situação) regras que garantem a funcionalidade no uso das palavras. Quando, por exemplo, um pedreiro grita a seu colega "tijolo", o segundo lança um tijolo para cima de um telhado, onde se localizava o primeiro. Nesse caso, ambos conhecem as regras do jogo, fundamentado na finalidade localizada de enviar tijolos para cima de uma laje.

Wittgenstein, L. Investigações Filosóficas. São Paulo: Abril Cultural, 1984.

${ }^{32}$ Bergson, H. A Intuição Filosófica. Lisboa: Colibri, 1994.
} 
peças montadas funcionam como imagens imprecisas do que se quer dizer. Dizer "não é x, não é y, não é $z, . . . "$, ainda que não configure a expressão positiva da intuição, aproxima a intuição em negativo diversas vezes pois afirma x, y e z como imagens antes de negá-las. Enxerga-se simultaneamente a positividade da aproximação (quase é) e sua negatividade (quase (=não) é).

Nesse caso, a rigidez que garante a comunicação nas situações ordinárias é que impede a comunicação do não-ordinário proveniente da experiência íntima.

Como observação, há em PSGH pelo menos uma referência à mudança do sistema de significação baseado em palavras:

Mas o que hoje é feio será daqui a séculos visto como beleza, porque terá completado um de seus movimentos. (PSGH, 159)

(5) Se a intuição a ser comunicada tem como características essenciais a sua não formalização e a sua unidade, características que seriam necessariamente perdidas pela expressão em palavra, a palavra não é meio satisfatório para expressá-la. Expressá-la não é possível. A intimidade do sujeito e o mundo são separados por uma fenda que impede que se misturem e se confundam. No universo clariceano (o que inclui G.H.), a percepção dessa separação regulamentar é dada pela idéia intuitiva da não-separação, da integração, proveniente dos momentos epifânicos recorrentes na obra da autora.

Mendilow $^{33}$, em sua longa reflexão sobre as estruturas do romance, comenta o romance moderno e suas declaradas impossibilidades:

[...] impressões instáveis, vacilantes, inconsistentes, que se queimam e se extinguem com a nossa consciência delas. ${ }^{34}$

Temos acesso apenas ao mundo já expresso em palavras, já recortado. Não existiria mais a experiência, mas um ponto de vista sobre ela.

Poderia qualquer língua fornecer palavras e arranjos suficientes mesmo para sugeri-las?

\footnotetext{
${ }^{33}$ Mendilow, A.A. O Tempo e o Romance. São Paulo, Cultrix/EDUSP, 1974.

${ }^{34}$ Richardson, Dorothy cf. MendiLow, A.A op.cit., p.57.
} 
O romance, então, pelas limitações de seu meio, nunca pode atingir a realidade, a vida, a verdade ou qualquer outra dessas abstrações "muito carregadas".

Tudo que tem sido dito e conhecido no mundo está em linguagem, em palavras [...] os significados das palavras mudam com os pensamentos das pessoas. Então ninguém conhece nada com certeza. Tudo depende da maneira como algo é expresso. ${ }^{35}$

De modo geral, todas as possíveis causas, aqui listadas, da indizibilidade do indizível, estão presentes em PSGH, confundem-se em alguns pontos, e são, cada uma, mais ou menos centrais conforme avança o enunciado. A impossibilidade (1) não se atém às diferentes configurações dos seres, nem como membros de grupos sociais, nem como individualidades. Fosse apenas essa a impossibilidade de transmissão de uma experiência, poder-se-ia abandonar o livro como meio de transmissão do que se quer dizer e montar um mecanismo que reproduzisse as condições originais - por exemplo, montar um quarto como o de G.H., colocar uma barata no armário e guiar a experiência. No quartolaboratório idealizado, o leitor estaria sujeito a diversos influxos vindos do mundo e não seria diferente de G.H. ao apreender tais influxos. A questão técnica, determinada pela estrutura da linguagem, é dizer a intensidade do que foi experimentado sem utilizar categorias pré-existentes, tendo como meio apenas a seqüência linear e temporal do discurso. É uma proposta fracassada desde o princípio, mas há diferentes maneiras de fracassar.

Entre as possíveis concepções de linguagem que abarcariam as afirmações de G.H. sobre o assunto, uma característica necessária é a de a linguagem se submeter a uma finalidade, de ela funcionar a princípio como ferramenta. O que faz o uso da linguagem ser adequado, ou não, é sua funcionalidade. Em diversas passagens do livro, acompanhando sua tentativa de se livrar de sua parcela excessivamente humanizada, G.H. (Clarice) se refere à necessidade de evitar a finalidade, ou faz a observação de que a G.H. anterior à experiência era excessivamente ligada à finalidade. A defesa dos valores ideais (o belo, o organizado, o limpo, o moral, o bom, enquanto fins morais) estaria assim subordinada à realização ou não das intenções dos sujeitos envolvidos em cada interação lingüística. A

${ }^{35}$ Mendilow, A.A. op.cit. , pp.57-58. 
estrutura complexa da cultura seria, desse modo, a cristalização dos diversos fluxos lingüísticos inicialmente vinculados a uma finalidade clara e local. A moral instituída seria a representação sistemática do interesse de indivíduos, o que pode representar o interesse de grupos. É desse modo que G.H. pode perceber-se a princípio livre, com algum poder por, ao mesmo tempo, (1) ser moral e (2) pertencer ao grupo social cujos interesses tal moral parece servir. Por outro lado, desconfia dessa moral, que lhe dá poder mas que é obedecida com rigidez sem ter sido escolhida. A palavra nasce como intermediária entre o sujeito e o cumprimento de seus desejos básicos, e se solidifica de modo a aperfeiçoar a ferramenta que permite que a finalidade seja atingida com mais eficiência pelos diversos membros de um grupo. Conforme aumenta, no entanto, a estrutura ganha uma infinidade de novos elementos, o que pode dificultar a identificação das finalidades. A palavra ganha então uma segunda dimensão necessária. $\mathrm{O}$ indivíduo cumpre um procedimento por subordinar-se a uma finalidade que não é conhecida. Age-se em função de um bem maior, de valores ideais, de um sistema moral baseado em fundamentos desconhecidos. Assim, aproximam-se a moral, a solidificação dos significados e valores, e a finalidade. Indivíduo e finalidade estão separados por uma estrutura lingüística gigantesca que impede que, utilizando-se da palavra, o indivíduo enxergue a finalidade da ferramenta que ele utilizou.

Para a minha anterior moralidade profunda - minha moralidade era o desejo de entender e, como eu não entendia, eu arrumava as coisas, foi só ontem e agora descobri que sempre fora profundamente moral: eu só admitia a finalidade (PSGH, 22)

O que eu estava vendo naquele monstruoso interior de máquina, que era a área interna de meu edifício, o que eu estava vendo eram coisas feitas, eminentemente práticas e com finalidade prática. (PSGH, 36)

E eu - eu via. Não havia como não vê-la. Não havia como negar: minhas convicções e minhas asas se crestavam rapidamente e não tinham mais finalidade. Eu não podia mais negar. Não sei o que é que eu não podia mais negar, mas já não podia mais. E nem podia mais me socorrer, como antes, de toda uma civilização que me ajudaria a negar o que eu via.(PSGH, 76) 
Estabelecidas as noções de certo e errado (e todos os modos de avaliar as práticas humanas em função dos ideais morais vigentes), o homem age diretamente submetido a este balizamento, certo e errado, e indiretamente submetido a uma finalidade qualquer desconhecida que delega poderes ao balizamento. Esse modo controlado de agir pode não trazer recompensa imediata ao indivíduo. A recompensa é adiada. $\mathrm{O}$ indivíduo age na expectativa de que haja uma finalidade desconhecida que o recompense. Esse sentimento de espera por uma recompensa futura desconhecida é outra tópica clariceana em PSGH: a esperança. Identificam-se assim esperança, finalidade e moral, que se constroem na dimensão do tempo e do humanizado, e se opõem à experiência revelatória de G.H. com a barata, acontecida em um aqui, agora, uno e ilimitado, um instante-já. (como definiu Clarice Lispector em Água Viva).

E uma desilusão. Mas desilusão de quê? se, sem ao menos sentir, eu mal devia estar tolerando minha organização apenas construída? Talvez desilusão seja o medo de não pertencer mais a um sistema. No entanto se deveria dizer assim: ele está muito feliz porque finalmente foi desiludido. O que era antes não me era bom. Mas era desse não-bom que eu havia organizado o melhor: a esperança. De meu próprio mal eu havia criado um bem futuro. (PSGH, 13)

A esperança de quê? Pela primeira vez eu me espantava de sentir que havia fundado toda uma esperança em vir a ser aquilo que eu não era. A esperança - que outro nome dar? - que pela primeira vez eu agora iria abandonar, por coragem e por curiosidade mortal. A esperança, na minha vida anterior, teria se fundado numa verdade? Com espanto infantil, eu agora duvidava.

Para saber o que realmente eu tinha a esperar, teria eu antes que passar pela minha verdade? Até que ponto até agora eu havia inventado um destino, vivendo no entanto subterraneamente de outro? (PSGH, 58) o que sai da barata é: "hoje", bendito o fruto de teu ventre - eu quero a atualidade sem enfeitá-la com um futuro que a redima, nem com uma esperança - até agora o que a esperança queria em mim era apenas escamotear a atualidade. (PSGH, 83) 
Vale notar que é no domínio das ferramentas que lhe são dadas que G.H. pode elaborar sua experiência, ainda que tenha e queira dar a essas ferramentas uma finalidade pouco usual. É dentro do domínio da palavra que G.H. se vê adiando algo, estendendo um discurso para falar do inextensível, do que é agora. ${ }^{36}$

Estou adiando. Sei que tudo o que estou falando é só para adiar - adiar o momento em que terei que começar a dizer, sabendo que nada mais me resta a dizer. Estou adiando o meu silêncio. A vida toda adiei o silêncio? mas agora, por desprezo pela palavra, talvez enfim eu possa começar a falar. (PSGH, 22)

Devido à rigidez do sistema de linguagem (que é sistema de valores e significados), que não se molda a ponto de se ajustar à experiência pouco ortodoxa, e devido ao desconhecimento das finalidades últimas desse sistema é que G.H. (C.L.) se vê na necessidade de estabelecer uma linguagem que seja menos que uma linguagem, que seja como uma massa fluida (água viva, geléia viva) que endurece espontaneamente sobre a memória (também a afetiva) de sua experiência, de modo a construir um relato satisfatório. Para isso, G.H. estabelece sua tentativa de desconstrução de conceitos, de aquisição de liberdade em relação ao sistema lingüístico disponível e compartilhado. É dúbio, no entanto, que tal processo de libertação seja apenas uma desconstrução. Enquanto relato, ele é certamente a construção de um relato. Enquanto vivência, pode ser, como suspeitou G.H., a heroização de uma construção rígida artificiosa que se diz desconstrução ou liberdade.

Já que tenho de salvar o dia de amanhã, já que tenho que ter uma forma porque não sinto força de ficar desorganizada, já que fatalmente precisarei enquadrar a monstruosa carne infinita e cortá-la em pedaços assimiláveis pelo tamanho de minha boca e pelo tamanho da visão dos meus olhos, já que fatalmente sucumbirei à necessidade de forma que vem de meu pavor de ficar indelimitada - então que pelo menos eu tenha a coragem de deixar que essa forma se forme sozinha como uma crosta

\footnotetext{
${ }^{36}$ Do mesmo modo, Rodrigo S.M. se vê adiando a narrativa de Macabéa por não encontrar no sistema discursivo o modo e o tom de dizer algo muito mais sutil. Em A Hora da estrela, há ainda a separação de classes entre narrador e personagem, o que dá especificidade à incapacidade de o sistema lingüístico do narrador dizer o narrado.
} 
que por si mesma endurece, a nebulosa de fogo que se esfria em terra. E que eu tenha a grande coragem de resistir à tentação de inventar uma forma. ${ }^{37}$ (PSGH, 15)

Como foi dito anteriormente, o sujeito clariceano é usualmente separado do ser do mundo que o cerca. Ele experimenta um não-pertencimento que é fundante de boa parte da obra da escritora. Assim separado, ele não tem como conhecer diretamente esse ser. $\mathrm{O}$ sujeito tem acesso apenas ao fenômeno, ou seja, ao produto da interação entre o ser, as capacidades sensoriais e os modos de recortar e apreender o mundo. Perde assim o sentido qualquer especulação sobre uma causalidade ${ }^{38}$ objetiva. Ou melhor, perde o sentido o homem supor ter acesso a essa causalidade última, aos fundamentos do ser. Resta ao sujeito sua tendência por organizar os fenômenos, observar padrões de repetição e criar critérios baseados na experiência.

Levantei-me enfim da mesa do café, essa mulher. Não ter naquele dia nenhuma empregada iria me dar o tipo de atividade que eu queria: o de arrumar. Sempre gostei de arrumar. Suponho que esta seja a minha única vocação verdadeira. Ordenando as coisas, eu crio e entendo ao mesmo tempo. (PSGH, 33)

Procedimento semelhante é utilizado quando o sujeito se vê envolvido por uma experiência heterodoxa, imprevista, epifânica e rara, como o encontro de G.H. com a barata. Resta ao sujeito a vontade de organizar, acompanhada da impossibilidade de utilização, neste caso, dos critérios prévios. Por ser raro, o fenômeno heterodoxo não se confirma e reconfirma pela repetição. São diferentes, nesse aspecto, dos procedimentos usuais em que as causalidades estabelecidas se confirmam com tanta freqüência que ganham status de verdade. Se minha sensação de sede é minimizada diariamente, há anos, pela ingestão de água, dizer que água provoca o fim da sede tem comprovação empírica diária. Ainda, se, além de raro, o fenômeno é de natureza diferente dos demais, falha mesmo a aproximação desse fenômeno por experiências semelhantes anteriores, já que não

\footnotetext{
${ }^{37}$ Inventar uma forma seria artificioso, seria recortar a experiência em formas pré-concebidas. A tentativa, porque a existência de uma forma parece irrevogável, é que a forma surja sem a interferência das formas já existentes.

${ }^{38}$ A causalidade em PSGH relaciona-se com a idéia de temporalidade, que será discutida e ilustrada a seguir.
} 
há semelhanças suficientes. No caso das epifanias clariceanas, a brecha entre sujeito e mundo desaparece pelo curto período em que o sujeito experimenta (intui) a indivisibilidade do ser, supostamente sem a mediação de seus modos usuais de apreensão. O sujeito sente-se incluído no mundo que, como regra, o exclui e em relação ao qual é heterogêneo.

Em PSGH, G.H. sequer sabia dessa brecha que a separava do ser. Vivia em conforto, aparentemente sem tensões que a aborrecessem demais. A experiência com o uno é que faz evidente a brecha, a separação, o mistério, e que torna tensa sua vivência logo após o encontro com a barata. ${ }^{39}$ Há outras narrativas de Clarice Lispector em que a fenda ontológica genérica é figurada em um não-pertencimento mais específico. Por exemplo, o não-pertencimento da menina ruiva de "Tentação"40 - num mundo de morenas, loiras e negras - que se transforma em pertencimento quando ela encontra o cachorrinho de pêlo vermelho; ou a mulher de "O Búfalo"41, que é alheia a sua própria agressividade. Para G.H., sua solidão ontológica é figurada também na sua solidão como indivíduo numa sociedade: mora só, não teve filhos nem qualquer relação que não pudesse ser chamada de pré-clímax, de adiamento, de promessa, de esperança e se opusesse à experiência do instante-já, de sua sensação de pertencimento no ser do mundo. ${ }^{42} \mathrm{~A}$ barata não é apenas um outro/mesmo num critério específico (cabelos vermelhos) ou a evidência da falta de algo determinado (ódio). Ela é a chave para o vislumbre de um não-pertencimento fundante e tão genérico quanto possível do homem em relação ao mundo.

A linguagem é, então, grosso modo, um sistema de símbolos, com valores e significados a eles associados, que, em determinadas situações, têm ou não funcionalidade, isto é, atendem ou não a uma intenção de um ou mais indivíduos envolvidos nesse jogo específico de linguagem ou de indivíduos não envolvidos nesse jogo (neste caso, os envolvidos podem não conhecer a intenção, a finalidade de sua própria prática). Num sistema bem formado, apesar de a finalidade do jogo não se completar em si, garante-se

\footnotetext{
${ }^{39}$ Não se pode excluir a idéia de que, de tão heterodoxas e informuláveis, as epifanias das personagens, ainda que se repitam, podem ser esquecidas até que outra epifania abale o razoável equilíbrio ordinário. Como da experiência epifânica sobra pouco ou nada, a epifania é sempre novidade ao sujeito que não tem ferramentas para lidar com ela.

${ }^{40}$ Lispector, C. "Tentação" In: A Legião estrangeira. São Paulo: Rocco, 1999.

${ }^{41}$ Lispector, C. "O Búfalo" In: Laços de Família. .São Paulo: Rocco, 1999.

${ }^{42}$ Não se pode esquecer que, devido a sua classe social, G.H. era incluída na sociedade. No entanto, sua inclusão baseava-se em moralidade e, necessariamente, adiamento (esperança), sendo qualitativamente diferente da inclusão ontológica experimentada. O adiamento é índice suficiente para se afirmar a parcialidade da inclusão.
} 
que a soma dos efeitos dos jogos de linguagem produza o efeito final desejado. No entanto, no meio da complexidade dos sistemas, e pelo fato de os jogadores desconhecerem as intenções não locais da estrutura, é possível que os jogadores modifiquem o jogo minimamente, julgando que não será prejudicada a efetividade da ação lingüística. É possível também que determinadas práticas sejam esquecidas e que o encadeamento dos jogos não mais se dê. É possível que determinados comportamentos (moral: moros (latim), costumes) sejam valorizados ou desvalorizados apesar de suas finalidades não terem mais validade. O homem associa a determinados discursos (fragmentos lingüísticos) um valor positivo (ou negativo) e espera (esperança) por uma recompensa futura (finalidade) que, nesses casos, não existirá. O sistema apresenta-se firme e aparenta continuidade quando é, na verdade, formado por fragmentos pouco conexos, como uma corda, rígida, formada por uma infinidade de pequenos pedaços de fibra devidamente torcidos e tensionados.

Desse modo, resta no sistema de linguagem/cultura uma infinidade de fragmentos inúteis associados a virtudes (a bom, a belo, a limpo...). A cultura torna-se um rígido sistema cheio de ruínas, de fósseis, que regem idéias e comportamentos, que moldam as possibilidades humanas e que fazem os homens agirem, por respeito ao código moral, de determinado modo.

Mas algo da natureza terrível geral - que mais tarde eu experimentaria em mim, algo da natureza fatal saíra fatalmente das mãos da centena dos operários práticos que havia trabalhado canos de água e de esgoto, sem nenhum saber que estava erguendo aquela ruína egípcia para a qual eu agora olhava com o olhar de minhas fotografias de praia. (PSGH, 36)

Por enquanto, hoje, eu vivia no silêncio daquilo que daí a três milênios, depois de erosado e de novo erguido, seria de novo escadas, guindastes, homens e construções. Eu estava vivendo a pré-história de um futuro. Como uma mulher que nunca teve filhos mas os terá daí a três milênios, eu já vivia hoje do petróleo que em três milênios ia jorrar. (PSGH, 107) Mentalmente tracei um círculo em torno das semi-ruínas das favelas, e conheci que ali poderia ter outrora vivido uma cidade tão grande e límpida quanto Atenas no seu apogeu, com meninos correndo entre mercadorias expostas nas ruas. (PSGH, 108) 
Essas ruínas de cultura seriam, assim, limitadores inúteis das possibilidades humanas. Em outras palavras, o homem abre mão de alguma liberdade em favor de uma esperança abstrata, de uma finalidade desconhecida, sistematizada em uma cultura fragmentada. Os comportamentos não apenas são regidos por finalidades desconhecidas que servem a sujeitos vivos, supostamente sujeitos com poder na sociedade, mas também por finalidades que serviriam a interesses de sujeitos mortos e intenções anacrônicas. A rigidez e a grandiosidade desse sistema moral são figuração das dificuldades de G.H. para formular uma experiência não ortodoxa, isto é, sem finalidade.

Ainda sobre a concepção de que se atribui causalidade a partir da experiência, da repetição, da funcionalidade e da memória ${ }^{43}$, o conhecimento científico-racional só ganha legitimidade quando confirmado empiricamente. Mesmo a ciência acaba por se apoiar na crença da regularidade dos fenômenos, na idéia de que é razoável dizer que A->B para um fenômeno A que é sempre observado acoplado ao fenômeno B. A ciência (e tudo o que se apóia nela) é, assim, um sistema de crenças. O raciocínio e o trabalho científicos são seqüências de etapas que resultam em produtos empíricos. O trabalho e o raciocínio científicos se submetem, também, ao critério de funcionalidade. A razão especulativa e a metafísica devem perder valor, segundo esta concepção sobre as relações causais, por carecerem de comprovação empírica. As causas últimas, inacessíveis ao homem, não deveriam ser objeto de questionamento na medida em que a razão pura, independente da experiência, não é fonte de conhecimento. Isso faz do livro e da elaboração da experiência em palavras algo secundário em relação à experiência e aumenta a sensação de impossibilidade da escrita, a não ser que se considere a escrita (ou a leitura) como experiência ela-mesma.

Mais ainda, a razão e o trabalho científicos, neste caso, se igualam ao trabalho e à razão ritual, por estarem ambos sujeitos ao critério da funcionalidade.

Soube o que não pude entender, minha boca ficou selada, e só me restaram os fragmentos incompreensíveis de um ritual. (PSGH, 16) ${ }^{44}$

\footnotetext{
${ }^{43} \mathrm{O}$ homem percebe os fenômenos $\mathrm{A}$ e $\mathrm{B}$, que se repetem na mesma seqüência $\mathrm{A}$, $\mathrm{B}$. O homem atribui uma causalidade A->B e a guarda na memória de modo a esperar que, ocorrido A, logo ocorra B.

${ }^{44}$ Há um sentido adicional para "ritual", que não elimina o sentido aqui apresentado, que será discutido mais a frente. Trata-se do ritual como o modo de o humano cumprir seu destino, o ritual como a máscara que faz o homem especificamente humano.
} 
Deste ponto de vista, toda a temática do mágico e do ritual ganham força em PSGH. O romance, na sua totalidade, por exemplo, é a passagem de um personagem, de um ambiente cotidiano a um ambiente diferente, especial, onde se toma contato com parcelas de si que antes estavam escondidas, com a ingestão final de uma porção de matéria que é parte de um todo vislumbrado. Do mesmo modo é o ritual de tomar a hóstia, na igreja, após a confissão dos pecados.

Dado, assim, que a causalidade é uma categoria que o sujeito atribui a determinadas seqüências de fenômenos a partir da experiência, da repetição e da crença de que a mesma seqüência será observada no futuro: como é construída em PSGH a dimensão da temporalidade?

A temporalidade relaciona-se com a causalidade por ambas se submeterem aos critérios empíricos. A temporalidade, a princípio, é como um ritmo que bate subjacente ao mundo, que acompanha a sucessão dos fenômenos, ou marca a ausência dessa sucessão (apreendida muitas vezes pelo viés do tédio).

Porque o tédio é insosso e se parece com a coisa mesmo. E eu não fora grande bastante: só os grandes amam a monotonia. O contato com supersom do atonal tem uma alegria inexpressiva que só a carne, no amor, tolera. Os grandes têm a qualidade vital da carne, e, não só toleram o atonal, como a ele aspiram. (PSGH, 141)

O tempo é a pulsação que acompanha a existência do (no) mundo, subjacente às aparências, e que não aponta para uma posição específica (perspectiva teleológica), mas apenas se repete: pulsa. É o ritmo do neutro.

A Paixão segundo G.H. não é um livro que se vincule a uma idéia tradicional de livro bem formado. Boa parte de suas possibilidades de sedução está na dissolução das formas que possam ser reconhecidas como formas. Não se trata da dissolução efetiva de todas as formulações, já que das formas depende a comunicação, mas a simulação (neste aspecto, sim, bem formada) dessa dissolução. O leitor tem que ser enganado, levado pela mão pelo caminho que é também descaminho, pelas constantes destruições e construções das guias, e mudanças de sentido. A aceitação pelo leitor, ao longo do percurso de G.H., de uma parada ou de outra e de sua sucessiva negação é índice de que o leitor inclina-se a 
dissolver, índice de sua própria dissolução, mas não pode deixar de ser, enquanto literatura, ordem que simula a indiferenciação. Nessa simulação dissimulada, não há lugar para a conceitualização a não ser que pelo lado negativo. Assim, a regra (as exceções a confirmam) é que temporalidade, tanto quanto outras categorias usuais da ontologia, do romance ou da vida, não se apresenta afirmativamente como forma notável em contraste com o fundo, mas como forma (ou figura) que nega a forma usual e que se afirma enquanto negação. Nega a forma usual ao mesmo tempo que simula ser não-forma. A idéia de tempo se apresenta, então, por vestígios de uma temporalidade (assim como a idéia de causalidade). Temporalidade e causalidade ligam-se no texto pela maneira como os fragmentos desse texto se sucedem e por algumas imagens que figuram sucessões de eventos.

Das possíveis divisões de PSGH, a mais evidente é a divisão em partes que poderíamos chamar de capítulos. Dentro de cada capítulo, é desenvolvida a narrativa, com alguma autonomia em relação às demais partes. A interface entre os capítulos (isso é bem marcado) se dá de um modo em que a última frase de um é a primeira frase do capítulo seguinte. Assim, a autonomia entre as partes se articula em um ponto comum. Dentro de um capítulo, o movimento da narrativa segue um curso até determinado ponto, a última frase. Desse ponto, segue-se para um outro, não causado pelo anterior, apenas antecedido. A narrativa não segue um caminho linear, ela se adia, se enrola e desenrola, volta. A sucessão de capítulos não aponta para um lugar (uma síntese), é feita por caminhos, mas também por descaminhos. A temporalidade e a causalidade apresentadas a partir dessa característica da capitulação não é muito mais que um ritmo pulsante. Um fenômeno segue o outro, mas não por uma lógica acessível. Dessa lógica última do mundo temos apenas a experiência, a transfiguração da lógica em fenômeno. Além disso, seria especulação.

Da mesma maneira, no misterioso mural na parede do quarto de Janair, os traços têm uma característica semelhante à capitulação:

$\mathrm{O}$ traço era grosso, feito com ponta quebrada de carvão. Em alguns trechos o risco se tornava duplo como se um traço fosse o tremor do outro. (PSGH, 39)

Um traço não é a decorrência lógica do anterior segundo um planejamento. $\mathrm{O}$ traço é o descontrole (não um descontrole qualquer, mas um que se vincula ao traço anterior pelo 
ponto comum, a intersecção entre os dois traços-tremores). Dessa imagem, é possível também derivar a idéia de pouca autonomia do sujeito em relação ao mundo, já que seu controle sobre as decisões (liberdade - traço) está submetido a instâncias não controladas (sujeição - tremor).

Logo no início de seu enunciado, quando vai se referir a sua experiência (ainda não narrada), G.H. refere-se a seu encontro com a barata como um tremor, uma anomalia no que a civilização propunha como regularidade:

Não compreendo o que vi. E nem mesmo sei se vi, já que meus olhos terminaram não se diferenciando da coisa vista. Só por um inesperado tremor das linhas, só por uma anomalia na continuidade ininterrupta de minha civilização, é que por um átimo experimentei a vivificar a morte. (PSGH, 15)

Isso faz faz da causalidade objetiva uma lógica inacessível aos dedos grossos da civilização.

Essa atenção à idéia de não haver uma causalidade bem comportada, de $\mathrm{A}$-> B não ser uma relação regida por uma necessidade - fosse esta proveniente do homem (pois este não controla os fenômenos) ou do mundo (pois o homem não tem acesso às causas últimas num mundo objetivo) - é concretizada no livro também na sucessão de movimentos e paradas da narrativa. Os movimentos de busca por uma verdade são sucedidos pelo reconhecimento de que não havia verdade objetiva apreensível, mas atribuição do valor de verdade. Então move-se para outro destino a partir do fracasso anterior, repetindo o ciclo. Tanto no modo de finalizar e começar os capítulos, quanto nos traços-tremores do mural e no ritmo de movimentos e paradas da narrativa, as relações temporais e causais são sucessões de eventos cuja lógica, se há uma, está além da compreensão humana, são parte de um mistério poucas vezes intuído (apenas nas epifanias).

Quanto aos capítulos e à temporalidade, uma última observação: o último capítulo acaba em seis travessões, exatamente como começa o primeiro capítulo. Pode-se tomar esse fato como a representação de um tempo cíclico, em acordo com os demais padrões rítmicos do texto, que retomam seu princípio após algum movimento. O ciclo como imagem de temporalidade limita também as possibilidades humanas. Não é viável a busca de um cume absoluto evolutivo - os cumes são locais e seguidos de depressões. Não há 
também uma evolução clara, apenas a sucessão de estados diferentes no mundo e no sujeito. As conquistas, de modo geral em PSGH, não são definitivas. Nada garante que a terceira perna que se perde não será ganha em momento posterior. Os vínculos entre fatos sucessivos são tão obscuros e inusitados (como um encontro com uma barata ou com um cego mascando chicle levar a uma iluminação) que, num estado posterior, o sujeito pode mesmo desconfiar de sua memória sobre o que acabou de acontecer, como o que relata G.H. sobre sua experiência do dia anterior. Os diferentes estados pelos quais o sujeito passa se desconhecem e fazem com que o sujeito, ele-mesmo, seja dependente da obscura causalidade do mundo, representação das sucessões sem evolução, seja por acúmulo de experiência, seja por reflexão. O ciclo dá uma perspectiva trágica à condição (ou natureza) humana. O homem segue um destino cujas relações causais desconhece. O homem se repete como condição/natureza/destino trágico nessa oscilação entre saber/não saber, comunhão/separação, satisfação/insatisfação, movimento/parada, neutro/palavra etc.

De concepção semelhante é o tempo no conto "A Quinta história"45. Nesse conto, um mesmo fato é narrado de diferentes perspectivas não excludentes, "porque nenhuma delas mente a outra". O conto insiste num processo que é o mesmo e é o novo, um ritmo simples em que a narradora explica a morte das baratas que lhe apareceram no apartamento. Publicado em época próxima à publicação de PSGH, "A Quinta história" tem diversos pontos comuns com o romance. Diz a narradora numa das histórias "Estremeci de mau prazer à visão daquela vida dupla de feiticeira. E estremeci também ao aviso do gesso que seca: o vício de viver que rebentaria meu molde interno. Áspero instante de escolha entre caminhos que, pensava eu, se dizem adeus, e certa de que qualquer escolha seria a do sacrifício: eu ou minha alma. Escolhi. E hoje ostento secretamente no coração uma placa de virtude: "Esta casa foi dedetizada" ". Nesse trecho está bem clara a condição humana dupla: a ordem (eu) e a desordem (alma). Nessa história, a vontade de matar é ao fim acoplada à explicação por um valor ideal de limpeza, a casa estava limpa de baratas. $\mathrm{O}$ ciclo induzido pela forma do conto que é vários contos em seqüência é também expresso na alternância entre motivos (da alma e da desordem) e explicações (do eu, da palavra e da ordem). O ritual inicial (organizado) do preparo do veneno, semelhante ao de contar uma história por noite, é seguido por uma noite de perdição e morte. E essa vida dupla se renovaria: "Eu iria então renovar todas as noites o açúcar letal? como quem já não dorme

\footnotetext{
${ }^{45}$ LispectoR, C. "A Quinta história" In: A Legião Estrangeira. Rio de Janeiro: Rocco, 1999.
} 
sem a avidez de um rito?" A concepção geral de "A Quinta história" difere um pouco de PSGH por conseguir contar histórias, todas elas verdadeiras, sem que uma negue a outra, sem que nada precise ser negado. Há mais aceitação da falibilidade do discurso, todos são possíveis, não necessariamente falsos. Em PSGH, cada seqüência afirmativa é seguida de uma negação. Não é um fato contado de cinco ou mil e uma maneiras, mas um fato contado de maneira nenhuma. Em "A Quinta história", a palavra se afirma; em PSGH, a palavra se nega.

De volta a PSGH, o tempo é um pulsar, um ritmo que apenas existe, se repete.

Era a alta monotonia de uma eternidade que respira. (PSGH, 91)

A temporalidade é, de modo geral, cíclica, o que contraria a idéia de esperança e salvação. As relações causais são, em primeiro lugar, obscuras aos homens, como fundamento, apreensíveis somente enquanto fenômenos (resultados). A partir disso, a idéia de historicidade ganha duas características. A primeira é que não pode haver história como evolução, acúmulo e superação. A história, se extrapolada a partir da vivência de G.H., é a sucessão de momentos pouco conectados entre si. A idéia de acúmulo é construída de modo negativo, já que o que se acumula, muitas vezes, é cultura fossilizada, restos inúteis de significados e valores que limitam a liberdade humana. A segunda característica é a organicidade do momento histórico. O conjunto de regras organizadas é rígido e difundido. Os sujeitos estão submetidos a ele. Quanto à linguagem, por exemplo, faceta da cultura, a difusão e aceitação de um mesmo sistema garante o fluxo de informação ordinária entre os indivíduos. Por outro lado, o sistema lingüístico pode não acolher bem alguma informação extraordinária, como a experiência íntima de G.H. e não dar conta de dizê-la. ${ }^{46}$ História é, então, a sucessão de momentos históricos orgânicos. Tal sucessão apresenta em relação à cultura, ainda que de modo negativo, a idéia do acúmulo. Já as idéias de superação e evolução não condizem com as linhas principais da temporalidade em PSGH. Uma temporalidade cíclica (e uma causalidade obscura, apreendida enquanto fenômeno e não enquanto causa), não dá ao homem e à história perspectivas afirmativas de evolução e

\footnotetext{
${ }^{46}$ Apesar de, diversas vezes, a dificuldade de inserção do sujeito e de sua experiência poderem ser vistas como conseqüência de uma separação ontológica entre indivíduo e mundo, G.H. (C.L.) trata, em outras passagens, mais concretamente, a dificuldade de utilização da linguagem como uma rigidez do sistema de significados e valores de determinado momento histórico.
} 
superação. A necessidade da confirmação empírica (ainda que a experiência não dê acesso a uma Verdade) elimina desse modo a possibilidade de transcendência - nem mesmo o futuro pode transcender (diferenciar-se em valor - melhorar) o presente. Apenas é outro. $\mathrm{O}$ mundo, como apreendido por alguns personagens de Lispector, é uma sucessão de revoluções (tremores) sem sujeito.

Por fim, o tempo que avança é o modo como o homem apreende os eternos instantes-já do ser. Borges definiu esse tempo de maneira clara, num conto, o que ajuda a ilustrar a fratura fundante entre homem e mundo (gatos e baratas são mundo).

[...] pensou, enquanto alisava o pêlo preto [de um gato], que aquele contato era ilusório e que estavam como separados por um cristal, porque o homem vive no tempo, na sucessão, e o mágico animal, na atualidade, na eternidade do instante. ${ }^{47}$

João Adolfo Hansen escolhe o mesmo animal para descrever a atemporalidade de Macabéa - "como um gato, não tem distanciamento, sendo atemporal"48.

Nessa concepção, o tempo passa a ser um modo como o homem organiza sua experiência e, cíclico ou não, é produto humano sobre seu estar no mundo e não um dado do mundo em si.

Este claustro para o homem (a falta de certezas, integração e perspectivas de mudanças controladas) elimina, como discurso, uma parte das possibilidades efetivas do homem no mundo. Uma questão que se coloca então é: quais são as possibilidades de G.H. (o ser humano emblemático no livro) no mundo? Onde estaria e de que tipo seria a liberdade? Antes, porém, é preciso discutir uma aparente incongruência entre (1) esta postura empirista, que na apreensão e organização do mundo se submete à critérios de efetividade ${ }^{49}$ e na razão se fortalece por algum ceticismo (rejeição a qualquer dogmatismo, ou qualquer afirmação categórica baseada em razão especulativa e não submetida a verificação empírica), e (2) o movimento desesperado na busca de uma explicação para uma experiência ortodoxa, o que se parece mais com a busca por uma verdade transcendente do que com a busca por uma solução que funcione quando aplicada a um problema circunstancial.

\footnotetext{
${ }^{47}$ Borges, J.L. "O Sul" In: Ficções. Globo: Rio de Janeiro, 1984, p.164.

${ }^{48}$ Hansen, J.A. "Uma estrela de mil pontas" In: Língua e Literatura, São Paulo, (17), 1989, pp. 107-122.

${ }^{49}$ Como na discussão anterior, que torna indiferentes a ciência e o ritual.
} 
Pois bem, a busca de um transcendente absoluto parece ser em PSGH a extrapolação máxima da vontade de organizar, característica humana. Se organizar é generalizar a experiência circunstancial de modo a poder utilizá-la numa outra circunstância, a prever um fenômeno B a partir de um fenômeno A, a transcendência absoluta seria uma regra que diria que a partir de A sempre obtemos B. O absoluto seria também uma supra-organização que permitiria dizer a experiência.

Como, no livro, nenhum absoluto sobrevive ao exame do anti-dogmatismo, a sucessão de conclusões e dúvidas sobre tais conclusões só cessa porque o livro acaba (considerando que o último capítulo acaba como o primeiro começa - o ciclo -, esse ritmo dado pelo "sim não sim não" não cessa nunca, e é imagem própria ao pulsar inerente ao ser quando observado). A postura cética (anti-dogmática), que não deixa que um juízo possa ser generalizado $\left(e p o c h e^{50}\right.$ ) permeia o livro tanto em relação à razão (impossibilidade de afirmar algo categórico baseado em especulação puramente racional) quanto em relação à experiência (impossibilidade de afirmar algo categórico baseado na apreensão do mundo pelos sentidos). O que faz a narrativa andar, no entanto, é a busca da generalização e a especulação que, logo em seguida, serão submetidas à epoché nessa cadência de aquis e alis.

A insistência é o nosso esforço, a desistência é o prêmio. A este só se chega quando se experimentou o poder de construir, e, apesar do gosto de poder, prefere-se a desistência. (PSGH, 176)

Então, o que move a enunciação é um percurso interno ao sujeito, "A trajetória somos nós mesmos." (PSGH, 176), a peripécia interna, uma busca racional, submetida a confirmação empírica, e regulada por uma instância, que pode ser dita cética, cuja atuação é não generalizar conclusões locais. Esta instância cética evita que o sujeito estabeleça um caminho bem determinado, permanecendo na busca racional sem se engajar firme em uma conclusão parcial. A enunciação tenta não parar em moralizações, que são como a já descrita linguagem cristalizada. Esta linguagem paira entre os sujeitos e permite que eles

\footnotetext{
${ }^{50}$ Epoché é uma palavra grega, muitas vezes associada ao pensamento cético pirrônico, que significa a suspensão do juízo. A razão especulativa não deve ser fundamento para a formação de juízos. No caso em que um juízo não é acessível pela observação, ele deve ser suspenso. Aceitam-se as limitações das faculdades humanas. Isso não significa que, na prática, uma ação não seja feita. $\mathrm{O}$ juízo sobre essa prática, apenas, é que fica suspenso.
} 
interajam, na busca por um suporte anterior mais íntimo e genérico onde, possivelmente, pudessem ser apoiadas as escolhas e regras morais. Como a vigilância cética não deixa que esta moral íntima se estabeleça, a peripécia continua sem que o sujeito (a personagem) se constitua para agir no mundo. Quando, no fim do livro, G.H. decide sair e dançar, não é por ter encontrado um suporte moral firme, mas por apoiar sua decisão na desistência da procura.

A narrativa (enunciado) é, desse modo, a tentativa de constituir um sujeito moral autêntico antes de ele ir ao mundo, o que não se dá pela via da construção (elaboração em linguagem). G.H. não descarta, no entanto, que haja um princípio anterior a essa construção, aceita-o como mistério e admite não formulá-lo afirmativamente. O princípio anterior é íntimo e informulável (para que possa não se submeter às determinações do discurso conceitual)..$^{51}$

Volta-se então à questão de onde estariam as possibilidades de constituição do sujeito diante do mundo, em PSGH, se não pela busca de um princípio fundador para dialogar com as decisões morais humanas. Duas possibilidades iniciais surgem talvez da vontade de dar sentido único ao percurso interior de G.H. (sua tentativa de formulação do disforme).

A primeira dessas interpretações é a supervalorização do fato de, no fim de seu enunciado, G.H. apaziguar grande parte das tensões que motivaram o texto, logo que dá o mistério como aceito. Esta perspectiva ignora a alternância, ao longo do livro, entre (a) momentos de aceitação (de uma interpretação) e parada, e (b) movimento em busca de uma nova interpretação/formalização. Ignora também os indícios de temporalidade cíclica e valoriza uma parcela do enunciado (o fim da leitura) que, num ciclo, é tão posterior quanto anterior a todo o resto. Do mesmo modo que a idéia de história não tem vínculo necessário com a idéia de evolução e de superação, o estado de G.H. do fim do livro não é claramente melhor que o inicial.

\footnotetext{
51 "A moralidade. Seria simplório pensar que o problema moral em relação aos outros consiste em agir como se deveria agir, e o problema moral consigo mesmo é conseguir sentir o que se deveria sentir? Sou moral à medida que faço o que devo, e sinto como deveria? De repente a questão moral me parecia não apenas esmagadora, como extremamente mesquinha. O problema moral, para que nos ajustássemos a ele, deveria ser simultaneamente menos exigente e maior. Pois como ideal é ao mesmo tempo pequeno e inatingível. Pequeno, se se atinge; inatingível, porque nem ao menos se atinge. "O escândalo ainda é necessário, mas ai daquele por quem vem o escândalo" - era no Novo Testamento que estava dito? A solução tinha que ser secreta. A ética da moral é mantê-la em segredo. A liberdade é um segredo." (PSGH, 86-87, grifos meus)
} 
De outro lado está a interpretação que foca a impossibilidade de afirmações categóricas e definitivas e trata essa impossibilidade como a impossibilidade e a inviabilidade da existência humana. Junta-se a isso a sujeição do homem a (a) uma ideologia sócio-historicamente determinada e (b) sua determinação enquanto matéria (genericamente, tanto quanto uma pedra) ou enquanto animal (menos genericamente, tanto quanto uma barata), e as impossibilidades humanas caminham para o absoluto. O que diferenciaria o homem do animal seria que, além de sua submissão ao orgânico, o homem se submeteria também a uma ideologia (ou a uma moral).

Nenhuma dessas visões a respeito de PSGH abrange a dinâmica da enunciação, suas diferentes paradas e movimentos. É preciso, no entanto, esclarecer alguns pontos antes de esboçar uma interpretação um pouco mais abrangente. ${ }^{52}$

A Paixão segundo G.H. é um guia de salvação ou a porta para uma perdição?

Se dermos às possibilidades humanas de escolha e ação o nome genérico de liberdade, não é difícil elencar diferentes possibilidades e, esquematicamente, diferenciar as liberdades. O quanto um pensamento ou comportamento é determinado pela condição orgânica ou pela condição ideológica do homem, por suas circunstâncias locais e específicas ou por sua condição ontológica, tudo isso pode se relacionar com a palavra liberdade.

A princípio, o enunciado é movido por uma vontade de dizer e pela procura do lugar em que dizer seja possível. No caminho, conforme possibilidades são vislumbradas e negadas enquanto liberdade, é construída uma trilha de impossibilidades investigadas, até então consideradas potenciais de liberdade.

O descontrole da experiência que escapa não encontra recipiente adequado na palavra. No começo, a busca pela palavra é também o adiamento da busca e o vislumbre das impossibilidades. A busca pela palavra que diga é antes a busca por um poder dizer, por um fazer-se sujeito em contraposição a sujeitar-se ao orgânico e à história. Mas o caminho da enunciação passa sempre pela sujeição à palavra (convenção social); o caminho da enunciação de G.H., pelo reconhecimento de si no outro, isto é, o caminho do

\footnotetext{
${ }^{52} \mathrm{Ou}$ : é preciso, no entanto, esclarecer alguns pontos, o que já será a tentativa de uma interpretação mais abrangente, sem que apenas a idéia final seja a interpretação: "Não se trata de ouvir uma série de frases que enunciam algo; o que importa é acompanhar a marcha de um mostrar." (HeIDEGGER, M. "Tempo e Ser", In: $O s$ Pensadores. São Paulo: Abril Cultural, 1980.)
} 
fazer-se sujeito, passa pelo sujeitar-se e por se reconhecer objeto (na identificação com a barata).

O primeiro movimento de libertação é a busca por uma palavra autêntica, que não seja apenas a reprodução de discursos. Se, por um lado, a busca dessa linguagem se relaciona com a eliminação da esperança (na medida em que não se ata a uma finalidade futura, muitas vezes desconhecida), põe em evidência a finalidade, ainda que local e menos mediada. A princípio, este seria já um ganho de liberdade pois desvincula (mesmo que parcialmente) o indivíduo do claustro ideológico do tempo histórico. É possível dizer, de outro modo, que esse movimento de PSGH é a tentativa de se fazer menos moral, libertando-se das convenções compartilhadas, dos valores e significados fixos e vigentes, na busca por um princípio mais íntimo e autêntico. ${ }^{53}$

Por um lado, esse movimento se completa e permite, ao menos, que exista uma enunciação com uma aparência bem característica, a qual muitos leitores consideram "estranha". E ser estranho, o modo de dizer, é uma maneira de não estar obviamente submetido a uma moral (compartilhada e rígida).

Por outro lado, não há como ter certeza de que não se está sendo moral, ainda que de um modo diferente e mais discreto. Se se está submetido a uma moral que molda pensamentos, a aparência de diferente pode ser um arranjo novo dos mesmos moldes.

G.H. oscila entre estes dois pontos, o de se achar mais livre e o de se achar mais vinculada aos moldes históricos e à palavra inautêntica. Caminha e busca uma organização enquanto a liberdade lhe parece acessível. Agita-se e reclama (o enunciado caminha) procurando a liberdade enquanto não se sente livre (ou se agita como que na disposição de livrar-se da desagradável idéia de não ser potente).

Sempre oscilando entre a idéia de estar pensando e a idéia de estar reproduzindo discursos (seguindo um programa cujo princípio é inacessível), G.H. depara-se com uma porção, também sua, que não é pensamento. A identificação com a barata dispara, entre tantas outras conseqüências, a identificação de G.H. com sua existência orgânica-animal. Depara-se com princípios, como a sobrevivência do indivíduo e da espécie, com sua agressividade fundadora, com o fato de não ter tido filhos. Frente a mais essa impossibilidade, pois estaria seguindo o plano para o qual teria sido programada como animal, paralisa-se mais uma vez por não encontrar suas possibilidades.

\footnotetext{
${ }^{53} \mathrm{Na}$ parte III deste trabalho, essa revolta contra a linguagem petrificada será entendida como a via romântica segundo a qual o texto de Clarice Lispector se desenvolve.
} 
Coloca-se mais uma vez em movimento até perceber especificidade em ser humana, mulher, e não barata. Paralisa-se cada vez que vê reificada a conclusão que era antes seu caminho. Aceita ser humana, com as limitações da história e da biologia, com sua possível (e jamais garantida) liberdade espremida entre porções enormes de impossibilidades, liberdade que é enquanto sensação de liberdade e que não é enquanto sensação de impotência.

Encara-se então como matéria, como parte de uma pulsação neutra que é o mundo sendo. Tão livre quanto uma pedra. No mundo em que as coisas apenas são, liberdade faz bem pouco sentido. A consciência de que se existe, de que algo existe, é dado empírico do homem no mundo, não de um mundo em si. O exame do ser (o mundo) em si não dá qualquer idéia do que seja liberdade ou consciência. Liberdade e consciência são outra coisa.

Em um mundo assim formulado, sem transcendências, o fato de existir uma outra coisa, que não o mundo material, ou seja, a consciência, vai contra a lógica razoável de quem observa mas não se percebe observando. $\mathrm{O}$ mundo existe e é observado. $\mathrm{O}$ homem tem consciência de que existe e de que existe o mundo, pelo menos enquanto fenômeno. $\mathrm{O}$ fato de haver consciência é como uma mágica. Por serem essencialmente diferentes, não se pode dizer nada da consciência a partir da investigação do mundo (ser), a não ser dizer, por experiência, que há uma consciência. É nesse ponto que um grande impasse se dá em PSGH. A consciência é o que difere o homem de todo o resto observável. O homem vê o mundo. A barata é o mundo.

Sartre, neste ponto, fundamenta seu existencialismo formulando que o homem é liberdade, que a consciência (nada) é radicalmente livre para escolher. Não elimina a existência de todos os condicionantes ideológicos e físicos, mas dá ao homem toda a liberdade de escolha. Para Clarice, em PSGH, a questão neste ponto ganha um discurso um pouco diferente. Como na citação de Heidegger (emprestada de Schelling) que afirma que o último fundamento (fundo $=$ Grund) é um abismo (sem fundo $=$ Abgrund), não há especulação racional ou empírica que garanta a eliminação do mistério de o homem ver (consciência) e não simplesmente existir (ser). A conclusão clariceana, mais ao gosto da epoché do cético que ao da razão afirmativa de Sartre, é a de que a escolha mais fundamental do viver é aceitar ou não o mistério. 
No âmbito desse mistério está também o postulado unívoco de Sartre de que consciência é liberdade. Para Clarice, dentro dos sucessivos caminhar e parar, os compassos se organizam em torno da aparência de liberdade (como no postulado sartriano) e de observação. Se o homem se sente livre, pode construir; se se sente apenas um observador de um mundo que pulsa a sua revelia, é impossível se envolver numa busca (organizada ou não) que não seja a da própria liberdade. Sem desvelar o mistério, o homem oscila entre a sensação de ser livre e a sensação de apenas observar, sendo ambas (liberdade e sujeição) igualmente possíveis do ponto de vista da razão. Liberdade não passaria de um conceito cujo valor é atribuído pelo homem.

Sem que um dos dois pólos perdure, um ser humano como G.H. marca sua existência por um perambular que não insiste numa via, que não se vincula a um caminho sem que uma instância questionadora logo o impeça de se mover.

Assim, numa busca que começa com um não poder dizer, G.H. propõe uma liberdade que é seu discurso pouco vinculado a uma moral. Não conclui categoricamente que o discurso é livre mas nega a possibilidade de, seguindo a moral, produzir um discurso autêntico. Desse modo, autoriza seu discurso pela suspensão de um juízo: não é possível saber se se é ou não livre utilizando um sistema lingüístico que padroniza valores e significados. Ao menos, propõe um caminho, sua forma de discurso, que se não é livre, pode parecer livre. Discurso valorizado, G.H. vai de encontro a todas as impossibilidades do homem no mundo - submissão à história, à organicidade da matéria e a outras condições materiais, tais como ser impedida de sair do quarto pois a porta do guarda-roupa a impedia $^{54}$ - até chegar ao impasse fundador, o mistério sobre a liberdade de uma consciência no mundo.

Na minha clausura entre a porta do armário e o pé da cama, eu ainda não tentara de novo mover os pés para sair, mas recuara o dorso para trás como, se mesmo na sua extrema lentidão, a barata pudesse dar um bote eu já havia visto as baratas que de súbito voam, a fauna alada. (PSGH, 51)

\footnotetext{
${ }^{54}$ Num nível do texto, as impossibilidades locais como a clausura de um corredor fechado pela porta de um armário podem ser lidas também como figurações de uma impossibilidade humana mais geral, condição humana fatal.
} 
A impossibilidade de fundamentar o pensamento em qualquer instância que transcenda o indivíduo faz com que o discurso confessional seja a regra para os discursos possíveis. A amostragem para qualquer conclusão é o conjunto de impressões no sujeito de suas interações com o mundo, não o mundo ele-mesmo, e as relações causais levam sempre uma grande marca de dúvida devido ao desconhecimento das supostas leis de um mundo objetivo.

Do mesmo modo, não um fato objetivo mas uma impressão, a liberdade existe enquanto aceita-se e se tenta construir. É sensação de poder. Quando uma construção, apoiada em nada, incomoda, desconstrói-se.

G.H. vivia no último andar de uma superestrutura, e, mesmo construído no ar, era um edifício sólido, ela própria no ar, assim como as abelhas tecem a vida no ar. (PSGH, 68)

Mas, exatamente o lento acúmulo de séculos automaticamente se empilhando, era o que, sem ninguém perceber, ia tornando a construção no ar muito pesada, essa construção ia-se saturando de si mesma: ia ficando cada vez mais compacta, em vez de se tornar cada vez mais frágil. O acúmulo de viver numa superestrutura tornava-se cada vez mais pesado para se sustentar no ar. (PSGH, 68)

G.H., representante do gênero humano, é o pulsar, o ritmo desse ciclo de construir e desconstruir, de acreditar e duvidar, de caminhar com uma destinação e agitar-se aleatoriamente.

Dado o que foi dito até agora, há diversos fatores que separam a intenção de um formulador de discurso e a internalização de algo por um segundo indivíduo atingido pelo discurso do primeiro. As dúvidas sobre as causalidades no mundo fazem do discurso que se pretende estritamente lógico uma especulação inefetiva. Atingir uma segunda consciência por um discurso depende mais de movê-la de um estado de descrença que convencê-la por uma lógica. A lógica apóia-se no nada (o mistério) e, do mesmo modo que a ciência se iguala ao ritual por dependerem ambos de crenças e se submeterem ao critério da efetividade, o discurso racional clássico se iguala ao discurso passional. A medida da efetividade do discurso é o efeito produzido na audiência e não um critério de correção 
externo às circunstâncias desse discurso. Desse modo, o discurso clariceano em PSGH se reveste de ares de impossibilidade, nega o discurso, mas é discurso. Nega uma certa organização, mas é organização (pois é discurso). Finge ser essencialmente negação, enquanto afirma-se como discurso. E, se toca a audiência, é porque extrapolou a condição de organização, despertou identificação e estranhamento, e foi, de algum modo, efetivo. Não se encaixa bem nas categorias genéricas da ficção, ou do texto (romance, novela, ensaio, etc), mas tem efeito. Assim, mais retórica (quer convencer, comover) que argumentação (quer estar correto). Foca no efeito produzido e não no objeto em si. Utiliza relações lógicas e ordens pré-estabelecidas (ou não) apenas na medida em que esses artifícios lhe são úteis no acesso ao outro. A vida não é uma ciência.

A vida, meu amor, é uma grande sedução (PSGH, 61)

É pouco razoável não desconfiar de uma enunciação de quase duzentas páginas que se diz desesperada e figura uma aporia em boa parte de seu percurso. Há em PSGH uma série de procedimentos que permitem o desenrolar do enunciado e ajudam a fazer um texto extremamente organizado dar ares de desespero. O livro é a construção feita por uma escritora. Ela dá voz a uma personagem-narradora. É construção organizada de um desespero: "escreveu esse livro, no ano de 1963, e em pouco menos de um ano"55, não em uma tarde ou duas. O exame das estruturas do discurso do livro pode desvendar, então, alguns princípios organizadores, de algum modo negados pelo próprio discurso de G.H. O desabafo da personagem é expressão não de sua subjetividade desesperada, mas da subjetividade controlada de um autor (se é que algum controle - liberdade - é possível). Um discurso que nega as possibilidades de si mesmo não pode ter como foco a construção de si como uma obra no mundo. Ele aponta para fora de si, para a impressão de marcas numa consciência. A retórica clariceana em PSGH finge falar sozinha como jorro espontâneo quando é tentativa organizada de preencher a fenda que separa uma consciência do que não é ela, e de diminuir a solidão angustiante do homem (sem consolações categóricas e transcendentes) jogado no mundo.

Ainda como estratégia, o modo confessional do discurso, que reforça a idéia de solidão e isolamento, pode produzir, por identificação, a dissolução da idéia de solidão,

\footnotetext{
${ }^{55}$ GotlıB, N.B. Clarice - Uma vida que se conta. São Paulo: Ática, 1995.
} 
quando a audiência solidariza-se com o enunciado na sua solidão. Há integração a um grupo quando o solitário sabe que não é o único a ser só.

Como estratégia, então, de simulação do informe, o texto é construído em boa parte como negação. O que usualmente na literatura salta do fundo, a forma, afirma-se negandose. O artifício é negar o que se parecer com uma afirmação e dissolver a forma que ameaça enrijecer. Cada vez que o leitor reconhecer uma imagem, ela deve ser negada. Quando caminhar por si for possível - distanciando-se da falta, que é condição humana -, o chão deve ser retirado como lembrança para a falta de alicerces de qualquer construção. A aceitação final da falta de chão é o estado paradoxal da presença de um discurso sobre a falta.

A dissolução das formas é o projeto racionalmente irrealizável de a forma ser nãoforma. A palavra deve servir como isca ao que não é palavra.

Nos termos dos jogos de linguagem propostos por Wittgenstein, o leitor vai tentar interpretar o que lê de acordo com as regras dos jogos já conhecidos. Ao mesmo tempo, aprende a adaptar seus jogos à situação que vai sendo construída. Se o discurso pretende falar de algo diferente, se ele pretende convencer o leitor de que o que ele diz não é algo antes formalizado, o que lhe resta, dentro do domínio das formas, é ser um discurso que não se pareça com os discursos já conhecidos. Quanto aos jogos de linguagem, o discurso deve estar especialmente preocupado em estabelecer um novo jogo em vez de fazer com que um dos anteriores funcione bem. Nesse sentido, o adiamento da narrativa dos fatos em PSGH acompanha uma série de avisos de que o que se diz não é o que se quer dizer. Ainda, como o que se quer dizer é sempre heterogêneo em relação ao que se diz, a estratégia é estabelecer um jogo de linguagem que se apóie na idéia de, a fim de ser bemsucedido, não ser nenhum dos jogos de linguagem conhecidos. No limite, nega-se enquanto possibilidade. A partir dessa última negação, é preciso crer na não-linguagem, no que não foi dito, em uma comunhão não-verbal entre as consciências. Aliás, essa não é uma característica específica desse discurso, específico dele é deixar explícita a necessidade de crença. Como uma fenda separa o homem de tudo o que não é ele, tentar se comunicar apóia-se na crença de poder se comunicar. Como já foi dito, a liberdade não é uma constatação empírica nem algo derivável pela lógica, a questão da liberdade é dentro de um mistério que se pode acreditar de um modo (liberdade) ou de outro (determinismo). 
O non-sense em PSGH, ou seja, a falta de expansão lógica que abarque o absurdo da existência, é mais dado pela negação que pela afirmação de formas. Há em outras literaturas que tratam do(s) absurdo(s) da existência a formalização do absurdo: o homem que acorda inseto, o que vomita coelhos ou, mesmo na literatura de Clarice Lispector, as imagens mais bem formadas do cego que masca chicles, ou da menor mulher do mundo. ${ }^{56}$ O absurdo em PSGH é dado por um fato corriqueiro (uma mulher que se depara com uma barata) em que formas diretamente ligadas à narrativa (o quarto, o guarda-roupa, a cama, o apartamento, a barata, o retrato, a mulher) são poucas e cotidianas. Em A Metamorfose, por exemplo, o elemento estranho se forma: uma consciência que se vê associada a um corpo de inseto. Em PSGH, o absurdo se encontra na não-forma, ainda que apresentado pela palavra (forma).

Assim, diferente de outros textos próximos na tradição literária e nos seus temas, PSGH se afirma negando(-se). Não se trata da apresentação de um discurso non-sense, mas a afirmação pelo discurso de que há um non-sense. Cada sentido formado deve ser negado.

O texto de PSGH, que se assemelha a diversos outros textos de Clarice Lispector ${ }^{57}$, é, assim, ao mesmo tempo, formalização de um alicerce (discussão dos sustentáculos de um texto) e de uma construção sobre esse alicerce. E, tudo, sobre o mistério, que pode ser nada (os momentos de maior paralisação da personagem, nos quais fundamentação alguma parece possível) ou outra coisa, desconhecida (o sentimento de alguma possibilidade de construção).

De volta à dissolução das formas, PSGH se aproxima de algumas propostas surrealistas. O próprio gesto de provar a barata poderia ser derivado das propostas surrealistas de manter contato com parcelas menos conhecidas do homem pela experimentação do diferente. O discurso de G.H. se apóia, também, na tentativa de eliminar censuras da psique. Algo que se assemelha à proposta da escrita automática percorre todo o enunciado de G.H. na sua busca por uma linguagem mais autêntica, que expresse a intimidade da personagem e se submeta menos aos preceitos (moral) impostos (sugeridos) por uma sociedade. No entanto, no caso de G.H. e de A Paixão segundo G.H., o estranho não é a figuração de um boi numa sala de estar. É um algo, que seguindo muitos

\footnotetext{
${ }^{56} \mathrm{Na}$ ordem:

Kafka, F. A Metamorfose. São Paulo: Companhia das Letras, 2000.

Cortázar, J. "Carta a uma senhorita em Paris" In: Bestiário. Nova Fronteira, 1986.

Lispector, C. "Amor" In: Laços de Família. Rio de Janeiro: Rocco, 1998.

Lispector, C. "A menor mulher do mundo" In: Laços de Família. Rio de Janeiro: Rocco, 1998.

${ }^{57}$ Água Viva, "O ovo e a galinha", "A geléia viva", para citar exemplos dos mais próximos e conhecidos.
} 
dos padrões da linguagem convencional, não se resume a uma figura pouco usual, mas, de modo geral, à negação de diversas figuras usuais. A aparente proposta de escrita automática se dá, como idéia de G.H., em uma tarde, o que não corresponde à organização lógica de um livro que tomou meses de escrita de sua autora. O jorro de idéias de G.H. e seu tom confessional são simulação de um fluxo de consciência. O trabalho do artista não está, como poderia, no fato de sentar-se e se dispor a escrever seu fluxo de consciência enquanto este corre, mas em simular um fluxo de consciência que ocorresse sem que o artista se dispusesse a registrá-lo.

Esse esforço que farei agora por deixar subir à tona um sentido, qualquer que seja, (PSGH, 15) ${ }^{58}$

O novo jogo de linguagem de PSGH, se atingir seu objetivo, fará com que o leitor esteja atento à não-palavra em si mesmo ou no mundo, a partir da palavra isca, que será negada logo que a não-palavra morder.

Dentro deste discurso artificioso sobre algo que é não-palavra, alguns procedimentos se repetem e são significativos para o estudo do texto clariceano e dos efeitos produzidos. Esses procedimentos têm por objetivo a construção de um domínio em que se diz pela negação do que se diz.

Uma primeira estrutura recorrente em PSGH, já comentada, é uma sucessão de movimentos que culminam num grande não. Em primeiro lugar, afirma-se um valor ou significado (x) e se vai gradualmente negando-o ao se percorrer toda uma dimensão lógica desse valor, de $+x$ a $-x$, o que corresponde a toda a gama de possibilidades de existência quantitativa de x num fenômeno. Em seguida, afirmada a dimensão x (ainda que negada em cada parte), nega-se x, como dimensão, afirmando que o que se pretendia dizer era algo que não pode ser dito em função de $\mathrm{x}$. Um procedimento como esse tende a negar diferenças $^{59}$, o que faz com que o neutro, indiferenciado, seja afirmado na negação das diferenças. Essa estrutura é utilizada em diversos aspectos da narrativa, por exemplo, como já foi dito, na apresentação e posterior negação dos valores ideais (ordem, beleza e

${ }^{58}$ Além de diversas outras passagens já citadas neste trabalho sobre a busca de uma escrita mais adequada aos propósitos de descrever a experiência com a barata.

${ }^{59}+\mathrm{x}$ e -x são igualmente inúteis na afirmação do que se quer afirmar. +x e -x (limpo e sujo, por exemplo) tornam-se indiferentes 
limpeza). O belo, por exemplo, é apresentado pela imagem do apartamento de bom gosto, segundo critérios sociais. Em seguida, G.H. se dirige ao quarto da empregada (cuja porta dá para os fundos do prédio), representante do feio (não-belo). O movimento continua com o encontro com a barata. Percorrida toda a extensão da dimensão $\mathrm{x}=$ beleza, nega-se tudo pois o que se quer dizer não é classificável segundo essa dimensão. O neutro é indiferente quanto à beleza, não pode ser descrito como uma função dela.

[...] ah, não quero dizer que é o contrário da beleza, "contrário de beleza" nem faz sentido - o que sai da barata é: "hoje", bendito o fruto de teu ventre - eu quero a atualidade sem enfeitá-la com um futuro que a redima, $(\mathrm{PSGH}, 83)$

Pela apresentação e negação sucessivas de diversas dimensões, afirma-se algo que é negativo em relação a qualquer classificação, que não é função de nenhuma dessas dimensões e que é indiferenciável.

Também na ordem social, esta estrutura é encontrada. Janair e G.H. são a princípio apresentadas como opostas dentro de uma ordem social e extremos dentro de uma dimensão simples que vai de, por exemplo, patrão $(+x)$ a empregado $(-x)$. A dimensão é então negada quando G.H. reconhece que contingências as levaram a assumir uma ou outra posição e que, na verdade, responderiam, de posições diferentes, a uma mesma moral. Essa dimensão é negada mais uma vez quando se reconhece a identidade das duas enquanto mulheres. Negada uma terceira vez quando a indiferenciação atinge o ponto mais alto, quando tudo é matéria (viva ou não) e quando G.H. não se diferencia nem da barata, "vai acontecer o amor de duas baratas" (PSGH, 113), que, aliás, era antes identificada com Janair: "E agora eu entendia que a barata e Janair eram os verdadeiros habitantes do quarto" (PSGH, 49).

A grande negação se dá pela indiferenciação do sim e do não, pela aproximação de aparentes opostos. Um segundo procedimento, cujo sentido também aponta para a indiferenciação, é a apresentação direta de idéias opostas para denominar o mesmo fenômeno. Em geral, essa denominação paradoxal está associada à apresentação do neutro. Ela serve para relativizar o sentido das palavras e acentuar sua imprecisão. Ao mesmo tempo, cria uma possibilidade de se referir ao impreciso e indiferenciado. 
Como exemplo, as idéias deus/paraíso/anjo são utilizadas para denominar o neutro tanto quanto seus opostos usuais demônio/inferno. Em outros casos, a justaposição de idéias contraditórias é ainda mais evidente. Um adjetivo pode qualificar um substantivo de sentido oposto.

\section{[...] a mão à mão mal-assombrada do Deus (PSGH, 18)}

Ainda, há a possibilidade de utilizar a mesma palavra com sentidos diferentes. Mais uma vez, relativizam-se os sentidos das palavras. Palavras ligadas à tradição religiosa cristã são utilizadas tanto no sentido cristão quanto em outro, um que aponte para o neutro indiferenciado. "Deus" é o exemplo paradigmático da utilização do procedimento. Ainda presa a uma moral cristã, G.H. apela para um deus humanizado.

Santa Maria, mãe de Deus, ofereço-vos a minha vida em troca de não ser verdade aquele momento de ontem. (PSGH, 76)

$\mathrm{O}$ apelo, feito diversas vezes ao longo de PSGH, parece um tanto com uma repetição de palavras esvaziadas. Esvaziando-se a palavra, aponta-se para o que é amoral. "Mas é a mais primeira alegria. E só esta, enfim, enfim! é o pólo oposto ao pólo do sentimento-humano-cristão. Pelo pólo da mais primeira alegria demoníaca, eu percebia longinquamente e pela primeira vez - que havia realmente um pólo oposto." (PSGH, 103). Em outros momentos, deus aparece como a matéria não significada do mundo:

Mas eu quero muito mais que isto: quero encontrar a redenção no hoje, no já, na realidade que está sendo, e não na promessa, quero encontrar a alegria neste instante - quero o Deus naquilo que sai do ventre da barata - mesmo que isto, em meus antigos termos humanos, signifique o pior, em termos humanos, o infernal. (PSGH, 83 - 84)

Entre os diversos outros exemplos, a palavra "amor" é utilizada no sentido humanizado, da relação positiva entre duas pessoas, "Assim como também aos homens eu não os havia feito meus, e podia então admirá-los e sinceramente amá-los, como se ama sem egoísmos, como se ama a uma idéia. Não sendo meus, eu nunca os torturava" (PSGH, 
30-31), e num sentido neutro, como na tendência de a matéria (o mundo) se organizar de certos modos e não de outros, "Mas que abismo entre a palavra e o que ela tentava, que abismo entre a palavra amor e o amor que não tem sequer sentido humano - porque porque amor é a matéria viva. Amor é a matéria viva?" (PSGH, 67), algo como o pulsar do mundo silencioso e indiferente ao homem.

Outro procedimento bastante utilizado são as diversas e características manifestações dos encadeamentos dos blocos de texto. Como já foi comentado, a repetição da última frase de um capítulo na primeira frase do seguinte cria a imagem de uma corrente em que os elos se tocam em um único ponto. Os diversos elos se ajustam e formam um conjunto, mas o conjunto não é uma ordem rígida em que um elo determina o elo seguinte. Ao contrário, cada elo guarda boa independência em relação aos demais. Isso reforça a idéia da organização ritual, em que as ações se sucedem sem que sigam uma regra generalizável (como na ciência), obedecendo apenas a uma finalidade específica.

Por outro lado, como o livro se constrói por uma seqüência de afirmações em seguida negadas, os fragmentos razoavelmente independentes cobrem um campo grande de possibilidades de afirmação, que são negadas, apontando para uma tendência de negar qualquer afirmação, e para o epílogo, que é a aceitação de que não se tem mesmo acesso ao mistério, de que haverá um não depois de qualquer sim. Desse modo, apesar de os elos variarem no conteúdo, afirmá-los e negá-los é uma constante e formaliza um modelo de condição humana.

Paralela à imagem da corrente formada pelos capítulos, é a imagem também já citada dos traços que são o tremor do traço anterior. Assim como os elos, os traços têm um ponto comum com seu precedente mas não são determinados por eles. $\mathrm{O}$ traço seguinte é resultado de uma anomalia, uma força não controlada - o tremor. Essa imagem pode ser comparada às determinações das ações humanas por suas porções não controladas, como suas paixões, de modo que as ações humanas sejam pouco determinadas por arbítrio próprio, mas por ser o homem seduzido por algum fator que não é sua consciência. $\mathrm{Na}$ raiz etimológica da palavra seduzir (do latim, $s e(d)$-ducere, conduzir à parte, tirar do caminho) está também a reprodução desse procedimento que figura as impossibilidades humanas diante de um mundo misterioso (restrito acesso à cognição) e sedutor (que apela à nãorazão do homem). 
Configura-se assim um quadro de sins e nãos, de paradas e desvios, que dão ritmo ao enunciado.

Em seu ensaio "O ritmo"60, Octavio Paz defende a idéia de que o ritmo (o tempo) não é medida do mundo, não é um modo de recortar o mundo dando a ele significado, mas é uma instância anterior às medidas, a qual ele chama de "visão de mundo".

O ritmo não é medida - é visão do mundo. Calendários, moral, política, técnica, artes filosofia, tudo enfim o que chamamos de cultura tem raízes no ritmo. ${ }^{61}$

Os sucessivos afirmar e negar dão a PSGH um ritmo bastante característico. Como numa música, o ritmo volta a seu início sucessivas vezes. Mas a cada volta, é outro. É ao mesmo tempo a repetição de uma condição e uma sucessão que não se repete.

[...] o tempo é um permanente transcender. Sua essência é o mais e a negação desse mais. O tempo afirma o sentido de modo paradoxal: possui um sentido - o de ir mais além, sempre fora de si - que não cessa de negar a si mesmo como sentido. Destrói-se, ao destruir-se, se repete; cada repetição é, porém, uma mudança. Sempre o mesmo e a negação do mesmo [...] Quando o ritmo se desdobra diante de nós, algo passa como ele: nós. ${ }^{62}$

Mendilow se refere também ao ritmo e as formas no romance moderno:

Em muitos romances modernos, o ritmo superou o enredo; ou, para usar a nova terminologia, formações substituíram a forma. ${ }^{63}$

Em PSGH, este ritmo (afirmar e negar), expresso em cada fragmento e em cada elemento do livro, faz com que cada compasso binário seja a imagem da condição de G.H. no mundo. Governada por dois potenciais, G.H. (1) busca estabelecer as bases para poder

${ }^{60}$ PAz, O. "O Ritmo" In: O Arco e a lira. Rio de Janeiro: Nova Fronteira, 1982.

${ }^{61}$ Ibidem, p.71.

${ }_{62}^{62}$ Ibidem, p 69.

${ }^{63}$ Mendilow, A.A. O Tempo e o Romance. São Paulo, Cultrix/EDUSP, 1974, p.55. 
caminhar e alcançar finalidades (muitas vezes misteriosas) ao mesmo tempo que (2) destrói as construções por não encontrar fundamento explícito transcendente que sustente a caminhada.

O acoplamento dos módulos do ritmo formulam, no entanto, algo fixo, a afirmação de sins e nãos como visão de mundo. A condição humana é construir e destruir, nem apenas um nem apenas outro.

E é inútil procurar encurtar o caminho e querer começar já sabendo que a voz diz pouco, já começando por ser despessoal. Pois existe a trajetória, e a trajetória não é apenas um modo de ir. A trajetória somos nós mesmos. Em matéria de viver nunca se pode chegar antes. A via-crúcis não é um descaminho, é a passagem única, não se chega senão através dela e com ela. A insistência é o nosso esforço, a desistência é o prêmio. A este só se chega quando se experimentou o poder de construir, e, apesar do gosto de poder, prefere-se a desistência. A desistência tem que ser uma escolha. Desistir é a escolha mais sagrada de uma vida. Desistir é o verdadeiro instante humano. E só esta é a glória própria de minha condição. (PSGH, 176)

Não se trata de um aceitar que se prolongue indefinidamente num ohm mântrico nem uma negação que paralisa incontestável. O módulo rítmico se repete numa visão cíclica da condição humana e se renova sem que uma ordem transcendente, além do ritmo, determine o próximo compasso. A sucessão, em si, é que determina o ritmo fixo que parece transcender e apontar para um lugar que é renovação embora seja repetição.

O ritmo binário é a condição que limita o homem mas não limita os modos que poderão preencher os compassos de sins e nãos.

É a armação trágica que transforma o ser humano em um pequeno mecanismo participante de uma máquina cujas leis não conhece. O homem cumpre o destino de oscilar, independentemente de aceitar ou não sua condição. Ora crê e se liga à vida, ora não crê e é negativo em relação a ela. Aceitar ou não tal condição não o livra do destino. No máximo ameniza as angústias intrínsecas às passagens mais difíceis. Talvez nem isso, 
talvez a sensação de liberdade e de amenização de angústias seja parte do cumprimento do destino. A outra parte seria a angústia evidente. ${ }^{64}$

Joguete das leis do mundo, o homem poderia até ter alguma liberdade no preenchimento dos sins e nãos, o que faria pouca diferença já que seus estados mais íntimos - sensação de estar vinculado ou desvinculado ao mundo - seriam dados por determinações exteriores.

Há momentos, em PSGH, de apego (positividades) à vida. Ainda que reticentes, tais momentos revelam uma vontade de vida que ameaça negar o determinismo do destino, principalmente pela localização, no livro, de dois desses momentos positivos. Logo na introdução, como avaliação global do percurso de G.H., C.L. refere-se a tal percurso como "alegria difícil". Completa: "mas chama-se alegria". Um tanto arbitrário se comparado ao tom determinista do texto (acompanhado do mistério constituinte da relação entre homem e mundo), o comentário sugere ao leitor que ele procure a tal alegria no texto, ainda que alerte para a dificuldade da tarefa.

Do mesmo modo, no fim do texto, depois de descartar todas as possibilidades humanas, atribui a uma certa aceitação a saída para a manutenção do vínculo (menos tenso) com a vida. Por ser o momento final do livro, a afirmação funciona também como conclusão lógica do percurso, como se tudo o que antes foi afirmado não tivesse sido também negado.

Outra passagem que destoa do ritmo determinístico do texto é a que atribui alguma evolução ao homem, aprendizagem, não apenas mudança sem valoração.

Ele, o homem do futuro, nos afagaria, remotamente nos compreendendo, como eu remotamente ia depois me entender, sob a memória da memória da memória já perdida de um tempo de dor, mas sabendo que nosso tempo de dor ia passar assim como a criança não é uma criança estática, é um ser crescente. (PSGH, 110)

\footnotetext{
${ }^{64}$ É verdade que, por não conhecer as leis que regem seu destino, o homem pode até mesmo ter grandes possibilidades de liberdade. No entanto é a sensação de liberdade ou não que ele experimenta, e não a possível liberdade potencial, que rege seus humores. Se se acompanha o caminhar das reflexões de G.H., pode-se supor que suas sensações de potência oscilam sem permanecer prioritariamente num dos dois pólos: liberdade ou claustro. A sensação de liberdade permite que a personagem construa seu relato. Simultânea, ou não, a sensação de claustro permeia o texto de dúvidas e impasses.
} 
Com a exceção dessas significativas, embora raras, passagens (e talvez mais uma ou outra passagem ainda mais reticente), a condição humana se impõe como destino inalienável. As determinações materiais e culturais se impõem ao homem (consciente) como se impõem à barata (supostamente inconsciente). As afirmações de alguma alegria, alguma liberdade e alguma evolução, dadas nas passagens acima citadas, fazem com que o livro seja diferente de uma aporia absoluta. Mas apenas um pouco, de maneira reticente e apoiado, como tudo, em nada.

Na entrevista concedida a Julio Lerner (TV Cultura, 1977), Clarice parece reforçar a visão trágica da vida e a oscilação do homem entre afirmá-la (a vida) e negá-la. Perguntada como ela se sentia, então, durante o período em que não escrevia, Clarice responde "Vamos ver se eu renasço de novo. Por enquanto eu estou morta". Escrever (modo específico de utilizar a linguagem) torna-se então a maneira como ela cumpria seu destino humano, como ela se ligou ao plano secreto do mundo e da vida.

Neste último ano de vida, Clarice repetiu publicamente a vontade de não ser vista como escritora, mas como pessoa, de acordo com a idéia de que escrever não era profíssão escolhida mas modo de ser especificamente humana e cumprir um destino. Diferente dos escaravelhos, o ser humano "perdeu" sua máscara natural.

- Eu sei: nós dois sempre tivemos medo de minha solenidade e da tua solenidade. Pensávamos que era uma solenidade de forma. E nós sempre disfarçávamos o que sabíamos: que viver é sempre questão de vida e de morte, daí a solenidade. Sabíamos também, embora sem o dom da graça de sabê-lo, que somos a vida que está em nós, e que nós nos servimos. $\mathrm{O}$ único destino com que nascemos é o do ritual. Eu chamava "máscara" de mentira, e não era: era a essencial máscara da solenidade. Teríamos de pôr máscaras de ritual para nos amarmos. Os escaravelhos já nascem com a máscara que se cumprirão. Pelo pecado original, nós perdemos nossa máscara. (PSGH, 116)

A linguagem (escrever) funciona para G.H., o ser humano retratado por Clarice Lispector em A Paixão segundo G.H., como maneira de cumprir seu destino, sem ter consciência das causas últimas de suas ações. É a máscara humana, organizadora de 
modelos e rituais, a serviço de um plano não conhecido, ou de suas próprias escolhas. Não se sabe.

A linguagem é o suporte do ritual com o qual o ser humano cumpre de maneira precária (pois sequer sabe que (como) cumpre) e precisa (pois cumpre) seu destino fatal. 


\section{CAPÍTULO III \\ PÁTHOS E LIBERDADE}

Tenho várias caras. Uma é quase bonita, outra é quase

feia. Sou um o quê? Um quase tudo.

- C.L. -

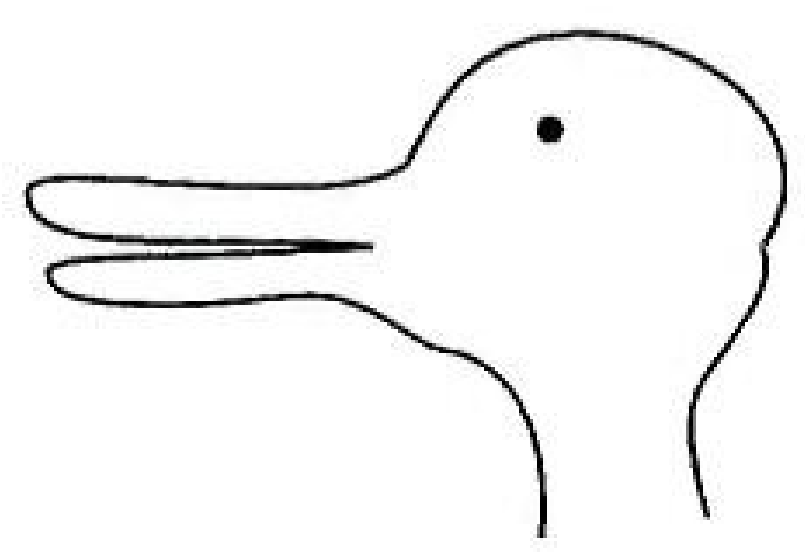

fig. 1 - cabeça L-P (Wittgenstein, Jastrow)

Há uma figura ali em cima. Este texto tem determinadas características que fazem com que quem o leia espere que a figura acima, ou qualquer outra porção de tinta no papel, tenha um significado, uma função ou uma intenção. Entender o que a figura significa ou representa passa em algum momento por uma tentativa de re-conhecimento. Se a figura é apresentada como a cabeça de um pato, ainda que não o enxerguemos logo, procuramos um bico, um olho etc. Reconhecê-lo é distinguir características que o enquadrem na categoria "pato". A partir do instante do reconhecimento, a figura ganha afinidade com outros patos. Ainda, em algum grau, outras características de outros patos, que não estão na figura, são a ela vinculadas. Ao mesmo tempo, sabendo-se que a figura é um pato (e de algum modo já é um pato no seu modo de ser apreendido e tratado por aquele que o reconhece), a figura não pode ser um cavalo, uma galinha, um carro ou um martelo.

Se, por outro lado, a figura é apresentada como a cabeça de uma lebre, procuramos então na figura as orelhas, a boca, o olho, e ela deixa de ser um pato. A figura agora é uma 
lebre, não é um cavalo, não é uma casa, não é um pato. Essa é parte da discussão que Wittgenstein $^{65}$ faz da figura de Jastrow em suas Investigações Filosóficas.

É curioso que a partir do momento em que reconhecemos uma cabeça de lebre, perdemos a cabeça de pato, e vice-versa. Temos dificuldade de tratar objetos que não correspondem a modelos anteriormente construídos, que não podem ser bem aparentados com outros objetos. A cabeça L-P, a partir do momento em que entendemos a representação simultânea do pato e da lebre, passa a ser um objeto singular e confuso. Para ser apresentada, é preciso passar pela referência a objetos conhecidos (pato e lebre) para apenas depois negá-los. Não é um pato, não é uma lebre, é uma cabeça L-P. Porém, depois da exposição, torna-se difícil apagar o percurso que foi feito durante a apresentação do novo objeto. A figura fica sendo uma não-lebre, um não-pato, em vez de ser apenas o objeto esquisito cabeça L-P.

A complexidade da definição do objeto faz com que sua apresentação e seu reconhecimento sejam extensos, diferente do que acontece com a apreensão da contingência que apenas é - o objeto se relacionar por vias lógicas com uma série de outras coisas e transcende o "instante-já".

Ainda, no processo de negação do percurso da definição para tentar ficar apenas com a experiência de ver uma cabeça L-P, resta muita sujeira (traços, às vezes irreconhecíveis, do percurso). É preciso, então, negar também esta sujeira. Mais à frente, apagar também todas as negações para que a cabeça L-P surja sozinha, instantânea, o que não parece tarefa das mais fáceis para seres dotados de memória. Desde o instante seguinte ao exato e ínfimo momento de sua aparição frente a uma consciência, a cabeça não é nem apenas uma forma sem conteúdo, nem experiência pura. Quando começam a surgir questões como "o que é isso?", "que é que o autor quis dizer com isso?" etc, ela já se estabeleceu em um conceito, que vai ganhando forma e agregando significado (transcendendo o intante-já), enquanto a consciência a tem sob sua atenção.

Isso faz com que, no caso de Clarice Lispector em PSGH, o texto trafegue pela negação insistente de tudo o que ele mesmo diz (pato: não é um pato, lebre: não é uma lebre) e parece, muitas vezes, não sair do lugar - uma espécie de retrato de um impasse hiperbólico alimentado por si mesmo. O sucesso da tarefa de construir (um texto) desconstruindo torna-se ainda mais improvável, pela óptica da razão, quando é adicionada

\footnotetext{
${ }^{65}$ Wittgenstein, L. Investigações Filosóficas. São Paulo: Abril Cultural, 1984.
} 
a tudo a tendência humana de completar (classificar, sistematizar, generalizar) o que se diz e compará-lo a modelos prévios, mesmo no caso de um borrão; ou então descartar a mancha, em vez de tomá-la como mancha e assim, disforme mesmo, apreendê-la, por exemplo categorizando-a como 'mancha' ou como 'disforme'. É comum que se tome o tremor como traço, assim como um ponto de tinta torna-se um olho quando se conhece modelos para cabeças de lebres e de patos.

Wittgenstein apresenta uma segunda figura para falar desta tendência humana a completar.

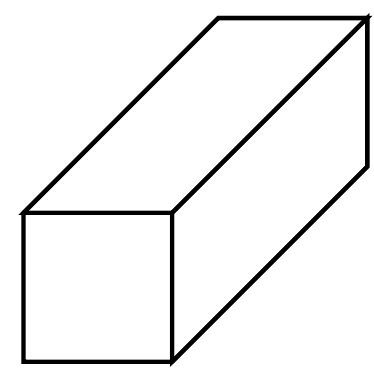

fig. 2 - (Wittgenstein)

Quando se olha esta figura, é comum que os nove segmentos de reta tornem-se a representação de um prisma tridimensional, com volume. Ainda mais, o prisma pode ser um degrau, parte de uma escada. É difícil, para um homem do século XX, não assumir as convenções da perspectiva em desenho e fazer da figura bidimensional um volume, talvez até a representação parcial uma escada ou algo parecido. Supõem-se as entrelinhas. No caso de Clarice Lispector, mesmo que a entrelinha já esteja fisgada, ainda há de se descartar as linhas. Uma diferença, porém, é que a entrelinha não costuma ser as costas de um degrau associado a seu volume, mas um não-volume ou uma não-forma. $\mathrm{O}$ avesso da forma, enquanto forma, não serviria. O que se busca, ainda que pela forma, é o avesso da idéia de forma.

Ainda, dependendo da legenda que se dê à figura, pode-se induzir o modo como ela é recebida. Se se trata de um degrau, imagina-se logo uma escada; se se trata de uma caixa de vidro, o interior da caixa passa a ser relevante; se são segmentos de reta num plano bidimensional, o que poderia ser um retângulo em perspectiva, na parte lateral da caixa, passa a ser um losango. Fica difícil etiquetar a figura sem tirar dela possibilidades de 
significação e sem guiar a complementação da figura por continuidade física (parte da escada) ou de significação (uma caixa pode conter coisas) .

João Adolfo Hansen, em seu ensaio sobre A Hora da estrela ${ }^{66}$, aponta para o procedimento de um enunciado segundo o qual diluem-se as formas para construir (destruir) o texto, como modo de afirmação da impossibilidade de um narrador intelectualizado (um escritor) pensar o excluído (não se trata de pensar sobre ele). $\mathrm{O}$ fracasso tematizado ganha força de sucesso quando é sucesso de figuração do fracasso, embora seja desfiguração enquanto procedimento. Em A Hora da estrela, a impossibilidade do discurso pode ser lida como resultado da separação social, de classe, entre Rodrigo S.M. (narrador) e Macabéa (narrado), "Macabéa é de outra classe, ela que é uma desclassificada"67. O discurso de uma das classes não serve à apreensão da outra. Macabéa escorre líquida sem poder ser concretizada em forma. Em PSGH, semelhante, a separação inconciliável se dá entre sujeito narrador e objeto narrado que, paradoxo, são a mesma pessoa, eu distinto de si mesmo. O tempo que separa a experiência com a barata, imanente, e o tempo da narrativa, sempre transcendente pela necessidade de permanência da palavra, é o que faz fracassar a tentativa de G.H-eu-narradora pensar e dizer a G.Houtro-objeto. "O narrador se narra dissolvendo-se [...] para impedir que uma fala plena de natureza reproduza o padrão institucional dos materiais - discursos - das transformações de seu Autor"68, evidencia "a convenção da competência letrada enquanto evidencia a incompetência de sua convenção"69.

"Você sabe se a gente pode comprar um buraco?"70, diz Macabéa pela construção de Rodrigo S.M., na verdade Clarice Lispector, e põe em relevo, pelo non-sense da pergunta, a incompatibilidade dos valores entre narrador e narrado. Neste caso, trata-se do conhecimento sobre o "valor" em dinheiro das coisas, base da diferenciação entre as classes sociais, sobre o qual Rodrigo S.M. tem domínio e Macabéa não. Para G.H., a incompatibilidade se dá entre a narradora submetida a valores e a suposta instância neutra, experiência pura, alheia a classificações e julgamentos.

\footnotetext{
${ }^{66}$ Hansen, J.A. "Uma estrela de mil pontas" In: Lingua e Literatura, São Paulo, (17), 1989, pp.107-122.

${ }^{67}$ Ibidem, p. 110.

${ }^{68}$ Ibidem, p. 109.

${ }^{69}$ Ibidem, p. 112.

${ }^{70}$ Lispector, C. A Hora da estrela. Rio de Janeiro:Rocco, 1998, p.49.
} 
O cinema, ao longo de seus pouco mais de cem anos de existência, foi criando seus artifícios (ferramentas/códigos) para produzir ilusões e contar histórias. Um sonho, por exemplo, pode ser retratado por uma imagem embaçada, por tons diferentes das cores ou por um aviso, anterior ou posterior, de alguém adormecendo ou acordando. No entanto, graças ao treinamento do espectador, é possível hoje retratar um sonho sem aviso tão explícito. Ao entrar numa sala de cinema, uma pessoa já habituada com determinados padrões de ilusão não se assusta mais com alguns dos antes assustadores filmes dos anos vinte ou trinta. Pode até rir de alguma obviedade na construção da ilusão, riso que pode ser interpretado como distanciamento, ao contrário do envolvimento sinalizado por algum susto.

Se os autores de filmes quisessem que soubéssemos imediatamente que a cena se passa na mente, poderiam até usar um artifício mecânico, fazer a figura oscilar, ou se dissolver gradualmente, ou se enevoar até desaparecer. Esse recurso formal, embora possa parecer ingênuo ou elementar, era suficiente para esclarecer, a certas platéias, que estava acontecendo uma rápida fuga da realidade ${ }^{71}$

Para retratar a novidade (o susto) e evitar o afastamento que o reconhecimento e a racionalização determinam, é preciso negar a fórmula apre(e)ndida de antemão pelo espectador. Ainda, pela supressão da representação dos limites bem determinados entre sono e vigília, pode-se buscar a produção de um efeito improvável quando as fronteiras formais são mais rígidas. Não se trata apenas de retratar um sonho de uma maneira nova - a novidade vale pelo que carrega de imprevisto, surpreendente e mal formado (não reconhecido, difícil de classificar). A partir do momento em que a experiência se endurece numa forma específica aceita, o novo já foi perdido. O excesso de forma (palavra ou o que quer que seja) faz perder o silêncio e o escuro dos interstícios. "Num famoso comentário,

\footnotetext{
${ }^{71}$ CARRIËRE, J.C. A Linguagem secreta do cinema. Rio de Janeiro: Nova Fronteira, 1995, p.17.

Essa rápida passagem sobre o cinema ilustra um princípio de gramática sobre o qual autores e espectadores estão de acordo de modo a que uma idéia anterior (a fronteira entre vigília e sonho) seja retratada. Não se trata de um conhecimento universalmente compartilhado, mas um código criado, ensinado e aprendido. Um exemplo interessante, no mesmo livro, dá conta de sessões de cinema na África do começo do século, em que os espectadores reconheciam pessoas, objetos, movimentos, mas não conseguiam montar enredos minimamente complexos nem reconhecer ligações simples entre uma cena e outra separadas por um corte de câmara. Para tornar os filmes mais (ou menos) interessantes, adicionou-se, ao lado da tela, um funcionário que era encarregado de explicar as cenas à audiência. (p.13)
} 
Sacha Guitry disse uma vez: 'O concerto que vocês ouviram é de Wolfgang Amadeus Mozart. E o silêncio que veio depois também é de Mozart.' [...] Vários músicos contemporâneos dizem que seu objetivo principal é deslocar-se de um silêncio a outro."72

Quando entra na sala de cinema, o espectador se insere em determinado sistema de idéias relacionado ao que é, para ele, cinema. Do mesmo modo, ao encontrar uma mancha emoldurada, tenta responder a suas perguntas sobre ela ("o que é isso?", por exemplo) de acordo com seu conhecimento sobre artes plásticas. Antes de se dar por satisfeito, irá procurar olhos, bicos, orelhas, frutas, animais, letras, entre outras possibilidades de decodificação e interpretação, para talvez dizer que é uma "obra abstrata", expressão com a qual emoldura o que não consegue apreender em outras categorias. Esse modo de contextualizar salva pela segurança da forma, ainda que transforme, às vezes, um susto numa caixa enorme que o contenha. $\mathrm{O}$ que se vê é uma caixa. O susto fica bem escondido lá dentro.

O visível nos tranqüiliza. Tudo o que podemos dar forma nos tranqüiliza. Mesmo que esta forma seja extravagante, ainda assim ela vem de nossas mãos, nós a modelamos. O que perturba não tem forma definida, que se possa reproduzir, por mais inteligente que seja a tentativa; e ainda assim o sentimos respirar e se mover, chutando-nos e às vezes nos mordendo. ${ }^{73}$

A própria Clarice, numa crônica de jornal chamada "Abstrato é o figurativo", diz: "Tanto em pintura como em música e literatura, tantas vezes o que chamam de abstrato me parece apenas o figurativo de uma realidade mais delicada e mais difícil, menos visível a olho nu." 74 , o que se liga à idéia de uma nomenclatura grosseira que não adere à sutileza da realidade. Nesse caso, a realidade é a própria arte e a palavra grosseira e redutora é a etiqueta "arte abstrata".

A capa de um romance, bem como tudo o que ademais funciona como suporte (papel, tamanho, numeração de páginas), faz com que o leitor chegue à primeira linha de texto já munido de uma porção de ferramentas próprias para decodificar e interpretar

\footnotetext{
${ }^{72}$ Ibidem, p.33.

${ }^{73}$ Ibidem, p. 97.

${ }^{74}$ Lispector, C. A Descoberta do mundo. Rio de Janeiro: Rocco, 1999, p.316.
} 
romances. Clarice Lispector compartilha com vários de seus contemporâneos a proposta de questionar tais ferramentas e formalizações cristalizadas ${ }^{75}$. Como vários outros, apóia-se em um estilo (particular) que contrapõe a autora aos outros autores e à tradição. Assim como Guimarães Rosa (para citar apenas um contemporâneo brasileiro), tem suas obras reconhecidas pelo modo de construir um texto, ao ponto de o adjetivo clariceano poder ser cunhado (semelhante a rosiano). No entanto, em PSGH e em alguns outros textos seus, Clarice radicaliza na busca pela paradoxal forma não formalizada, de uma maneira que o romance passa a se afirmar mais pela negação que pela afirmação de suas possibilidades. G.H., narradora, desconfia daquilo que acabou de inventar como descrição do que viveu. A novidade não permanece como tal por mais de algumas poucas linhas. Diferente de outros autores que, apesar de desconfiados, apóiam no vazio suas construções (seus textos) e do vazio se esquecem, a Clarice Lispector de PSGH não se afasta demais do vazio nunca. ${ }^{76}$

O jogo de linguagem [...] segue, precisamente, em Clarice Lispector, uma direção oposta ao de Guimarães Rosa. Guimarães Rosa, ao contrário de Clarice Lispector, apresenta um etilo do acréscimo [...] alcança transcendência através da afirmação do mundo.

\footnotetext{
${ }^{75}$ Como já foi esboçado no capítulo I, quando da referência ao ensaio de Julio Cortázar sobre o romance contemporâneo.

Cortázar, J. Obra Crítica (v. 1). Rio de Janeiro: Civilização Brasileira, 1998.

${ }^{76}$ Relativo a essa insistência pela dissolução, o (bem-humorado) poema de João Cabral de Mello Neto:
}

\section{CONTAM DE CLARICE LISPECTOR}

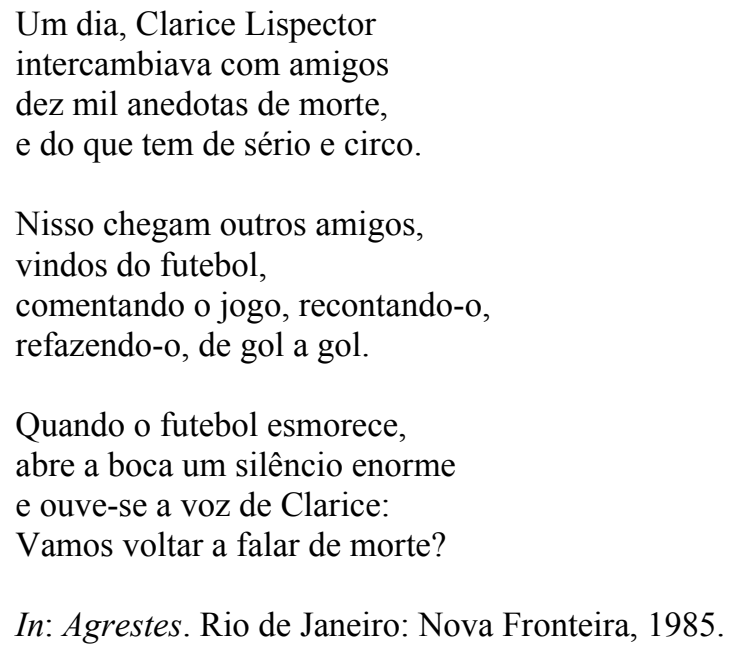


Em Clarice Lispector [...] uma espécie de mergulho nas potências obscuras da vida, através da negação do mundo, das relações humanas, da ética. Na sua visão de realidade, o Ser e o Nada se identificam. ${ }^{77}$

O discurso se debate perto do nada, tematizando-o, antes de tematizar qualquer coisa. Há uma necessidade sistemática de não se identificar com construção alguma, não insistir em caminho nenhum sem logo voltar ao descaminho. Essa necessidade programática de não se identificar com qualquer formalização ${ }^{78}$ faz com que todo o discurso esteja sempre pronto para ir a qualquer lugar, embora não vá nunca (em certo ponto de vista) a lugar nenhum - uma tentativa de mimetizar o silêncio pela palavra ${ }^{79}$.

A moldura do quadro e a capa do livro, além de anunciarem um tipo de experiência, sugerem um conjunto de valores e significados. Isto insere a pintura e o romance, para o espectador, na ordem de coisas que são produto da vontade humana, de suas escolhas conscientes; ou, pelo menos, o romance, como obra humana, insere-se no rol das tentativas humanas de atingir finalidades. Roquetin, narrador de $A$ Náusea, questiona alguns valores intrínsecos de um romance que diferem, no fundamento, da experiência.

Mas é preciso escolher: viver ou narrar. [...]

Quando se vive, nada acontece. Os cenários mudam, as pessoas entram e saem, eis tudo. Nunca há começos. Os dias se sucedem aos dias, sem rima, nem solução: é uma soma monótona e interminável. De quando em quando se procede a um total parcial, dizendo: faz três anos que viajo, três anos que estou em Bouville. Também não há fim: nunca deixamos uma mulher, um amigo, uma cidade, de uma só vez.

\footnotetext{
${ }^{77}$ Nunes, Benedito. O Mundo Imaginário de Clarice Lispector.In: O Dorso do Tigre. São Paulo: Perspectiva, 1969, pp.138-189.

${ }^{78}$ Como já foi dito várias vezes neste trabalho, a dissolução das formas deve ser relativizada na medida em que um (não-)romance de cento e oitenta páginas foi construído e não desaparece dissolvido no ar.

${ }^{79}$ Num depoimento dado na Festa Literária de Paraty (FLIP) de 2005, Marina Colasanti, amiga próxima de Clarice Lispector, comentava sobre o hábito que Clarice tinha de mentir (é bastante conhecida a confusão sobre sua idade produzida por ela mesma). Sempre que chegava à casa de Clarice, notava a grande quantidade de livros soltos por todos os lados. Se perguntada, no entanto, o que estava lendo, Clarice normalmente respondia que não estava lendo nada, que lia muito pouco. Para Marina Colasanti, essa era mais uma das mentiras de Clarice que não entendia. Passados uns anos, e incomodada com a história, chegou à conclusão de que Clarice tinha necessidade de não se identificar com nada. Se dissesse que lia Dostoievski, as outras pessoas a olhariam com essa informação em vez de olharem-na desarmados.

Esta pequena narração se alinha bastante bem com a idéia de que os narradores de Clarice Lispector, G.H. em particular, estão num lugar de fala sempre próximo do vazio de não-identificação, de nãosignificação, de não-palavra, de não-subjetivação - um esforço grande para dizer sem dizer, ou para não-dizer dizendo.
} 
[...] Viver é isso. Mas quando se narra a vida, tudo muda; simplesmente é uma mudança que ninguém nota: a prova é que se fala de histórias verdadeiras. Como se pudesse haver histórias verdadeiras; os acontecimentos ocorrem num sentido e nós os narramos em sentido inverso. Parecemos começar do início: "Era numa bela noite de outono de 1922. Eu era escrevente em Marommes." E na verdade foi pelo fim que começamos. Ele está ali, invisível e presente, é ele que confere a essas poucas palavras a pompa e o valor de um começo. "Estava passeando, saíra do vilarejo sem perceber, pensava em meus problemas de dinheiro." Essas frases, tomadas simplesmente pelo que são, significam que o sujeito estava absorto, deprimido, a cem léguas de uma aventura, exatamente nesse tipo de estado de espírito em que se deixam passar os acontecimentos sem vê-los. Mas o fim, que transforma tudo, já está presente. Para nós o sujeito já é o herói da história. Sua depressão, seus problemas de dinheiro são bem mais preciosos do que os nossos, doura-os a luz das paixões futuras.

[...] Esquecemos que o futuro ainda não estava ali; o sujeito passeava numa noite sem presságios, que lhe proporcionava de cambulhada suas riquezas monótonas, ele não escolhia.

Quis que os momentos de minha vida tivessem uma seqüência e uma ordem como os de uma vida que recordamos. O mesmo, ou quase, que tentar capturar o tempo. ${ }^{80}$

Não importa se expressão da escolha do indivíduo, ou se expressão, pelo indivíduo, de uma ideologia compartilhada e historicamente determinada, a simples mediação da palavra torna já estranha a tentativa de escrever com isenção de finalidade, na medida em que a palavra carrega nela moldes (molduras) e finalidades (muitas vezes irreconhecíveis) da ideologia a ela associada.

O romance é obra humana organizada e pressupõe usualmente determinadas relações causais. O discurso é organizado segundo finalidades, tanto (1) o final do livro quanto (2) alguma intenção do autor. Não se trata da sucessão de momentos presentes sem necessidade de encadeamento lógico. A utilização de uma linguagem, pelo autor, compartilhada em grande parte com o leitor, faz com que os pressupostos lógicos dessa

$\overline{{ }^{80} \text { SARTRE, J.P. A Náusea. Rio de Janeiro: Record, 1997, pp. 66-67. (grifos meus) }}$ 
linguagem estejam mais presentes o tempo todo na fruição do livro. Na experiência cotidiana ordinária, os pressupostos lógicos estão presentes no sujeito e correspondem aos acontecimentos do mundo. Por isso, a linguagem serve como ferramenta adequada ao mundo cotidiano. É a náusea, experiência não ordinária, que questiona tais pressupostos lógicos e, por conseqüência, a própria linguagem. Isenção de finalidade significaria a suspensão do tempo, o presente sem conseqüência futura (sem a tentativa humana de generalizar a seqüência local para formular uma lei de causalidade recorrente) e sem historicidade. A palavra é tão precária quanto o ato criminoso que, para negar uma moral, inverte uma regra. $\mathrm{Na}$ medida em que o sistema pode ter sanções para as inversões, que fazem também parte do sistema, inverter uma regra nunca nega o sistema sem que o afirme ao avesso.

Martim, em $A$ Maçã no escuro, é herói icônico dessa tentativa de inversão da moral. Martim comete um crime (que ao fim revela-se fracassado mesmo na sua intenção primeira, anterior aos julgamentos, já que a esposa não havia morrido) como negação inicial de um sistema. A essa tentativa, Benedito Nunes, em O Drama da Linguagem ${ }^{81}$, dá o nome de "saída romântica". Ela se baseia na crença da liberdade e autonomia do homem diante de um sistema de valores. Ao mesmo tempo, inevitável, a primeira negação da moral, pelo imoral, transforma-se em afirmação da transgressão. Pode-se dizer, por outro lado, que o gesto de negação é símbolo da possibilidade de (sempre) negar. Desse modo, o imoral, se não se trata da afirmação de um comportamento transgressor específico, é, no mínimo, a afirmação da possibilidade de negar, o que pode ser parafraseado em afirmação da liberdade de escolha. Gilberto Martins tem opinião semelhante:

No entanto, ocorre que aquele que possui o poder da palavra e o discurso da certeza é dotado também de livre arbítrio e da opção de escolha. Ao contrário do heroísmo da Antigüidade Clássica, em que o destino é mais do que mera contingência, determinando o comportamento do herói, a heroicidade moderna coloca nas mãos do homem a condição de seu próprio destino. [...] Martim opta pelo ato criminoso, assumindo posteriormente as punições decorrentes [...] e o herói confunde-se, agora, com o criminoso. ${ }^{82}$

\footnotetext{
${ }^{81}$ Nunes, B. O Drama da linguagem. São Paulo: Ática, 1989.

${ }^{82}$ Martins, G.F. As Vigas de um heroísmo vago: três estudos sobre A Maçã no escuro". São Paulo: FFLCH/USP, 1997, p.76. (dissertação de mestrado).
} 
Se visto como o comportamento interditado, o mal é justamente a ação que inverte o comportamento recomendado. Independentemente de a manifestação do mal ser produto de uma potência animal humana, de uma escolha livre consciente, de forças sociais ou se é resultado de uma interação entre as três possibilidades anteriores, a sociedade elege determinados comportamentos como aceitos e outros como vetados, com a finalidade de manutenção e produção de uma ordem avaliada como positiva. O mal é um conceito compartilhado, do grupo, e, a princípio, para ser identificado, independe de que tipo potencial individual (se consciente ou inconsciente) o tenha gerado. Tal divisão entre certo e errado é determinante não só nas ações sociais do homem como também nos seus processos mentais, seus modos de apreender o mundo e expressar-se em palavras. Livrarse dessa determinação moral imposta é força motriz para vários personagens da autora. $\mathrm{O}$ mal, como primeira inversão das forças que apontam e recomendam o bem, é a tentativa romântica em busca de liberdade, e pode ser identificado, como primeiro exemplo, com o crime de Martim.

O mal, em outros textos, como "O búfalo"83, assume outra faceta, além daquela da proibição social: a do potencial agressivo animal vetado socialmente. A prisão da personagem do conto a um sistema de valores veta seu encontro com partes de si mesma, a ponto de ela promover uma busca organizada do mal no jardim zoológico. O mal neste caso não é a ação maldosa, mas uma potência geradora de maldade. A busca se coloca, então, em relação ao mesmo sistema que veta o crime (como o de Martim), não pela execução (imoral mas não amoral) do ato mas pela busca de uma energia escondida pelo código moral, no homem, ainda no estado de potência, e não avaliada em bem ou mal (o búfalo escaparia de internalizar o código moral). Antes do encontro, o ódio - o mal, neste conto -, ficava transfigurado

Imaginar que talvez nunca experimentasse o ódio de que sempre fora feito o seu perdão. ${ }^{84}$

, e mesmo no acesso ao primitivo, são reconhecidas ainda manifestações do ódio que encobriam o ódio potencial

\footnotetext{
${ }^{83}$ Lispector, C. "O Búfalo" In: Laços de Família. Rio de Janeiro: Rocco, 1999.

${ }^{84}$ Ibidem
} 
Então, nascida do ventre, de novo subiu, implorante, em onda vagarosa, a vontade de matar - seus olhos molharam-se gratos e negros numa quase felicidade, não era o ódio ainda, por enquanto apenas a vontade atormentada de ódio como um desejo, a promessa do desabrochamento cruel ${ }^{85}$

até, por fim, surgir "incompreensível e quente, enfim incompreensível", sem que assuma forma de "perdão" ou de "vontade de matar".

Um terceiro exemplo ${ }^{86}$ em que o mal é apresentado, desta vez não como busca do personagem, é "A Legião estrangeira"87. Neste conto, Ofélia - uma criança muito adulta, o que pode ser interpretado como 'devidamente conformada e enrijecida pela moral' - "como uma atuação toda interior, como se para tudo houvesse um tempo, levantava com cuidado a saia de babados, sentava-se, ajeitava os babados [...] Tinha opinião formada a respeito de tudo." ${ }^{88}$, quando colocada em contato com um animal desconhecido, um pinto, tem despertada em si uma agressividade antes desconhecida, que a leva rapidamente a matar o animal. Distante do lugar de muitos dos narradores e protagonistas clariceanos, onde o equilíbrio instável e o inexplicável são o cenário, para Ofélia as coisas tinham sentido exato e se concatenavam de maneira lógica. A causalidade, difícil de ser estabelecida quando traços e tremores se confundem, é óbvia quando apresentada pela moral mais rígida desta criança.

Eu ainda preferia conselho e crítica. Já menos tolerável era seu hábito de usar a palavra portanto com que ligava as frases numa concatenação que não falhava. ${ }^{89}$

Aqui, o mal é uma potência incontida, posta em ação. Não se trata de uma violação consciente (às vezes, planejada) de uma lei, mas da eclosão rápida de uma potência destrutiva. As categorias morais são dissolvidas e a maturidade se esvai.

\footnotetext{
${ }^{85}$ Ibidem

${ }^{86}$ Há dezenas de outros exemplos na obra clariceana. Servimo-nos destes para apresentar nuances do mal que nos ajudam a especificar o procedimento em PSGH.

${ }^{87}$ Lispector, C. "A Legião Estrangeira" In: A Legião Estrangeira. Rio de Janeiro: Rocco, 1999.

${ }^{88}$ Ibidem, p.91.

${ }^{89}$ Ibidem, p.92. (grifos meus)
} 
Diante de meus olhos fascinada, ali diante de mim, como um ectoplasma, ela estava se transformando em criança. ${ }^{90}$

O mal de Ofélia é paralelo à força, neutra em relação à moral, que move G.H. no "assassinato" da barata. Essa força, quando eclode, escapa tanto do controle moral do indivíduo quanto escapa das possibilidades de ser descrita. Em "A Legião estrangeira", o assassinato do pinto ocorre em surdina e, neste caso, distante dos olhos da narradora adulta, índice de que também a lógica e a causalidade fossem obscuras a quem narra.

Não vi quando foi, não vi quando voltou. Em algum momento por acaso e distraída, senti há quanto tempo havia silêncio. ${ }^{91}$

Também em "O Búfalo" o aparecimento do ódio se dá disforme, no animal muito preto do qual a face, de tão escura, não deixava distinguir as formas, "tão preto que à distância a cara não tinha traços." ${ }^{92}$. Diferente do mal de Ofélia, surgido do inesperado e sema visar, o mal para a personagem de "O Búfalo" surge depois de a personagem passar por vários animais do zoológico, numa busca organizada por ela mesma.

Em PSGH, a eclosão do neutro é de difícil descrição mesmo para a narradora que tudo vivenciou. Como descrito no trecho de A náusea antes citado, a vivência e a narrativa são instâncias excludentes. ${ }^{93} \mathrm{Na}$ impossibilidade de envolver com aderência, em palavras, as forças e os fatos presentes no acontecimento produzido pelo descontrole, a fixação em palavras é dada por uma embalagem que sempre sobra e/ou falta em relação ao referente. É como guardar no conceito "arte abstrata" toda aquela expressão artística que comunica e faz referência ao mundo, mas de um modo irreconhecível.

O paralelo entre a experiência de Ofélia e a de G.H. é reforçado também no modo de descrever o indescritível. A mesma "alegria difícil" de G.H. é o que a narradora adulta

\footnotetext{
${ }^{90}$ Ibidem, p. 95.

${ }^{91}$ Ibidem, p.99.

${ }^{92}$ É, aqui, difícil de reconhecer as formas do que não pode ser dito, tanto quanto em relação à empregada Janair, indizível pelo discurso de classe de G.H., cujo rosto a narradora não lembra, ou quanto a Macabéa, cujos traços escapam ao narrador Rodrigo S.M.

${ }^{93}$ Isso está em acordo com Sartre, embora ele não considere o mal inconsciente como uma potência humana mas como uma ação das contingências sobre a consciência (consciência, para ele, é equivalente a ser humano e a liberdade).
} 
supõe ter acontecido com a menina. "Em silêncio eu via a dor de sua alegria difícil."194 / "A mim, por exemplo, a personagem G.H. foi dando pouco a pouco uma alegria difícil; mas chama-se alegria." (PSGH, 7)

Como definiu Pasta Jr. ${ }^{95}$, trata-se da (in)expressão do mistério_- em oposição ao enigma - que deve ser contemplado e não pode ser decifrado ${ }^{96}$. Ligado a este mistério está o contraponto da saída romântica na obra de Clarice Lispector, que é, segundo a terminologia de Benedito Nunes, a saída mística. A primeira saída baseia-se, entre outras forças, na revolta como possibilidade de libertação. Assim, o conflito entre uma ordem e o sujeito revoltado configura-se como ação e depende da opção que o indivíduo tem de se opor às diretrizes de ação do mundo. Do outro lado, a saída mística baseia-se numa transformação interior ao homem de um modo que ele entenda algo sobre as configurações e os movimentos do mundo em relação a ele. Como é uma transformação interior, o entendimento pode passar também por entender-se.

$\mathrm{Na}$ via romântica, entre as premissas do movimento do sujeito estão suas possibilidades de, pela revolta, modificar o mundo exterior. O indivíduo acredita em sua capacidade de escolha e modificação do mundo. Nisso baseia-se sua idéia de liberdade. Em $\mathrm{ME}^{97}$, tal saída torna-se um tanto desconjuntada por dois motivos. Em primeiro lugar, a escolha do sujeito, sua revolta (o crime) é mal sucedida na medida em que a tentativa não se concretiza em assassinato da mulher. Seu controle sobre o mundo é sobreposto pelas circunstâncias que agem além de sua escolha. Em segundo lugar, o sistema de regras por ele violado (em particular, não matar) está de tal modo concretizado nele e no mundo que a sanção ao crime vem (ele é preso) e é aceita por ele como momento final do livro ${ }^{98}$.

${ }_{94}^{94}$ Lispector, C. "A Legião Estrangeira" In: A Legião Estrangeira. Rio de Janeiro: Rocco, 1999, p.95.

${ }^{95}$ PASta JR., J.A. "O Romance de Rosa - temas do Grande sertão e do Brasil". In: Novos Estudos - CEBRAP n.55, nov. 1999 , p.62.

${ }^{96}$ Do mesmo modo, o mal, assim como a loucura, desvios das convenções sobre o comportamento moral e racional, são afastados da sociedade em prisões e manicômios, como modo de separar o descontrolado da sociedade controlada. De algum modo, a arte que é pouco entendida em termos racionais e reconhecíveis, embora seja apreendida e toque o ser humano, ganha denominações do tipo "arte abstrata", assim como as prisões e manicômios retêm o descontrole moral e racional, assim como a palavra (moral e racional) não consegue ser precisa e aderir ao descontrole. Do mesmo modo, no mural misterioso na parede do quarto de Janair, os traços (controle) confundem-se com os tremores (descontrole) para formar figuras humanas, e bem ilustrar a dificuldade de a palavra (traço) apreender sozinha também a experiência humana, por exemplo, de mal e de loucura.

${ }^{97}$ ME - Lispector, C. A Maçã no escuro. Rio de Janeiro: Rocco, 1999.

${ }^{98}$ Em Crime e Castigo, o protagonista Raskolnikov faz uma longa exposição sobre sua tese de dividir os homens em ordinários e extraordinários. Se ele era um extraordinário, e é provável que assim se sentisse, seu crime estaria justificado. Segundo ele, o homem ordinário deve se sujeitar às regras do mundo. Os extraordinários, ao contrário, estariam acima das regras. Teriam, por isso, autorização ética para violá-las. 
Tal aceitação da sanção é já o sinal de um terceiro entrave para a via romântica. Aceitar é reconhecer a potência do mundo e a impotência do sujeito, o que minimiza o sentido da revolta. Aceitar é parte da saída mística, na qual, ao invés de se fazer sujeito, o indivíduo se entende como objeto das ações do mundo. Entender e aceitar relacionam-se, ainda, de um modo negativo: o processo de transformação interior que configura a saída mística, e que é um entendimento do que é o homem, do que é o mundo e de suas relações, é também a aceitação de que o homem não entenderá. Assim, a saída mística pressupõe o mistério e baseia-se na sujeição do indivíduo às forças do mundo.

Por fim, uma das tensões que movem a narrativa em ME, e que não é resolvida, é a tentativa de conciliação entre as vias mística e romântica. Benedito Nunes refere-se a "cair num poço horizontal" para representar os dois eixos distintos e independentes. Algumas premissas de um e de outro eixo são opostas - ação e sujeição, revolta e aceitação, por exemplo - e não coexistem num mesmo momento sem que produzam uma tensão, não entre posições diferentes do mesmo eixo, mas entre eixos diferentes. $\mathrm{O}$ que pode acontecer é a sucessão de momentos de alívios parciais de tensão - ora pela via romântica, ora pela via mística -, o que dá o ritmo binário de sins e nãos. $\mathrm{O}$ crime de Martim, baseado nas idéias da via romântica da liberdade de escolha e da revolta como fundamento de mudança, "culminará na amarga desistência e na resignação muda do final do romance." ${ }^{\text {}}$, diferente do que acontece no fim de PSGH, em que desistir é o prêmio pelo esforço, não é amargo como é para Martim, é "alegria difícil, mas chama-se alegria".

Retomo e sintetizo: o mal nos diferentes textos de Clarice Lispector, como faceta do neutro (semelhante à náusea de Roquetin), surge de diversos modos, entre eles: resultado de uma busca ("O búfalo"), como ação transgressora que guarda parcela de

Estes homens possuiriam uma capacidade superior de entender os processos do mundo, justificando os meios pelos fins. Assim, Raskolnikov teria cometido um crime, segundo as leis dos homens, autorizável por sua condição de homem extraordinário. Desses homens dependeriam as evoluções, as revoluções e as grandes linhas de força do curso da história. Aos demais, ordinários, restaria o cumprimento quase que maquinal das regras.

Após as peripécias que passam pela perspectiva da culpa, da prisão e por pensamentos com tendências paranóicas, o personagem alivia boa parte de suas tensões numa saída místico-religiosa quando começa a ler a Bíblia e a se interessar pelo cristianismo. No entanto, a saída de Raskolnikov guarda um grau de verdade transcendente e metafísica, diferente do que acontece no mistério próprio da matéria (deste mundo aqui) em que se apóia o misticismo clariceano.

Dostoievski, F. Crime e Castigo. São Paulo: Editora 34, 2001.

${ }^{99}$ Martins, G. op.cit., p.143. 
escolha da consciência (o crime de Martim em ME) e como explosão incontrolável e imprevista de energia desconhecida (como em "A Legião estrangeira").

Em PSGH, continuam presentes tanto a via mística quanto a via romântica. Esta última ganha características particulares devido à solidão física da personagem. Ela não está colocada, ao longo do recorte de sua vida narrado, frente a outros personagens ou a agentes sociais exteriores que a julguem. Tampouco seu crime é previsto pelas leis sociais explícitas em que ela se enquadraria. Ela mata uma barata e não uma pessoa. Quanto a se aproximar e mesmo comer da carne proibida dos animais rastejantes, conforme citação bíblica por ela retomada, não há no seu relato indicação de que G.H. se importe racionalmente com estas recomendações, talvez por não se sentir parte do grupo de cristãos que porventura vejam o texto bíblico como tábua prescritiva de comportamentos. Interessase, de outro modo, pela investigação dos fundamentos humanos do veto bíblico. (Submetese a uma moral, enquanto inconsciente disso, mas não tem motivos racionais que a prendam aos preceitos da religião ou a qualquer coisa.)

Eu me sentia imunda como a Bíblia fala dos imundos. Por que foi que a Bíblia se ocupou tanto dos imundos, e fez uma lista dos animais imundos e proibidos? por que se, como os outros, também eles haviam sido criados? E por que o imundo era proibido? Eu fizera o ato proibido de tocar no que é imundo. (PSGH, 71)

O crime, dentre os fatos narrados, se dá em relação a proibições obscuras de uma moral internalizada. Sua relação com a barata desafia seus padrões de ordem, beleza e limpeza, entre tantas outras dimensões idealizáveis possíveis, que são faces de um padrão moral difícil de abandonar. Ao mesmo tempo em que tenta se livrar dos modos préestabelecidos de recortar o mundo, avaliar, significar e sentir, para dar conta de sua experiência com a barata, G.H. discute com as próprias palavras, que são formalizações desses modos pré-estabelecidos. A revolta, própria da via romântica, também se formaliza, no centro das discussões, como a busca pela palavra nova que não se relacione a um sistema fixo (pois, se assim fosse, teria a rigidez da transcendência entre os homens e entre os tempos), palavra que seja circunstancial e fugaz como a experiência. Quando a via romântica é trazida para o domínio da revolta contra a palavra, surge a impossibilidade lógica da palavra que quer ser não-palavra. 
A via romântica liga-se também a uma busca pela palavra adequada e perfeita ${ }^{100}$. Nega-se a palavra, pois ela é sempre expressão da parcialidade e do humano. A experiência completa se dá no âmbito não-humano, no silêncio da existência não significada. $\mathrm{O}$ todo, aqui, não se relaciona com a idéia de um controle exterior ao mundo (transcendente), mas a uma idéia de apreensão da máquina do mundo ${ }^{101}$ pela palavra, aqui mesmo, de modo a produzir experiência e não apenas aludir a ela.

Na outra dimensão, inconciliável com a primeira, a via mística tende o tempo todo para a dissolução da palavra (e de qualquer outra forma) em silêncio. Essa via ganha um valor especial pelo fato de ser enunciada com mais firmeza no momento final do livro, ${ }^{100}$ A palavra, sempre parcial, recorte, quer ser total.

Perfectum - lat. completamente feito.

101 "A Máquina do mundo", de Drummond, e "O Aleph", de Borges, são dois dos inúmeros exemplos da literação de um mecanismo total. No entanto, tais exemplos são menos angustiantes que a totalidade clariceana de G.H., fugidia, fugaz, incompreensível, que se realiza como uma sensação passada, perdida entre os cacos da experiência esboçada em palavra. O Aleph, por exemplo, tem permanência, lugar fixo, determinado, e tem correspondente em imagens objetivas (ao contrário das sensações disformes, paradoxais e inenarráveis de G.H.)

"- Está no porão da sala de jantar. /.../ A escada do porão era empinada, meus tios me tinham proibido descer, mas alguém me falou que havia um mundo no porão." (p.130)

"o lugar onde estão, sem se confundirem, todos os lugares do mundo, vistos de todos os ângulos."

"Já sabes, é indispensável o decúbito dorsal. Também o são a escuridão, a imobilidade, certa acomodação ocular. Tu te encostas no piso de tijolos e fixas o olhar no décimo nono degrau da tal escada." (p.131)

Guarda-se, também, a distância entre sujeito e objeto. O sujeito ainda pode buscar o Aleph, se quiser. Ele está lá à espera, num lugar bem determinado e objetivo. G.H., no entanto, experimenta a totalidade pela indiferenciação que a toma em relação ao mundo, o que apaga as fronteiras entre o eu e o outro.

O problema da descrição do Aleph em palavras também é enfrentado, mas a dificuldade se encontra em descrever o infinito pelo finito, sem que se questione muito a objetividade e a permanência da experiência. $\mathrm{O}$ único senão sobre a capacidade do narrador apresentado por ele mesmo é o paulatino apagamento da memória do objeto.

"Toda linguagem é um alfabeto de símbolos cujo exercício pressupõe um passado que os interlocutores compartem; como transmitir aos outros o infinito Aleph, que minha tímida memória mal e mal abarca?" (p.132)

"Mesmo porque o problema central é insolúvel: a enumeração, sequer parcial, de um conjunto infinito. Neste instante gigantesco, vi milhões de atos agradáveis ou atrozes; nenhum me assombrou mais que o fato de todos ocuparem o mesmo ponto, sem superposição e sem transparência. O que os meus olhos viram foi simultâneo; o que transcreverei será sucessivo, pois a linguagem o é. Algo, entretanto, registrarei." (p.133)

Para G.H., a experiência se dá sem que haja observador isento. O observador está completamente dissolvido no mundo, sua percepção está alterada em relação a seu estado ordinário, a partir do qual fará sua tentativa de descrição.

Borges, J.L. "O Aleph" In: O Aleph. Globo: Porto Alegre, 1973.

Andrade, C.D. "A Máquina do mundo" In: Reunião: 10 livros de poesia. Rio de Janeiro: José Olympio, 1976. 
como a aceitação de que o mundo caminha e de que permanece um mistério independente das ações e buscas humanas ("ação" e "busca" aproximam-se dos métodos da via romântica). Relativiza-se um pouco a superioridade da aceitação em relação à busca pelas induções ao tempo cíclico feitas ao longo do livro, o que faz do fim um instante qualquer, indiferente de qualquer outro momento do texto.

Esta irredutibilidade das duas vias numa só vem desde o título. Este, como um todo, tem a mesma fórmula das paixões bíblicas (Paixão Segundo São João, por exemplo) e, nesta acepção, remete ao caminho de Cristo, que paga pelos pecados de todos os homens com a finalidade de redimir a humanidade. É a alegoria do sofrimento presente com finalidade alheia (alheia tanto por ser feito por outrem quanto por ser feito num momento com conseqüências planejadas, afastadas no tempo em relação a esse momento). Comparada à trajetória enunciativa de G.H., tem afinidade com o sacrifício da palavra cristalizada em nome de um mistério indizível, ou com o sofrimento de não conseguir expressar a experiência pela palavra associado a alguma esperança de comunicar pelas entrelinhas.

$\mathrm{Na}$ tradição filosófica, o $\operatorname{cogito}^{102}$ cartesiano, que funciona como evidência com a qual afirma-se (diferenciando) o homem em relação a tudo o que não é homem, introduz a oposição entre os fatos do mundo e os fatos do homem. Os fatos do mundo obedeceriam a leis necessárias e inapeláveis sem que uma escolha fosse feita. O homem, no entanto, possuiria liberdade e agiria, não segundo leis necessárias, mas de acordo com suas escolhas. Também, elegeria critérios e atrelaria suas escolhas presentes a fins futuros. $\mathrm{O}$ modo como G.H. se apega à via mística exige a negação deste princípio filosófico que postula a liberdade de escolha como característica humana inalienável. No existencialismo sartriano, por exemplo, herdeiro do cogito cartesiano, a liberdade associa-se a um princípio ético em que, na impossibilidade de alienar o homem de sua liberdade, agir como que abrindo mão da escolha é já escolher não escolher, e constitui uma afirmação, ainda que pelo ato localizado, de uma escolha moral.

Em PSGH, quando o enunciado trilha a via mística, a idéia de liberdade parece diferente. Abrir mão da liberdade submetendo-se aos processos do mundo é tido como liberdade de não ter que escolher, e não é em si uma escolha pois essa liberdade em relação à obrigação de escolher não vem do indivíduo mas o toma a partir do exterior. Desse

${ }^{102}$ Cogito ergo sum, Descartes: Penso, logo existo. 
modo, aparece uma segunda acepção da palavra paixão do título do livro. Como muitas vezes é traduzido, o páthos grego tem o sentido de afecção, aquilo que toma o indivíduo de fora para dentro, sem que ele escolha. Para a situação do homem neste momento, tanto em G.H. quanto em alguns outros textos, Clarice Lispector escolhe justamente o nome de "liberdade".

No conto "Perdoando Deus"103, por exemplo, a narradora se apresenta tomada por uma pouco usual sensação de completude. Experimenta sua comunhão com o mundo que apenas existe, e o retrata como um amor materno por Deus, sem posses nem hierarquias entre eu e mundo. Dá a esse estado de comunhão, que aparece sem que ela perceba, o nome de "livre". "Ainda não percebera que na verdade não estava distraída, estava era de uma atenção sem esforço, estava sendo uma coisa muito rara: livre." Sobre sua possibilidade de provocar este estado, nega-a, "Enquanto eu inventar Deus, Ele não existe", o que é paralelo à impossibilidade de avaliar em positivo ou negativo sua experiência, pois do amor materno passa a um estado de ódio quando um grande rato ruivo aparece sob seus pés, também Deus.

Assim, liberdade é uma palavra que aproxima um estado individual, um ponto de vista sobre o mundo. Pode se referir tanto à possibilidade de escolher quanto à nãoobrigação e impossibilidade de escolher. O lugar de fala do narrador expressa um ou outro estado, o que faz com que muito do que se passa em Clarice Lispector esteja sempre próximo de uma catástrofe. Isto significa que um equilíbrio instável determina a liberdade de escolher (e de narrar), podendo a qualquer momento ser afetado por uma causa não controlada e passar do controle sensível ao descontrole inenarrável. Em geral, os elementos que fazem esta transição, em Clarice Lispector, não são grandiosos e desconhecidos, mas ordinários e cotidianos. A instabilidade do equilíbrio que permite caminhar não é visível antes de o descontrole tomar algum personagem, pois não difere, na aparência, do mundo ordinário. $\mathrm{O}$ equilíbrio vem sem se anunciar demais, embora o clima de instabilidade às vezes se anuncie na narrativa.

Eu não sabia que tudo aquilo fazia parte do que ia acontecer. Mil vezes antes o movimento provavelmente começara e depois se perdera. Dessa vez o movimento iria ao fim, e eu não pressentia. (PSGH, 35)

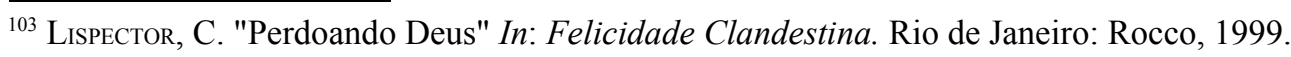


Como diz o narrador de $A$ Náusea no trecho já citado neste capítulo, quando se narra, começa-se sempre pelo fim, o texto todo seleciona os fatos por alguma motivação que já existe. A G.H. que narra sua experiência já passou pelo descontrole e, quando narra, tenta pôr ordem, encontrar encadeamentos lógicos, evidências que não tinha notado no momento ou pouco antes da experiência.

Affonso Romano de Sant'Anna ${ }^{104}$ já havia feito esta aproximação entre PSGH e a Teoria das Catástrofes. A Teoria das Catástrofes se ocupa do estudo de fenômenos físicos instáveis, relaciona-se diretamente com alguns princípios da Teoria do Caos, nos quais pequenas mudanças nas variáveis observadas podem produzir efeitos enormes nos resultados dos fenômenos. Um exemplo simples dessa idéia é o de uma bolinha quicando no piso plano à beira de um abismo. Centímetros para cá, a bolinha continua sob a previsibilidade de um piso plano. Centímetros para lá, a bolinha pode ser levada ao imprevisível do abismo centena de metros abaixo. Este espaço horizontal de poucos centímetros que separa o piso plano e o abismo é o domínio das teorias do Caos e da Catástrofe. Num dos sentidos, nesse plano horizontal, as regras do mundo (causalidade, por exemplo) são bem determinadas e generalizáveis. No outro sentido, o do abismo, a partir de certo momento suspende-se a lógica usual e as possibilidades humanas de escolher.

Aliás, a idéia de queda é bastante ilustrativa para a experiência de G.H. Se o equilíbrio de três pernas é perdido, o que a coloca instável à beira do abismo, a queda catastrófica está pronta para acontecer. Esse é o lugar por excelência de muito dos narradores e personagens clariceanos: próximos de um abismo. Mas o abismo é invisível antes de se cair nele, impossível evitá-lo. Também, durante a queda, não se sai por vontade própria. É como se, mesmo que o personagem estivesse parado, o abismo surgisse sob seus pés. E depois de a queda cessar, a possibilidade de que haja um abismo em qualquer lugar sob o chão firme visível torna-se presente e faz absurda a vida ordinária, visível, relatável e organizada.

No caso de PSGH, uma conjunção difícil de organizar de estados interiores e disposição de objetos, exteriores, todas variáveis usuais da vida da personagem (a barata, o quarto, o horário...), faz com que G.H. seja levada a um mundo distante de seu chão usual previsível ou, pelo menos, controlável.

\footnotetext{
${ }^{104}$ Sant'Anna, A.R. "O Ritual epifânico do texto" In: Lispector, C. A Paixão Segundo G.H. (ed. crítica). Rio de Janeiro: UFRJ, 1996.
} 
Em um mundo assim, em que o equilíbrio controlado pode sofrer, a qualquer momento, uma mudança enorme por fatores imprevisíveis que levam os protagonistas a estados também imprevisíveis, a evidência da contingência e descontrole do mundo pelo homem é muito maior do que em narrativas de equilíbrios mais estáveis. A palavra, para comunicar, exige permanência. No desequilíbrio, permanente é a mudança. Assim, a palavra só pode ser moldada no equilíbrio. Soma-se a isso o fato de que, como já foi comentado nas partes precedentes deste trabalho, a palavra não é apenas expressão de um pensamento mas também o próprio mecanismo de pensar. Assim, a palavra (do controle) torna-se ferramenta pouco adaptada a expressar o descontrole. A permanência de significado exigida à palavra para que comunique não é adequada à expressão do descontrole (que tem enorme potencial de mudança).

Essa visão de mundo, do "mundo grande" que não cabe nas mãos do homem, em que as forças que agem no indivíduo são, em grande parte, devidas a potenciais que não a sua escolha, aproxima Clarice Lispector do existencialismo sartriano, e G.H. de Roquetin (protagonista de A Náusea). Ao longo de todo o romance, termos como "por acaso", "acaso", "vagos", "zumbido", "sem importância" dão a idéia de contingência.

Compreendi então tudo que nos separava: o que eu podia pensar a seu respeito não o atingia: não passava de psicologia como a que se faz nos romances. Mas seu julgamento me trespassava como um gládio e questionava até meu direito de existir. E era verdade, sempre me apercebera disso: não tinha o direito de existir. Surgira por acaso, existia como uma pedra, uma planta, um micróbio. Minha vida se desenvolvia ao acaso e em todos os sentidos. Enviava-me às vezes sinais vagos; outras vezes eu percebia apenas um zumbido sem importância." ${ }^{105}$

O que os afasta, G.H. e Roquetin, no entanto, são a postura de aceitação das contingências de G.H., à qual ela dá o nome de liberdade, e a revolta necessária a deixar evidente a liberdade (consciência) da concepção de mundo de Sartre.

Como último refúgio, o homem sartriano tem sempre o direito de resistir em consciência. Este homem sofre pelo seu inalienável distanciamento do mundo. Pelo mesmo

${ }^{105}$ SARTRe, J.P. A Náusea. Rio de Janeiro: Record, 1997, p.129. 
distanciamento, tem abrigado seu direito de escolha - sua liberdade, poder de escolher, não pode ser afetada pelo mundo. Neste contexto, a náusea em Sartre é a percepção consciente do mundo que existe sem uma intenção (seja moral, seja estética, seja ética etc). Para G.H., sua experiência com a barata também apresenta a contingência do mundo, mas, em vez de a consciência ainda guardar autonomia (liberdade), a percepção de G.H. é provocada por determinação externa. Nesse momento de revelação mística, a consciência da personagem é um olho que vê mas não escolhe. Fora deste espaço-tempo de revelação, pouco ou nada desta experiência é racionalizável, formalizável. Resta o mistério informe, a intuição que nunca é palavra, que talvez (nunca é possível ter certeza), no texto, seja entrelinha. Não é um Eu consciente que se afirma, mas um Eu que some.

\footnotetext{
Para buscar o Eu, o "mim de mim" verdadeiro e essencial, Martim anula e destrói o Outro, sua esposa. Porém, fracassado, retorna ao mundo clicherizado dos outros. G.H. percebe, diferentemente, ser necessário matar o "eu" para alcançar o Eu; somente com a despersonalização - a "violentação de nós mesmos" que conduz à indiferenciação das existências - atingir-se-ia o Ser. ${ }^{106}$
}

Para Roquetin, a revelação da contingência se configura, depois, em afirmação de sua liberdade, já que nenhuma lei existe antes de sua própria escolha. Para G.H., de outro modo, a revelação da contingência, que a toma sem que ela escolha e sem muito se anunciar (de modo semelhante à náusea sartriana), não se afasta demais em momento algum. No mundo formalizado em livro por Sartre, os abismos escondidos são em número bem menor que no mundo de G.H. ou de alguns outros personagens de Clarice Lispector. O lugar de fala dos narradores clariceanos é sempre próximo de abismos onde nenhuma organização existe. Há um diagnóstico semelhante do mundo: o homem livre inserido numa dinâmica de mundo sem intenções acessíveis. Mas Sartre opta por concentrar-se na liberdade e em suas próprias intenções. A Clarice Lispector de PSGH mais aceita algumas determinações do mundo.

\footnotetext{
${ }^{106}$ Martins, G. op. cit., p.168.

Essa citação sugere que o sujeito possa violentar-se e atingir o Ser pelo caminho da escolha. G.H. não é tão positiva a respeito disso. A indiferenciação se daria por afecção (passivamente), não por escolha. A busca não leva à epifania.
} 


\section{Considerações finais antes do silêncio}

No primeiro contato, eu não entendi o livro. Nem muitas perguntas eu tinha sobre ele. Foi depois que apareceram as dúvidas, se a experiência de G.H. tinha produzido mudança na personagem, feito com que ela fosse significativamente diferente, ou apenas diferente; se suas tentativas de dizer a experiência teriam servido apenas para que ela se livrasse do incômodo do informe ou se teriam servido para criar novos moldes para recortar a vida. Como para todas as questões em A Paixão segundo G.H., ainda que eu dissesse sim para alguma opção de resposta, teria que dizer não em seguida. Porque é desse jeito.

Mesmo a alternância de sins e nãos, que pode ser dita constante em todo o livro, se nega porque o livro acaba, em algum lugar há silêncio, que é o oposto do livro. E não há silêncio, porque esse silêncio a que me refiro é já uma idéia de silêncio, uma construção negativa. O silêncio é o que se diz dele, ou o que não se diz dele, dizendo outra coisa. Apreendido, não é mais silêncio.

Dissolver a forma é então simulação de informe. E é preciso depois dissolver a idéia de informe, e depois a idéia de dissolver, e depois a de idéia, e a de depois. Sim não sim não. E, muito antes, a idéia de romance, que enquanto reproduzir modelos não será o novo que poderia soar como experiência e não reprodução a quem o lesse.

O enunciado de G.H. preocupa-se com o dizer mais que com os conteúdos e fatos ditos. É para pôr em evidência a prisão que é a linguagem que ela finge fugir da prisão o tempo todo para depois reconhecer que talvez não tenha fugido mesmo. Mesmo as vias romântica e mística, propostas por Benedito Nunes, só são vias por serem forma. E se os motivos humanos e os motivos do mundo não são o que se diz deles mas, talvez, a tentativa de perdurar, a sobrevivência da espécie e do indivíduo, isso ainda é forma, é modo de ver o mundo, os animais e o homem. Enquanto houver uma explicação, essa não é o mundo.

O ritmo da palavra dita ainda é forma e, se achamos que entendemos alguma coisa, mesmo o ritmo, perdemos a coisa e só o que temos é construção. E se há alguma coisa além desse modo de existir, é algo que não a entrelinha, que já é idéia de entrelinha. É algo que escapa e, difícil de entender, a gente às vezes ainda crê na sua existência. 
A liberdade buscada numa forma menos fóssil e mais fluida é tão palavra quanto a liberdade de não precisar escolher. O modo de o homem ser especificamente humano pode ser tanto expressão de uma liberdade como de uma imposição do mundo. Essa dúvida se afirma tanto no enunciado de G.H. que a impede de dizer muito mais que o silêncio. Ao mesmo tempo, para negar o sim anterior, o não-dizer, G.H. diz.

Do lugar de fala de G.H., não é possível escolher revoluções coletivas. Talvez paralisações coletivas. G.H., se percebesse alguma vez ser prescritiva, prescreveria logo um contrário, ou um nada. Escolhe, no máximo, a cor do próprio vestido e um lugar onde passará a noite. $\mathrm{O}$ espaço e o tempo presentes não permitem maior expansão. A desistência como prêmio é fazer um sim pouco maior, que dure uma noite talvez, antes do próximo não. 


\section{BIBLIOGRAFIA}

* Recomendo, para bibliografia mais extensa e análise da fortuna crítica d'A Paixão segundo G.H.:

Amaral, Emília. O Leitor segundo G.H. Cotia/SP: Ateliê, 2005.

\section{De Clarice Lispector}

A Descoberta d o mundo. Rio de Janeiro: Rocco, 1999.

A Hora da estrela. Rio de Janeiro: Rocco, 1998.

A Legião estrangeira. Rio de Janeiro: Rocco, 1999.

A Maçã no escuro. Rio de Janeiro: Rocco, 1999.

A Paixão segundo G.H. Rio de Janeiro: Rocco, 1998.

Água viva. Rio de Janeiro: Rocco, 1999.

Felicidade clandestina. Rio de Janeiro: Rocco, 1999.

Laços de família. Rio de Janeiro: Rocco, 1999.

\section{Sobre Clarice Lispector}

Amaral, Emília. O Leitor segundo G.H. Cotia/SP: Ateliê, 2005.

Borelli, Olga. Clarice Lispector: esboço para um possível retrato. Rio de Janeiro: Nova Fronteira, 1981.

Candido, Antonio. No Raiar de Clarice Lispector. In Vários Escritos. São Paulo: Duas Cidades, 1970.

. Uma tentativa de Renovação. In Brigada Ligeira. São Paulo:

Martins, 1945.

GotLiB, N.B. Clarice - Uma vida que se conta. São Paulo: Ática, 1995.

Hansen, J.A. "Uma estrela de mil pontas" In: Língua e Literatura (17), São Paulo, 1989, pp.107-122.

KaHn, D.M. A via crúcis do outro: aspectos da identidade e da alteridade na obra de Clarice Lispector. São Paulo: FFLCH/USP, 2000 (dissertação de mestrado).

Lispector, C. A Paixão Segundo G.H. (ed. crítica). Rio de Janeiro: UFRJ, 1996.

Martins, G.F. As Vigas de um heroismo vago: três estudos sobre A Maçã no escuro". São Paulo: FFLCH/USP, 1997 (dissertação de mestrado).

- Alter(c)idades - um exercício de escalas (espaço público, modos de

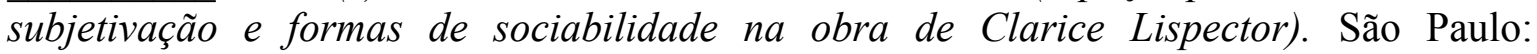
FFLCH/USP, 1997 (tese de doutorado). 
Nunes, Benedito. O Drama da linguagem: uma leitura de Clarice Lispector. São Paulo: Ática, 1989.

Amazonas, 1966.

O Mundo de Clarice Lispector. Manaus, Governo do Estado - O Mundo Imaginário de Clarice Lispector. In: O Dorso do Tigre. São Paulo: Perspectiva, 1969 (Ensaios).

Rosenbaum, Y. Metamorfoses do Mal. São Paulo: Edusp, 1999.

SÁ, Olga de. Clarice Lispector: Processos Criativos. Pittsburg: Iberoamericana, 1984. . A Escritura de Clarice Lispector. Petrópolis: Vozes,1979.

Sant'Anna, Afonso Romano de. A Leitura de Clarice. Rio de Janeiro: Littera, 1973.

Waldman, Berta. Clarice Lispector. A Paixão segundo Clarice Lispector. São Paulo: Brasiliense, 1983.

\section{Geral}

Adorno, T. "Lírica e Sociedade", In: Os Pensadores v. 38. São Paulo: Abril Cultural, 1980. "A Posição do narrador no romance contemporâneo ", In: Os Pensadores v. 38. São Paulo: Abril Cultural, 1980.

Andrade, C.D. "A Máquina do mundo" In: Reunião: 10 livros de poesia. Rio de Janeiro: José Olympio, 1976.

Aristóteles Poética. Porto Alegre, Globo, 1966.

Arrigucci JR., D. O Escorpião Encalacrado. São Paulo: Perspectiva, 1995.

Bergson, Henri A Intuição Filosófica. Lisboa, Colibri, 1994.

Borges, J.L. "O Sul" In:Ficções. Globo: Rio de Janeiro, 1984. . "O Aleph" In: O Aleph. Globo: Porto Alegre, 1973.

CARrière, J.C. A Linguagem secreta do cinema. Rio de Janeiro: Nova Fronteira, 1995.

Cortázar, Julio Obra Crítica (3 volumes). Rio de Janeiro: Civilização Brasileira, 1998. . Bestiário. Nova Fronteira, 1986. 
. O Jogo da Amarelinha. Rio de Janeiro: Civilização Brasileira, 1999.

. Prosa do Observatório. São Paulo: Perspectiva, 1974.

. Valise de Cronópio. São Paulo, Perspectiva, 1974.

Dostoievski, F. Crime e Castigo. São Paulo: Editora 34, 2001.

Forster, E.M. Aspectos do Romance. Porto Alegre, Globo, 1969.

Freud, S. "O porvir de uma ilusão" In: Os Pensadores: Freud (v.39). São Paulo: Abril Cultural, 1978.

"O Mal-estar na civilização" In: Os Pensadores: Freud (v.39). São Paulo: Abril Cultural, 1978.

Heidegger, M. "Tempo e Ser", In: Os Pensadores. São Paulo: Abril Cultural, 1980.

KafKa, F. A Metamorfose. São Paulo: Companhia das Letras, 2000.

Mann, Thomas. “A Arte do romance” In: Ensaios. São Paulo: Perspectiva , 2000.

Melo Neto, J.C. Agrestes. Rio de Janeiro: nova Fronteira, 1985.

Mendilow, A.A. O Tempo e o Romance. São Paulo, Cultrix/EDUSP, 1974.

PASta JR., J.A. "O Romance de Rosa - temas do Grande sertão e do Brasil". In: Novos Estudos - CEBRAP n.55, nov. 1999, pp.61-70.

PAz, O. O Arco e a lira. Rio de Janeiro: Nova Fronteira, 1982.

Rosenfeld, Anatol "Reflexões sobre o romance moderno". In: Texto/Contexto. São Paulo, Perspectiva, 1971.

SARtre, Jean-Paul. A Náusea. Rio de Janeiro/São Paulo: Record/Atalaya, 1997. Que é Literatura. São Paulo: Ática, 1999. . O Ser e o Nada. Petrópolis: Vozes, 2000.

Wittgenstein, L. Investigações Filosóficas. São Paulo: Abril Cultural, 1984.

Wittgenstein, L. Tractatus Logico-Philosophicus. São Paulo: Nacional, 1968. 